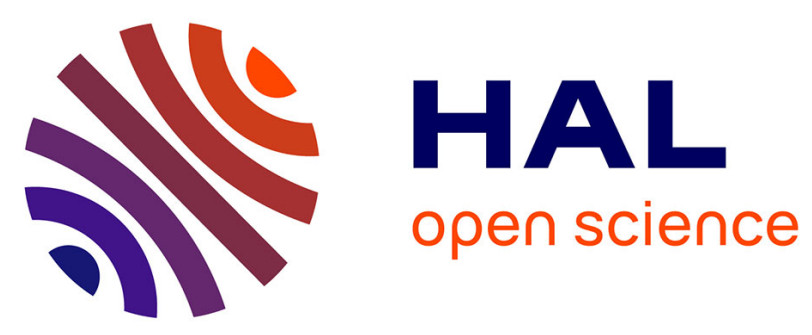

\title{
Magmatism and crustal extension: Constraining activation of the ductile shearing along the Gediz detachment, Menderes Massif (western Turkey)
}

Frederico Rossetti, Riccardo Asti, Claudio Faccenna, Axel Gerdes, Frederico Lucci, Thomas Theye

\section{To cite this version:}

Frederico Rossetti, Riccardo Asti, Claudio Faccenna, Axel Gerdes, Frederico Lucci, et al.. Magmatism and crustal extension: Constraining activation of the ductile shearing along the Gediz detachment, Menderes Massif (western Turkey). Lithos, 2017, 282-283, pp.145-162. 10.1016/j.lithos.2017.03.003 . insu-01488903

\section{HAL Id: insu-01488903 \\ https://hal-insu.archives-ouvertes.fr/insu-01488903}

Submitted on 14 Mar 2017

HAL is a multi-disciplinary open access archive for the deposit and dissemination of scientific research documents, whether they are published or not. The documents may come from teaching and research institutions in France or abroad, or from public or private research centers.
L'archive ouverte pluridisciplinaire HAL, est destinée au dépôt et à la diffusion de documents scientifiques de niveau recherche, publiés ou non, émanant des établissements d'enseignement et de recherche français ou étrangers, des laboratoires publics ou privés. 


\section{Accepted Manuscript}

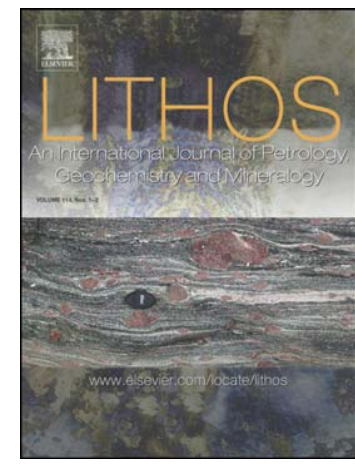

Magmatism and crustal extension: Constraining activation of the ductile shearing along the Gediz detachment, Menderes Massif (western Turkey)

Federico Rossetti, Riccardo Asti, Claudio Faccenna, Axel Gerdes, Federico Lucci, Thomas Theye

PII: $\quad$ S0024-4937(17)30089-0

DOI: $\quad$ doi: $10.1016 /$ j.lithos.2017.03.003

Reference: $\quad$ LITHOS 4252

To appear in: $\quad$ LITHOS

Received date: $\quad 4$ July 2016

Accepted date: $\quad 3$ March 2017

Please cite this article as: Rossetti, Federico, Asti, Riccardo, Faccenna, Claudio, Gerdes, Axel, Lucci, Federico, Theye, Thomas, Magmatism and crustal extension: Constraining activation of the ductile shearing along the Gediz detachment, Menderes Massif (western Turkey), LITHOS (2017), doi:10.1016/j.lithos.2017.03.003

This is a PDF file of an unedited manuscript that has been accepted for publication. As a service to our customers we are providing this early version of the manuscript. The manuscript will undergo copyediting, typesetting, and review of the resulting proof before it is published in its final form. Please note that during the production process errors may be discovered which could affect the content, and all legal disclaimers that apply to the journal pertain. 
Magmatism and crustal extension: constraining activation of the ductile

shearing along the Gediz detachment, Menderes Massif (western Turkey)

Federico Rossetti ${ }^{1, *}$, Riccardo Asti ${ }^{2}$, Claudio Faccenna ${ }^{1}$, Axel Gerdes ${ }^{3}$, Federico Lucci ${ }^{1}$, Thomas Theye ${ }^{4}$

${ }^{1}$ Dipartimento di Scienze, Università Roma Tre, Roma, Italia

${ }^{2}$ Géosciences Rennes, UMR 6118, Université de Rennes 1, Rennes, France

${ }^{3}$ Institut für Geowissenschaften, Goethe-Universität, Frankfurt am Main, Germany

${ }^{4}$ Institut für Mineralogie und Kristallchemie, Universität Stuttgart, Stuttgart, Germany

*Corresponding Author:

Dipartimento di Scienze, Sezione Scienze Geologiche - Università Roma Tre largo Sann Leonardo Murialdo, 1

00146 Roma (Italy)

email: federico.rossetti@uniroma3.it

tel: +390657338043 


\section{Abstract}

The Menderes Massif of western Turkey is a key area to study feedback relationships between magma generation/emplacement and activation of extensional detachment tectonics. Here, we present new textural analysis and in situ $\mathrm{U}-(\mathrm{Th})-\mathrm{Pb}$ titanite dating from selected samples collected in the transition from the undeformed to the mylonitized zones of the Salihli granodiorite at the footwall of the Neogene, ductile-to-brittle, top-to-the-NNE Gediz-Alaşheir (GDF) detachment fault. Ductile shearing was accompanied by the fluid-mediated sub-solidus transformation of the granodiorite to orthogneiss, which occurred at shallower crustal levels and temperatures compatible with the upper greenschist-to-amphibolite facies metamorphic conditions (530-580 ${ }^{\circ} \mathrm{C}$ and $\left.\mathrm{P}<2 \mathrm{GPa}\right)$. The syn-tectonic metamorphic overgrowth of REE-poor titanite on pristine REE-rich igneous titanite offers the possibility to constrain the timing of magma crystallisation and solid-state shearing at the footwall of the Gediz detachment. The common $\mathrm{Pb}$ corrected ${ }^{206} \mathrm{~Pb} /{ }^{238} \mathrm{U}\left({ }^{206} \mathrm{~Pb} * /{ }^{238} \mathrm{U}\right)$ ages and the REE re-distribution in titanite that spatially correlates with the $\mathrm{Th} / \mathrm{U}$ zoning suggests that titanite predominantly preserve opensystem ages during fluid-assisted syn-tectonic re-crystallisation in the transition from magma crystallization and emplacement (at $\sim 16-17 \mathrm{Ma}$ ) to the syn-tectonic, solid-state shearing (at $\sim 14$ Ma). A minimum time lapse of ca. 1-2 Ma is then inferred between the crustal emplacement of the Salihli granodiorite and nucleation of the ductile extensional shearing along the Gediz detachment. The reconstruction of the cooling history of the Salihli granodiorite documents a punctuated evolution dominated by two episodes of rapid cooling, between $\sim 14 \mathrm{Ma}$ and $\sim 12 \mathrm{Ma}$ $\left(\sim 100{ }^{\circ} \mathrm{C} / \mathrm{Ma}\right)$ and between $\sim 3$ and $\sim 2 \mathrm{Ma}\left(\sim 105^{\circ} \mathrm{C} / \mathrm{Ma}\right)$. We relate the first episode to nucleation and development of post-emplacement of ductile shearing along the GDF and the second to brittle high-angle faulting, respectively. Our dataset suggests that in the Menderes Massif the activation of ductile extension was a consequence, rather than the cause, of magma emplacement in the extending crust. 
Key words: extensional tectonics; magmatism; mylonite shearing; thermobarometry; U-Pb geochronology; Menderes Massif; Turkey

\section{Highlights}

-Solid-state ductile shearing is described at the footwall of the Gediz detachment

-Polyphase titanite growth records transition from granodiorite to orthogneiss formation.

-Solid-state shearing postdates of ca. 1-2 Ma magma emplacement in the extending crust.

- Crustal ductile extension is the consequence rather than the cause of magma emplacement 


\section{Introduction}

Detachment faults are high-strain, ductile-to-brittle, low-angle extensional shear zones, typically constituted by an upper cataclastic or ultracataclastic horizon, underlain by a ductile, hundreds of meters thick, mylonitic to ultramylonitic zone (e.g. Lister and Davis, 1989). When exposed at the surface, these shear zones generally separate a non-metamorphosed or slightly metamorphosed hanging wall, from a higher grade metamorphic footwall, also known as metamorphic core complexes (e.g. Crittenden et al., 1980; Davis and Coney, 1989; Davis et al., 2004; Gautier and Brun, 1994; Jolivet et al., 2004; Lister et al., 1984; Wernike, 1985; Whitney et al., 2013 and references therein). The role of magmatism in core complex formation and, more in general, in the activation of ductile extensional tectonics is still debated. In particular, it is a key issue to understand whether is magmatism that facilitates detachment faulting (and core complex formation in general) or the other way around, because despite extension-driven decompression may cause melting, melting itself may promote and guide the extensional process (e.g. Corti et al., 2003; Laurent et al., 2015; Parson and Thompson 1993; Teyssier and Whitney, 2002; Whitney et al., 2013). In particular, crustal heating induced by pluton emplacement at shallow depths may generate a time-dependent variation in the rheological properties of the crust by causing an upward migration of the (regional) brittle-ductile transition and allowing shear strain localization facilitated by thermal softening (Caggianelli et al., 2013; Jolivet and Patriat, 1999; Lister and Baldwin, 1993; Rabillard et al., 2015). The thermal softening induced by magmatism may also facilitates the slip on low-angle normal faults by inducing rotation of the principal stresses (Parsons and Thompson, 1993). As a matter of fact, the general chronological relationship between the onset of extension and magmatism is not straightforward: it has been documented that one can alternatively pre-date the other, or these may even be synchronous (e.g. Aoya et al., 2005; Jolivet and Brun, 2010; Laurent et al., 2015; Lister and Baldwin, 1993; Metcalf and Smith, 1995; Rabillard et al., 2015).

The Menderes Massif of western Turkey (Fig. 1) is a key area to study feedback relationships between Neogene magma generation/emplacement and activation of extensional detachment tectonics (Bozkurt and Park, 1994; Çemen et al., 2006; Dilek et al., 2009; Erkül et 
al., 2013; Glodny and Hetzel, 2007; Hetzel et al., 1995a,b; Işik et al., 2003; Öner et al., 2010;

Ring et al., 1995; Ring and Collins, 2005; Thomson and Ring, 2006). Pluton emplacement is commonly considered as syn-extensional (e.g. Dilek et al., 2009; Erkül et al., 2013 and references therein; Işik et al., 2003), but some uncertainty still persists on the timing of magma crystallization and ductile shearing (Catlos et al., 2010; 2011).

In this study, we report new mineralogical, petrographical observations and in situ U(Th)-Pb titanite geochronology results from selected samples collected in the transition from the undeformed to the mylonitized zones of the early Miocene Salihli granodiorite at the footwall of the Gediz-Alaşheir detachment fault (Hetzel et al., 1995a; Işik et al., 2003; Figs. 1 and 2; hereafter referred as GDF), documenting a minimum time lapse of ca. 1-2 Ma between magma crystallization/emplacement and activation of ductile shearing associated with the development of the GDF. We conclude that the Neogene extensional detachment tectonics was a consequence, rather than the cause, of magma emplacement in the Menderes Massif.

\section{Geological background}

The Menderes Massif of western Turkey (Fig. 1) is an Alpine extensional province, which has been affected by post-orogenic crustal stretching since the Oligocene-Miocene times as a part of the Tertiary Aegean extensional system (e.g. Gessner et al., 2001a; Jolivet et al., 1994; 2010; Jolivet and Brun, 2010; Ring et al., 2003; Thomson and Ring, 2006). The Menderes Massif consists of continental-derived basement nappes, currently interpreted as a metamorphic core complex (Menderes Metamorphic Core Complex, MMCC), whose exhumation was dominantly assisted by ductile-to-brittle extensional detachment tectonics and closely associated with emplacement of syn-tectonic granitoids and formation of supradetachment basins (Bozkurt and Park, 1994; Bozkurt and Sözbilir, 2004; Dilek et al., 2009; Erkül et al., 2013; Glodny and

Hetzel, 2007; Hetzel et al., 1995a,b; Işık et al., 2003; Öner et al., 2010; Öner and Dilek, 2011; Thomson and Ring, 2006). 
Indeed, the activity of the extensional detachment tectonics in the MMCC is chiefly

constrained by the age of crystallization and cooling of the syn-extensional magmatism in the immediate footwall of the detachment faults. In particular, a two-stage extensional detachment tectonics has been reconstructed (Çemen et al., 2006). The early stage is associated with the activity of the early Miocene ( 21-19 Ma) top-to the-N Simav detachment in the northern part of the Menderes Massif, as constrained by the syn-tectonic Alaçamdağ magmatic suite (Bozkurt and Satır, 2000; Erkül and Erkül, 2010; Işik et al., 2003; Ring and Collins, 2005). The second stage is associated with the middle Miocene activity of the north-dipping Gediz and the southdipping Büyük Menderes detachment faults, associated with the emplacement and ductile shearing of the Salihli and Turgutlu granodiorites in the central part of the Menderes Massif (Glodny and Hetzel, 2007; Hetzel et al., 1995; Lips et al., 2001) (Figs. 1 and 2). Geochemical signatures of the syn-tectonic granitoids document for I- and S-type magmatism, derived from heterogeneous sub-continental lithospheric mantle sources (Catlos et al., 2010; Dilek et al., 2009; Erkül and Erkül, 2012; Erkül et al., 2013; Oner et al., 2010) with a strong crustal fingerprint (Altunkaynak et al., 2012). Igneous thermobarometry documents shallow crustal emplacement conditions for the Miocene granitoids, with crystallization temperatures ranging $700-800^{\circ} \mathrm{C}$ over 0.2-0.3 GPa (Catlos et al, 2010; Erkül et al., 2013).

The Miocene Turgutlu and Salihli granitoids outcrop at the footwall of the NNE dipping GDF (e.g. Erkül et al., 2013; Glodny and Hetzel, 2007; Hetzel et al., 1995a; Işik et al., 2003), a ductile-to-brittle gently dipping $\left(\sim 20^{\circ}\right)$ extensional fault that separates the crystalline rocks of the MMCC at the footwall, from the supradetachment Neogene deposits of the Gediz Graben at the hanging wall (e.g. Gessner et al., 2001a; Hetzel et al., 1995a,b; Işik et al., 2003; Öner and Dilek, 2011) (Fig. 2). The crystallization age of these granodioritic intrusions is constrained to the middle Miocene, based on TIMS U-Pb dating of monazite $(16.1 \pm 0.2 \mathrm{Ma}$; Turgutlu) and allanite (15.0 $\pm 0.3 \mathrm{Ma}$; Salihli) aliquots (Glodny and Hetzel, 2007). The ${ }^{40} \mathrm{Ar} /{ }^{39} \mathrm{Ar}$ biotite ages of

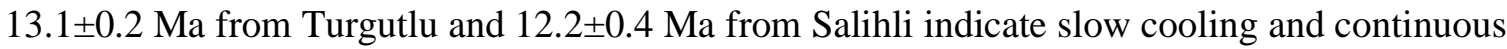
deformation to the late Miocene (Glodny and Hetzel, 2007; Hetzel et al., 1995a,b). A relatively wide range of ages spanning between $21.7 \pm 4.5$ and $9.6 \pm 1.6 \mathrm{Ma}$ was obtained through in situ 
ion microprobe monazite $\mathrm{Th}-\mathrm{Pb}$ dating from the Salihli granodiorite (Catlos et al. 2008, 2010).

The youngest among these ages, obtained from a monazite grain located in the outer edge of an altered plagioclase crystal, was interpreted as a deformation age, rather than a crystallization age, also suggesting that this range of ages most likely dates episodes of deformation and tectonic exhumation (Catlos et al., 2010). ${ }^{40} \mathrm{Ar} /{ }^{39} \mathrm{Ar}$ dating of syn-kinematic white micas from the top of the detachment fault zone yielded ages of $7 \pm 1$ Ma (Lips et al., 2001), interpreted as the time when the shear zone crossed the brittle-ductile transition (Glodny and Hetzel, 2007). Finally, low-temperature thermochronology data (zircon (ZFT) and apatite (AFT) fission track and zircon (ZHe) and apatite (AHe) U-Th/He dating) on the Salihli granodiorite at the footwall of the GDF documents a Messinian-Pliocene (starting at c. 4-6 Ma) event of rapid cooling, slowing down after 2 Ma (Buscher et al., 2013).

For what concerns the upper-plate of the GDF, the sedimentary record of the Gediz Graben indicates that activity of the GDF was pulsed and hence the region experienced episodes of pulsed extension (Bozkurt and Sözbilir, 2004; Purvis and Robertson, 2005). Recently, new detrital AFT ages are made available from the basal sedimentary sequences filling the Gediz Graben, which provided central ages of $16 \pm 1.4 \mathrm{Ma}$ (Asti et al., 2016). This evidence attests that Middle Miocene is the maximum age for the beginning of sedimentation in the Gediz Graben, as already suggested by Çiftçi and Bozkurt (2009).

\section{Methods}

To constrain the age of activation of ductile shearing along the GDF, textural and petrographic observations were carried out in selected S-L tectonites developed at the expenses of the Salihli granodiorite and sampled along a structural transect running sub-parallel to the main NE-trending stretching direction (Fig. 2). Representative samples were chosen for the U-

(Th)- $\mathrm{Pb}$ geochronological study in order to constrain timing of the ductile shear strain along the GDF in the transition from magma crystallization to solid-state shearing. Sample selection was based on the structure at the outcrop scale and on meso- and micro-scale textural and 
mineralogical features. Samples are shown in their structural context in Figure 2 and listed in

Table 1, where their location, fabrics, and constituent mineralogy are detailed. Electron microprobe analyses (EMPA) were used to define compositions of the constituent mineral assemblages.

Details on the analytical methods and protocols adopted in this study are provided in the Appendix. Mineral compositions and representative chemical formulae are provided in the supplementary material. In the following, mineral abbreviations are after Whitney and Evans (2010).

\section{Structures, textures and petrography}

The GDF is exposed over an along-strike distance of more than $80 \mathrm{~km}$ along the southern margin of the Gediz graben, where it consists of a NNE dipping, flat-lying ( $10^{\circ}$ to $\left.30^{\circ} \mathrm{dip}\right)$ ductile-to-brittle shear zone with variable thickness (generally not exceeding 100 m) (Figs. 1 and 2). Eastward, the shear zone bends NS, striking sub-parallel to the main stretching direction (Fig. 2b). The shear zone formed at the expenses of the Miocene Salihli granodiorite and consists of a basal (up to $50 \mathrm{~m}$ thick) mylonite that gradually transition upward into cataclastic and ultracataclasitic fault rocks (Buscher et al., 2013; Catlos et al., 2011; Hetzel et al., 1995a; Işik et al., 2003). Shear sense criteria systematically point to top-to-the-NNE (i.e. dip-slip) sense of shear, in a continuum from ductile-to-brittle deformation conditions (see also Buscher et al., 2013; Hetzel et al., 1995a; Işik et al., 2003).

The study area corresponds to the south-eastern portion of the GDF (Figs. 1 and 2). Our samples are from the high strain domains (Fig. 2c), corresponding to the protomylonitic (T14-09) and mylonitic (T14-06, T14-08 and T14-10) zones. At the meso-scale, protomylonites consist of light, medium-to-fine-grained rocks typified by variably-developed secondary, sub-horizontal foliation outlined by quartz-biotite folia with variable proportions of feldspar porphyroclasts (Fig. 3a). Igneous textures are commonly well preserved. Magmatic mineralogy (see Table 2a-d for representative mineral compositions) consists of $\mathrm{Kfs}\left(\mathrm{X}_{\mathrm{Or}} 90-94 \%, \mathrm{X}_{\mathrm{An}}<2 \%\right)+\mathrm{Pl}_{1}+\mathrm{Qz}+$ 
$\mathrm{Amp}_{1}+\mathrm{Bt}_{1}$ and $\mathrm{Ttn}_{1}, \mathrm{All}$, Ap, Ilm (up to $3 \%$ in vol.) and minor $\mathrm{Zrc}$ as accessory minerals (Fig.

3b). In the mylonitic zone, ductile shearing is responsible for the transformation of the original igneous texture into a plano-linear gneissic fabric ( $\mathrm{S}-\mathrm{L}$ tectonite), outlined by C-type shear bands (e.g. Berthé et al., 1979; Gapais, 1989; Passchier and Trouw, 2005) and pronounced porphyroclastic appearance (Fig. 4a). The stretching lineations attitude is dip-parallel and they are provided by Qz-Fsp-Bt \pm Amp aggregates, trending between $\mathrm{N} 20^{\circ} \mathrm{E}$ and $\mathrm{N} 40^{\circ} \mathrm{E}$ (Fig. $2 \mathrm{a}$ ). At the thin sections scale, shear foliation is defined by the preferred orientation of ribbon Qz, secondary plagioclase $\left(\mathrm{Pl}_{2}\right)$, amphibole $\left(\mathrm{Amp}_{2}\right)$ and biotite $\left(\mathrm{Bt}_{2}\right)$, that together with $\mathrm{Ep}\left(\mathrm{X}_{\mathrm{Fe}}\right.$ $\left.\left[\mathrm{Fe}^{3+} /\left(\mathrm{Fe}^{3+}+\mathrm{Al}^{3+}\right)\right]=0.14-0.17\right)$ and secondary titanite $\left(\mathrm{Ttn}_{2}\right)$ define penetrative oblique foliations with respect to $\mathrm{C}$ surfaces (Fig. 4). Tectonic foliations wrap around Fsp porphyroclasts to produce augen, which typically show a $\sigma$-type geometry with the sense of shear indicating topto-the-NNE (Figs. 3b-d). Ttn 1 grains also form $\sigma$-shaped porphyroclasts and occurs as boudinaged and stretched grains within the shear foliation (Fig. 4c). Feldspar porphyroclasts commonly show recrystallized grains at their boundaries, producing a core-and-rim structure diagnostic of dynamic recrystallization, compatible with medium- to high-grade temperature conditions $\left(600-400{ }^{\circ} \mathrm{C}\right)$ during deformation (e.g., Gapais, 1989; Leloup et al., 1995; Passchier and Trouw, 2005). Myrmekite growth along the boundaries of K-Fsp porphyroclasts and albite flame pertites suggests a fluid-assisted deformation under medium-grade temperature conditions (400-600 ${ }^{\circ} \mathrm{C}$ ) (Menegon et al. 2006; Passchier and Trouw, 2005). Albite-rich $\mathrm{Pl}_{2}$ also commonly occur as rims of $\mathrm{Pl}_{1}$ (Fig. 4d). Bent twin lamellae, undulose extinction, and microfracturing suggest deformation under lower-grade temperature conditions $\left(300-400{ }^{\circ} \mathrm{C}\right.$; e.g., Passchier and Trouw, 2005) (Fig. 4d). Quartz shows dynamic recrystallization, dominantly assisted by subgrain rotation that resulted in pronounced grain size reduction (average grain size of $20 \mu \mathrm{m}$ in the higher strain domains). Healed textures are also observed with evidence of static recrystallization accommodated by grain boundary migration (Figs. 4b-d). These structures are typical at medium- to high-grade conditions $\left(600-400{ }^{\circ} \mathrm{C}\right.$; Drury and Urai; 1990; Hirth and Tullis, 1992; Passchier and Trouw, 2005; Stipp et al., 2002). Quartz grains also exhibit undolose extinction 
and subgrain formation typical of strain-enhanced low-grade conditions (below $300{ }^{\circ} \mathrm{C}$;

Passchier and Trouw, 2005). Igneous biotite and amphibole porpyroclasts usually form asymmetric "fishes" aligned along the stretching lineation (Fig. 4f). Primary $\mathrm{Bt}_{1}$ also shows undolose extinction and, in some samples, kink folding, attesting for deformation temperature below $250{ }^{\circ} \mathrm{C}$ (Passchier and Trouw, 2005).

Igneous plagioclase is characterized by anorthite-rich cores $\left(X_{A n} 43-66 \%\right)$, showing both patchy and oscillatory compositional zoning, affected by corrosion and cracking (see also Catlos et al., 2011). Outer cores consists of $X_{A n} 31-35 \%$, rimmed by thin albite-rich $\left(X_{A n} 25-26 \%\right)$ overgrowth $\left(\mathrm{Pl}_{2}\right)$. Igneous $\mathrm{Bt}_{1}$ is distinctly richer in $\mathrm{TiO}_{2}(1.21-3.016 \mathrm{wt} \%)$ than $\mathrm{Bt}_{2}(0.29-1.05$ wt\%). Two population of amphiboles are identified. Primary (igneous) amphiboles $\left(\mathrm{Amph}_{1}\right)$ show $\mathrm{SiO}_{2}$ in the range 48.50-49.71 wt $\%, \mathrm{Al}_{2} \mathrm{O}_{3}$ 5.34-5.90 wt \% (with $\mathrm{Al}^{\text {tot }}$ 0.94-1.04), and $\mathrm{TiO}_{2}$ 0.62-0.68 wt\%, corresponding to Mg-hornblende (Leake et al., 2004) compositions. Secondary amphibole $\left(\mathrm{Amph}_{2}\right)$, show higher $\mathrm{SiO}_{2}(50.84-51.62 \mathrm{wt} \%)$, lower $\mathrm{TiO}_{2}(0.18-0.25 \mathrm{wt} \%)$ and total $\mathrm{Al}$ always minor than 0.81 , corresponding to actinolite (Leake et al., 2004) compositions.

\section{Titanite microtextures and chemistry}

Ttn makes up up to $1-2 \%$ of the rock and shows evidence of a polyphase crystallization, in a continuum from magma crystallization to solid-state, syn-metamorphic shear zone nucleation and development. Magmatic $\operatorname{Ttn}_{1}$ occurs as isolated grains with euhedral, rhomboid to elongate and rounded shapes (300-500 $\mu \mathrm{m}$ across; Fig. 3b and 5a). Magmatic origin is indicated by: (i) equilibrium textures with recrystallized magmatic Fsp-Qz-Amp-Bt assemblages (Figs. 3b and 5a-b); (ii) Ttn ${ }_{1}$ inclusion in igneous Fsp and Amp $\mathrm{Am}_{1}$ (iii) bright oscillatory and sector zoning in back-scattered electron (BSE) imaging (cfr. Wintsch et al., 2005) (Fig. 5c); and (iv) the pre-kinematic crystallisation relative to the shear foliation (Figs. $4 \mathrm{~d}$ and $5 \mathrm{~b}$ ).

Metamorphic $\operatorname{Ttn}_{2}$ occurs within metamorphic foliation both as minute subhedral grains (10-30 $\mu \mathrm{m}$ across) associated and intergrowth with metamorphic Ep and fabric-forming secondary $\mathrm{Bt}_{2}$ as the replacement products of igneous $\mathrm{Bt}_{1}$ and $\mathrm{Amp}_{1}$ in conjunction with Ep during syn-tectonic 
re-crystallisation (Fig. 5d). Metamorphic $\operatorname{Ttn}_{2}$ also occurs as overgrowth onto magmatic $\operatorname{Ttn}_{1}$ as

outlined by uniform dark grey BSE domains that truncate oscillatory zoning patterns (Fig. 5c).

The two titanites types are chemically distinct (see Table 2d; Figs. 5e-f). The $\operatorname{Ttn}_{1}$ grains systematically show elevated contents of $\mathrm{Y}_{2} \mathrm{O}_{3}(1.02-2.45 \mathrm{wt} \%)$ and $\Sigma \mathrm{REE}(1.05-2.30 \mathrm{wt} \%)$, low $(\mathrm{Ce} / \mathrm{Nd})_{\mathrm{N}}(0.30-0.66$, REE-Chondrite normalization after Sun and McDonough, 1989) and high $(\mathrm{Y} / \mathrm{Nb})_{\mathrm{N}}(0.32-1.59$, Primitive Mantle normalization after McDonough et al., 1991), in conjunction with higher values of $\mathrm{Th} / \mathrm{U}\left(0.70-1.23\right.$; see below). $\operatorname{Tt}_{2}$ composition presents $\mathrm{Y}_{2} \mathrm{O}_{3}$ $(0.0-0.76 \mathrm{wt} \%)$ and $\Sigma \mathrm{REE}(<0.70 \mathrm{wt} \%)$, with low $(\mathrm{Y} / \mathrm{Nb})_{\mathrm{N}}(0.0-0.44)$ values, and lower $\mathrm{Th} / \mathrm{U}$ (0.05-0.69; see below). The $\mathrm{Zr}$ content is high (up to 0.04 wt. $\% \mathrm{ZrO}_{2}$ ) in $\mathrm{Ttn}_{1}$, whereas in $\mathrm{Ttn}_{2}$, either as overgrowth or matrix grains, it is below detection limit of the microprobe. Finally, the $\mathrm{Ttn}_{1}$ generation usually shows higher contents of $\mathrm{Al}_{2} \mathrm{O}_{3}$ and $\mathrm{Fe}_{2} \mathrm{O}_{3}$ compared to $\mathrm{Ttn}_{2}$, but this pattern is not systematically observed. This is at odds with the observation of Wintsch et al. (2005), who measured systematically lower Al contents in the igneous cores compared to metamorphic rims.

\section{P-T conditions of shearing}

The studied mylonitic shear zone developed at subsolidus conditions after crystallization of the Salihli granodiorite, at temperatures below 700-800 ${ }^{\circ} \mathrm{C}$ (Catlos et al., 2010; Erkül et al., 2013). The syn-kinematic assemblage made of $\mathrm{Bt}_{2}-\mathrm{Qz}-\mathrm{Pl}_{2}-\mathrm{Amp}_{2}-\mathrm{Ep}-\mathrm{Ttn}_{2}$ made not possible the application of inverse multiequilibrium thermobarometry to constrain $P-T$ conditions of shearing. Inverse thermobarometry as based on the hornblende-plagioclase (Anderson and Smith, 1995; Holland and Blundy, 1994) and the Ti-in-hornblende (Otten, 1984) thermometry and the temperature corrected Al-in-hornblende barometry (Anderson, 1996; Anderson and Smith, 1995; Schmidt, 1992) as derived from compositions of both the magmatic and syn-tectonic assemblages are used here. The $P-T$ estimates are obtained following the computation scheme

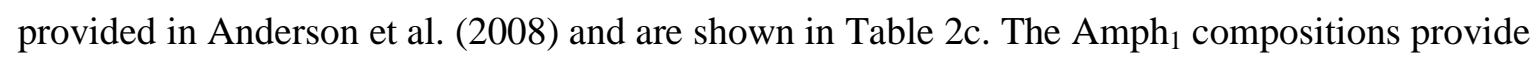


$P=0.15-0.2 \pm 0.06 \mathrm{GPa}(\mathrm{Al}-\mathrm{in}-\mathrm{Hbl}$ barometry $)$ and $T=629-638 \pm 25^{\circ} \mathrm{C}(\mathrm{Ti}-\mathrm{in}-\mathrm{Hbl}$

thermometry), in good agreement with $P$-T estimates calculated for $\mathrm{Pl}_{1}$-rims compositions $\left(\mathrm{X}_{\mathrm{An}}=\right.$ $35 \%$ ), which give $P=0.16-0.21 \pm 0.06 \mathrm{GPa} \mathrm{GPa}$ at $\mathrm{T}=590-632 \pm 30^{\circ} \mathrm{C}$. Thermobarometry using $\mathrm{Pl}_{1}$-core compositions $\left(\mathrm{X}_{\mathrm{An}}=66 \%\right)$ results in large uncertainty, suggesting no exchange equilibrium occurred between $\mathrm{Pl}_{1}$ core and $\mathrm{Amph}_{1}$ composition. The $\mathrm{Amph}_{2}$ composition shows $\mathrm{Al}_{\text {tot }}=0.70-0.81$ apfu that are near the lower limit of applicability of the horneblende-plagioclase thermobarometry (Anderson and Smith, 1995), indicating very low $P(<0.1 \mathrm{GPa})$ at $570-578 \pm$ $25{ }^{\circ} \mathrm{C}{ }^{\circ} \mathrm{C}$ (Ti-in-Hbl), compatible with Pl-Hbl thermometry $\left(531-556 \pm 30{ }^{\circ} \mathrm{C}{ }^{\circ} \mathrm{C}\right.$, for $\mathrm{X}_{\mathrm{An}}=25 \%$ in $\mathrm{Pl}_{2}$ ). These estimates are integrated with $\mathrm{Zr}$-in-titanite thermometry (Hayden et al. 2008). The mean $\mathrm{ZrO}_{2}$ content measured in $\mathrm{Ttn}_{1}$ is $0.02 \pm 0.01 \mathrm{wt} \%(1 \sigma, n=57)$. Assuming a $\mathrm{TiO}_{2}$ activity of 0.7 for rutile-free granitoids (Hayden et al. 2008) and a lithostatic pressure of $0.2 \mathrm{GPa}$, temperature estimates range $628-691{ }^{\circ} \mathrm{C}$ (Table $2 \mathrm{~d}$ ). The $\mathrm{ZrO}_{2}$ content of $\mathrm{Ttn}_{2}$ is systematically below the detection limit of the microprobe $(<0.01 \mathrm{wt} \%)$, attesting lower temperature conditions during the solid-state (syn-shearing) metamorphic overprint.

Collectively, the $P-T$ conditions in the transition from magma crystallization and activation of ductile shearing along the GDF can be placed in the temperature windows of 530$690{ }^{\circ} \mathrm{C}$ for pressure around $0.2 \mathrm{GPa}$. In particular, the thermobaric environment for shear zone nucleation and development are placed at $530-580{ }^{\circ} \mathrm{C}$ for pressure below of ca. $0.2 \mathrm{GPa}$. Assuming an average crustal density of $2700 \mathrm{~kg} / \mathrm{m}^{3}$, this scenario conforms to an apparent paleogeothermal gradient of about $70-90{ }^{\circ} \mathrm{C} / \mathrm{km}$.

\section{Titanite U-Pb geochronology}

An in situ laser ablation induction-coupled mass spectrometry (LA-ICPMS) U-(Th)-Pb dating approach was adopted in this study to constrain age of shearing on selected samples from the protomylonitic (T14-09 sample) and mylonitic (T14-06 sample) zones of the GDF. Analytical protocols and method adopted in this study are detailed in the Appendix. Analytical 
results are listed in Table 3. Plots and age calculations were made using the ISOPLOT4.1

software (Ludwig, 2003). Selected spots $(n=180)$ of $30-43 \mu \mathrm{m}$ in diameter show that titanites have variable concentrations of $U(11-830 \mathrm{ppm})$ with generally low concentrations of radiogenic ${ }^{206} \mathrm{~Pb}(0.02-3 \mathrm{ppm}$; mean: $0.5 \mathrm{ppm})$ and high common $\mathrm{Pb}$ (e.g. 63 to $>99 \%$ of ${ }^{206} \mathrm{~Pb}$ is common).

In the Tera-Wasserburg diagram, the measured, uncorrected, compositions of titanites cluster close to the Concordia for both samples, yielding nearly coincident lower intercept ages of $15.78 \pm 0.64 \mathrm{Ma}$ and $15.42 \pm 0.39 \mathrm{Ma}$, for the proto-mylonitic (T14-09) and mylonitic (T1406) sample, respectively (Fig. 6). Elevated MSWD of 2.0 (T14-09) and 3.2 (T14-06) indicate some scatter of the data, suggesting either disturbance of the isotope system or that the analysed domains do not represent a homogeneous age population. The upper intercepts correspond to a common lead compositions of ${ }^{207} \mathrm{~Pb} /{ }^{206} \mathrm{~Pb} 0.836 \pm 0.003$ (T14-09) and 0.840 \pm 0.003 (T14-06), which are very close or within uncertainty of the ${ }^{207} \mathrm{~Pb} /{ }^{206} \mathrm{~Pb}$ value predicted by the model of Stacey and Kramers (1975) at $15.5 \mathrm{Ma}$. Anchoring the ${ }^{207} \mathrm{~Pb} /{ }_{206} \mathrm{~Pb}$ value data sets to the Stacey and Kramer model (0.8367) results in a only small difference of the lower intercept ages, of 0.10 (T14-9) and 0.47 Ma (T14-6), respectively. Therefore, the data does not indicate any heterogeneity of the common $\mathrm{Pb}$ systematics during solid-sate shearing and recrystallisation.

Collectively, the common $\mathrm{Pb}$ corrected ${ }^{206} \mathrm{~Pb} /{ }^{238} \mathrm{U}\left({ }^{206} \mathrm{~Pb} * / 238 \mathrm{U}\right)$ ages range from $18.1 \pm 0.7$ to $11.2 \pm 0.7 \mathrm{Ma}$ (Table 3) It is worth nothing that the ${ }^{206} \mathrm{~Pb} * /{ }^{238} \mathrm{U}$ ages correlate with $\mathrm{Th} / \mathrm{U}$ ratios and zoning domains in Ttn, with the oldest ages from the oscillatory zoned high $\mathrm{Th} / \mathrm{U}$ domains and the youngest ages from the homogeneous overgrowth low Th/U domains, respectively (Fig. 7). Best fit Gaussian ${ }^{206} \mathrm{~Pb} * / 238 \mathrm{U}$ age plots for the two samples consistently shows a bimodal distribution with peaks at $17.1 \pm 0.2 \mathrm{Ma}(73 \%$ of the data population; $n=54)$ and $14.4 \pm 0.3 \mathrm{Ma}$ ( $27 \%$ of the data population) and $16.1 \pm 0.1 \mathrm{Ma}(63 \%$ of the data population; $n=124)$ and $14.5 \pm$ 0.1 Ma (37\% of the data population), for sample T14-09 and T14-06, respectively (Figs. 6a-b).

\section{Discussion}


The textural and petrographic features described in this study are compatible with a syn-

tectonic, metamorphic overprint that operated below the solidus temperature of the Salihli granodiorite during transformation of the granodiorite to orthogneiss. In particular, taking into account (i) the syn-tectonic recrystallization of feldspar grains, suggesting deformation under high-to medium-grade temperature conditions $\left(\sim 600-400{ }^{\circ} \mathrm{C}\right)($ Fig. 4$)$, and (ii) the results from hornblende-plagioclase inverse thermobarometry (see Table 2c-d), ductile shearing and mylonite formation in the investigated rocks took place under retrograde conditions and was completed below $600{ }^{\circ} \mathrm{C}$ in a continuum from magma crystallisation to solid-state shearing that occurred at shallow crustal conditions and thermal environments indicative of the upper-greenschist to lower-amphibolite facies metamorphic conditions ( $\left.\operatorname{climax} T=\sim 600-500{ }^{\circ} \mathrm{C}\right)$.

Mylonitization was dominantly assisted by retrograde, fluid-mediated reactions at the expenses of the pristine igneous assemblage, during replacement of the main magmatic assemblage $\mathrm{K}-\mathrm{Fsp}+\mathrm{Hb}+\mathrm{Mg} / \mathrm{Ilm}$ and the syn-tectonic growth of $\mathrm{Bt}_{2}-\mathrm{Ep}-\mathrm{Qz} \pm \mathrm{Pl}_{2}$. This was associated with alkalis, $\mathrm{Ca}, \mathrm{Fe}$ and $\mathrm{Mg}, \mathrm{H}^{+}$, and $\mathrm{SiO}_{2}$ mobility, mostly consequence of the alteration of the Amp-Fsp igneous assemblage (e.g., Aleinikoff et al., 2002; Wintsch et al., 2005), and lost of the almost entire REE budget in the transition from $\operatorname{Ttn}_{1} \operatorname{to~} \operatorname{Tt}_{2}$ during structurally-controlled fluid flow. The occurrence of REE-rich magmatic $\left(\mathrm{Ttn}_{1}\right)$ and REE-poor metamorphic $\left(\mathrm{Ttn}_{2}\right)$ titanite in the same samples allows possibility to constrain time of magma crystallisation and solid-state shearing through $\mathrm{U}-\mathrm{Th}-\mathrm{Pb}$ geochronology. Distinction between magma crystallisation and shearing is challenging because the Ttn growth occurred in a narrow time lapse and in a temperature window $\left(500-750^{\circ} \mathrm{C}\right)$ that is within the closure temperature interval of the U-Pb systematics (Cherniak, 1993; Spencer et al., 2013) and therefore almost within limits of the method. Nonetheless, the fact that there is no evidence of common $\mathrm{Pb}$ heterogeneity in the two generations of titanites, together with (i) the spread of ${ }^{206} \mathrm{~Pb}^{*} /{ }^{238} \mathrm{U}$ ages (Figs. 6 and 7), (ii) the textural and mineralogical evidence documenting fluid assisted recrystallisation and metasomatism (Catlos et al., 2010; this study), and (iii) the REE redistribution in Ttn that spatially correlates with the chemical zoning and the U-Pb-Th systematics in Ttn (see also Bonamici et al., 2015) (Figs. 5 and 7) collectively suggest that the Ttn from the 
Salihli granodiorite preserve predominantly open-system dates and radiogenic $\mathrm{Pb}$ diffusion during fluid-assisted syn-tectonic allochemical re-equilibration/recrystallization of Ttn. Previously reported U-Pb TIMS ages of $16.1 \pm 0.2 \mathrm{Ma}$ (monazite, Turgutlu granodiorite) and 15.0 \pm 0.3 Ma (allanite, Salihli granodiorite) (Glodny and Hetzel, 2007) are within uncertainty identical to our lower intercept U-Pb Ttn ages using spots of all analysed domains (Fig. 6). This suggests that the TIMS ages as our lower intercept ages dominantly record mixed ages, resulting from the analytical mixing of multiple (magmatic and metamorphic) age domains. We therefore propose that the bimodal distribution of the ${ }^{206} \mathrm{~Pb} * / 238 \mathrm{U}$ Ttn ages (Fig. 6) records the transition from magma crystallization and emplacement (at ca. 16-17 Ma) to the syn-tectonic, solid-state recrystallisation (at ca. 14.5 Ma) of the Salihli granodiorite. A time lapse of about 1-2 Ma is therefore suggested between the crustal emplacement of the Salihli granodiorite and the activation of the ductile top-to-the-NNE extensional tectonics along the GDF.

\section{Cooling history of the Salihli granodiorite: linking exhumation to extensional}

\section{shearing}

The rock microtextures attests for heterogeneous strain during progressive development of the shear zone fabrics along the GDF, from temperatures in the order of $400-600{ }^{\circ} \mathrm{C}$ down to low-grade conditions of $<250{ }^{\circ} \mathrm{C}$ and hence from ductile- to-brittle-dominated shearing (see also Catlos et al., 2011; Hetzel et al., 1995a; Işik et al., 2003). Based on the results as obtained from the U-(Th)-Pb geochronology applied to the different (igneous and metamorphic) titanite generations, and assuming (i) the final crystallization/emplacement temperature of the Salihli granodiorite at $\sim 630-700^{\circ} \mathrm{C}\left(\mathrm{Zr}-\mathrm{in}-\mathrm{Ttn}_{1}\right.$ thermometry) at $\sim 17 \mathrm{Ma}$ (sample T14-09), (ii) the thermal environment associated with the solid-state syn-metamorphic overprint during ductile shearing as occurred under amphibolite-grade conditions ( $T$ window $530-580{ }^{\circ} \mathrm{C}$; Amp-Pl thermobarometry) and completed at $\sim 14 \mathrm{Ma}$ (sample T14-06), and (iii) taking into account published radiometric and thermochronological age data (Buscher et al., 2013; Catlos et al., 
2008, 2010; Gessner et al., 2001; Glodny and Hetzel, 2007; Hetzel et al., 1995a; 2013; Lips et

al., 2001; Ring et al., 2003), it is possible to reconstruct the time-temperature $(T-t)$ evolution of the Salihli granodiorite at the footwall of the GDF (Fig. 8). In particular, the following key thermochronological constrains are assumed here: (i) cooling below $350 \pm 50{ }^{\circ} \mathrm{C}$ (McDougall and Harrison, 1999) is placed at 12 Ma based on Ar-Ar dating of biotite from the Salihli granodiorite (Hetzel et al., 1995a), and (ii) the final exhumation/cooling evolution below $260 \pm$ $20{ }^{\circ} \mathrm{C}$ as constrained by the ZFT, AFT and the ZHe and AHe thermochronology (Buscher et al., 2013; Gessner et al., 2001a; Ring et al., 2003).

The reconstructed $T$ - $t$ diagram shows four distinct phases of cooling since the early/middle Miocene boundary, marked by different cooling rates and characterized by two episodes of enhanced cooling that both operated at rates of $\sim 100^{\circ} \mathrm{C} / \mathrm{km}$, in the time lapse of 12 $14 \mathrm{Ma}$ and 2-3 Ma, respectively (Fig. 8). After $\sim 12$ Ma cooling rate dramatically decreased until $\sim 5 \mathrm{Ma}$, with a mean value of $13^{\circ} \mathrm{C} / \mathrm{Ma}$. This is followed by renewed cooling that culminated with the final episode starting at $\sim 3$ Ma. This final episode corresponds to the final exhumation event that drove the Salihli granodiorite and the GDF toward the surface (see also Buscher et al., 2013).

Two major implications are derived from the reconstructed $T$ - $t$ history.

(1) The thermal perturbation associated with crystallisation, emplacement and onset of ductile deformation of the Salihli granodiorite in the crustal section of the MMCC was a long-lasting event that operated at temporal scales in the order of $10^{6}$ years. Thermorheological modeling of the post-intrusive scenario in the crust predicts that the conditions for ductile deformation should last for a much shorter time interval, in the order of $10^{4}-10^{5}$ years (e.g., Caggianelli et al., 2013). A similar long-lasting thermal perturbation associated with granite emplacement in an extending crustal section has been documented in the Larderello geothermal field of Central Italy, where anomalous high gradient geothermal conditions were documented in the last $3 \mathrm{Ma}$, in concomitance with multiple granite intrusion ad depth (Bertini et al., 2006; Dini et al., 2004; Rossetti et al., 2008). This suggests that the Miocene Salihli and Turgutlu granodiorites likely were 
the upper crustal apophyses of a deeper magma chamber responsible for the maintenance of a long-lasting regional positive thermal anomaly.

(2) The $T$ - $t$ diagram points to a pulsed nature of the cooling/exhumation history of the Salihli granodiorite, which also reflects the space-time rheological evolution (from ductile to brittle shearing) of the GDF. In particular, the reconstructed $T-t$ evolution suggests that the transition from ductile to brittle behavior along the GDF did not occur as a continuous process, but was instead punctuated in time. Ductile, solid-state shearing is here placed in the 12-14 Ma time lapse, while an upper bound for the transition to brittle conditions along the GDF can be placed at $\sim 7 \pm 1 \mathrm{Ma}$, as derived from the ${ }^{40} \mathrm{Ar} /{ }^{39} \mathrm{Ar}$ dating of synkinematic white micas from the topmost horizons of the GDF (Lips et al., 2001) (Fig. 8). This is in line with the published low- $T$ thermochronological data, showing that variations in the exhumation rates of the Salihli granodiorite have occurred in the last 5-6 Ma, ranging between 0.6 and $2.2 \mathrm{~km} / \mathrm{Ma}$ (Buscher et al., 2013).

Similarly to many metamorphic core complexes (Whitney et al., 2013), the last rapid cooling/exhumation phase (at rates in the order of $100{ }^{\circ} \mathrm{C} / \mathrm{Ma}$ ), starting at $\sim 3 \mathrm{Ma}$, occurred when the footwall rocks of the GDF ascended to shallow crustal levels and normal faulting of the brittle upper crust, likely assisted by structurally-controlled fluid circulation (e.g. Morrison and Anderson, 1998), favored refrigeration of the exhuming footwall rocks.

Finally, it is worth noting that the composite exhumation model for the GDF and its delayed ductile (early-middle Miocene) to brittle (latest Miocene-Pliocene) activity as documented in this study is also compatible with the pulsed extension model proposed for the stratigraphic arrangement and structural evolution of the supradetachement Gediz Graben (Öner and Dilek, 2010; Purvis and Robertson, 2007)

\section{Comparison with the Aegean region and a model for the development of the GDF}

In the Aegean region, the Neogene post-orogenic tectonic setting is dominated by the activation of multiple ductile-to-brittle extensional detachment systems (Grasemann et al., 2012; Jolivet et al., 2010 and references therein) associated with the polyphase syn-tectonic, middle 
Miocene ( 17-10 Ma) emplacement of I- and S-type magmatic intrusions (e.g., Altherr et al.,

1982; Bolhar et al., 2010; Jolivet and Brun, 2010; Lee and Lister, 1992). Emplacement of the main Miocene Aegean granitoids occurred when the formation of metamorphic core complexes and ductile extensional deformation were already going on, as shown by the cases of Mykonos, Ikaria, Naxos, Paros and Serifos islands, where the intrusion of granitoids postdates the onset of migmatization and granitic bodies intruded older ductile extensional detachments (e.g. Brichau et al., 2007; Denèle et al., 2011; Duchêne et al., 2006; Laurent et al., 2015; Rabillard et al., 2015; Seward et al., 2009).

In the Menderes Massif, the onset of ductile extensional tectonics is constrained to the Early Miocene (21-22 Ma) by the activity of the Simav detachment fault and the syn-tectonic magmatism at the northern termination of the massif (Çemen et al., 2006; Işik et al., 2003; Fig. 1). In the same region, stratigraphic evidence from the "NE-trending basins" (Selendi, Gördes, Demirci and Uşak basins; Fig. 1) attests that the Menderes basement rocks were already exhumed and exposed to erosion since the early-middle Miocene times ( 14-21 Ma; Ercan et al., 1996; Ersoy et al., 2008, 2012, 2014; Karaoğlu et al., 2010; Purvis et al., 2005; Seyitoğlu et al., 1992, 1997). Low-temperature thermochronological studies support this inference, with the majority of the AFT ages ranging between $\sim 30$ and $\sim 15$ Ma (Gessner et al., 2001a, 2013; Ring et al., 2003; Thomson and Ring, 2006). These data suggest that most of the Menderes Massif was already exhumed above the closure isotherm of the AFT system well before activation of the solid-state shearing of the Salihli granodiorite along the GDF, constrained at $~ 14$ Ma in this study. As a matter of fact, no evidence of Neogene ductile extensional deformation predating the intrusion of the Turgutlu and Salihli plutons has been reported in the literature. Furthermore, younger ZFT and AFT ages (ranging 2-10 Ma; Buscher et al., 2013) are located only at the footwall of the main extensional detachment systems bounding the central part of the Menderes Massif, the Gediz Detachment to the N and the Büyük Menderes Detachment to the $\mathrm{S}$, respectively (Fig. 1). This evidence suggests that even if extensional tectonics was already active in other areas of the Menderes Massif, at the local scale, the emplacement of the Salihli and 
Turgutlu granodiorites created the rheological conditions for the nucleation and localization of ductile extensional shearing on the GDF.

To sum-up, different crustal domains were exhumed along the Aegean-Menderes transect, with deeper crustal levels and higher degree of partial melting exposed in the Aegean with respect to the Menderes region. The formation of metamorphic core complexes is favored when high geothermal conditions in a thick crustal section promote efficient decoupling between the upper and lower crustal deformation during regional extension (e.g., Bassi, 1995; Brun et al, 1994; Buck, 1991; Gueydan et al., 2014; Whitney et al., 2013). Crustal melting facilitates decoupling by reducing the effective viscosity and density of the lower crust, determining positive feedbacks between extension and magmatism in core complexes development (Whitney et al., 2013). It is therefore evident that post-orogenic extensional tectonics operated on different geothermal/rheological crustal sections in the Aegean and Menderes realms. In the Aegean, large-scale extension triggered the continuous ascent of the hot, partially molten ductile crust promoting partial melting at different crustal levels, with generation of multiple and distributed extensional detachments. On the other hand, in the Menderes crustal decoupling was not sufficient enough to localize crustal thinning and ductile flow of the lower crust at regional scale. At local scale, instead, pluton emplacement at shallow crustal conditions caused the rheological weakening of the upper crust, generating the conditions for the localization of ductile extensional shearing and onset of extensional detachment tectonics in the Menderes. This is confirmed by the field evidence attesting the GDF wrapping around the Salihli granodiorite (Fig. 2), which supports the idea that the shape, distribution and activity of extensional detachment was strongly controlled by magma emplacement in the upper crust.

Based on the above, we propose a synthetic tectonic evolutionary model for the activation and development of the GDF in the transition from ductile to brittle deformation conditions (Fig. 9). The model starts in the Early Miocene, when regional crustal thinning promoted the rise of the geothermal gradient and melting of the lower crust (e.g., Whitney et al., 2004; 2013; Vanderhaeghe and Teyssier, 2001). Positive feedbacks between crustal, thinning and melting allowed focused lower crustal flow below the site of active extension, resulting in further 
decompressional melting and segregation of the Sahlili granodiorite at ca. 17 Ma. Continuous

crustal thinning allowed magma emplacement at shallow crustal levels and the transient, local, rise of the regional brittle-ductile transition zone. This process was associated with rheological weakening of the crustal section, allowing ductile shear strain localisation along the exhumed brittle-ductile transition zone and development of GDF at ca. 14 Ma. Solid shearing of the Sahlili granodiorite at the footwall of the GDF was accompanied by formation and subsidence of the Gediz Graben at the hangingwall of the GDF . Continued shearing along the GDF favored focused exhumation at the footwall of the GDF, dominantly assisted by high-angle brittle extensional faulting (Fig. 9).

\section{Concluding remarks}

The integrated textural, thermobaric and $\mathrm{U}-(\mathrm{Th})-\mathrm{Pb}$ titanite geochronological data presented in this study provide evidence that crustal magma emplacement predated onset of the Miocene Gediz-Alaşehir extensional detachment in the Menderes Massif. This evidence suggests that activation of ductile extension was a consequence, rather than the cause, of magma emplacement in the extending crust during the Neogene crustal tinning in the region. This reconstruction also impacts on the amount of exhumation and, more in general, on the amount of extension accommodated by the detachment faults in the Menderes that could be much less than generally thought.

Finally, results of this study reinforce the importance of the rheological perturbation caused by magma intrusion in the crust and, in particular, the role of transient ductile-to-brittle transition and strain softening processes associated with pluton emplacement (e.g. Brun et al., 1994; Caggianelli et al., 2013; Lister and Baldwin, 1993; Parsons and Thompson, 1993; Rabillard et al., 2015) in controlling localization and nucleation of ductile extensional detachment tectonics in extensional provinces. 


\section{Appendix: Analytical methods and protocols}

\section{U-Th-Pb geochronology}

Titanites were analysed in in situ in thin section by laser ablation inductively coupled plasma mass spectrometry (LA ICP-MS) at the Goethe University of Frankfurt (GUF), using a slightly modified method, as previously described in Gerdes and Zeh (2006, 2009) and Millonig et al. (2012). A ThermoScientific Element 2 sector field ICP-MS was coupled to a Resolution $193 \mathrm{~nm}$ ArF Excimer laser (CompexPro 102, Coherent) equipped with two-volume ablation cell (S-155; Laurin Technic, Australia). Data were acquired in time-resolved pulse counting mode, with a laser energy of below $2 \mathrm{~J} \mathrm{~cm}^{-2}$, a $5 \mathrm{~Hz}$ repetition rate and spot size of $43 \mu \mathrm{m}$ for titanites and 30 $\mu \mathrm{m}$ for GJ-1 reference zircon. Raw data was corrected offline for background signal, common $\mathrm{Pb}$ and laser induced, time-dependent element fractionation using an in-house Excel spreadsheet program (Gerdes and Zeh, 2006, 2009). Common $\mathrm{Pb}$ was estimated iterative from the non radiogenic ${ }^{207} \mathrm{~Pb}$ calculated from the ${ }^{206} \mathrm{~Pb} /{ }^{238} \mathrm{U}$ age and the ${ }^{206} \mathrm{~Pb}$ signal assuming a concordant analysis (see Millonig et al. 2012) and a model Pb composition (Stacey and Kramers, 1975). Subsequently elemental fractionation and mass discrimination were monitored and corrected using GJ-1 zircon as primary reference, while Bearlake titanite BLR and GUF Namaqualand titanite $\mathrm{T} 1$ were measured as unknowns to assess precision and accuracy. Repeated analyses ( $\mathrm{n}=$ 8 and 13) of these secondary reference titanites yield ${ }^{206} \mathrm{~Pb} /{ }^{238} \mathrm{U}$ and ${ }^{207} \mathrm{~Pb} /{ }^{206} \mathrm{~Pb}$ ratios that are precise to about $1 \%(\mathrm{SD} \sim 0.8 \%$ ) and $2 \%(\mathrm{SD} \sim 1.8 \%$ ), respectively and overlap within $1 \%$ with ${ }^{206} \mathrm{~Pb} /{ }^{238} \mathrm{U}$ ID-TIMS ages (BLR, 1047.1 $\pm 0.4 \mathrm{Ma}$ (Aleinikoff et al., 2007); T1, 998 $\pm 2 \mathrm{Ma}$, GUF, unpublished data). Thus there was no need to apply an offset factor to correct for the different sample matrix relative to zircon as primary reference. This was probably accomplish by using the low fluency during ablation and the smaller spot size for GJ-1 zircon.

\section{Electron Microprobe Analysis (EMPA)}


Electron microprobe: Mineral compositions were analyzed at Universität Stuttgart using a

Cameca SX100 eletron microprobe. Operating conditions for rock forming minerals were $15 \mathrm{kV}$, 10 to $15 \mathrm{nA}$. For the analyses of mica and feldspar, we applied a beam diameter of $5 \mu \mathrm{m}$. The used standards were natural wollastonite $(\mathrm{Ca}, \mathrm{Si})$, natural orthoclase $(\mathrm{K})$, natural albite $(\mathrm{Na})$, natural rhodonite $(\mathrm{Mn})$, synthetic $\mathrm{Cr}_{2} \mathrm{O}_{3}(\mathrm{Cr})$, synthethic $\mathrm{TiO}_{2}(\mathrm{Ti})$, natural hematite $(\mathrm{Fe})$, synthetic $\mathrm{MgO}(\mathrm{Mg})$, and synthetic $\mathrm{Al}_{2} \mathrm{O}_{3}(\mathrm{Al})$. For the analyses of titanite, conditions of $15 \mathrm{kV}$ and $100 \mathrm{nA}$ were adopted. Additional standards were synthetic REE orthophosphates (Donovan, et al. 2003; Jarosewich and Boatner, 1991). The following detection limits for selected REE

elements were calculated: 0.10 wt.\% La, 0.06 wt.\% Ce, 0.17 wt.\% Gd, 0.19 wt.\% Dy, 0.15 wt.\% Pr, 0.10 wt.\% Nd, 0.19 wt.\% Sm, 0.07 wt.\% Er, 0.07 wt.\% Yb, and 0.02 wt.\% Y. In addition, F (standard $\mathrm{BaF}_{2}$, detection limit 0.03 wt.\%), $\mathrm{P}$ (graftonite, 0.01 wt.\%), $\mathrm{Nb}$ (pure $\mathrm{Nb}, 0.02$ wt.\%), and $\mathrm{Zr}$ (zircon, 0.01 wt.\%) were measured.

\section{Acknowledgements}

This paper benefitted of constructive reviews and criticism from an anonymous reviewer and B. Cenki-Tok. Field assistance by Üha Özden, Oğuz H. Gögǚş, Alper Yangöz, Semih Can Ülgen and Nazik Öğretmen is kindly acknowledged. 


\section{References}

Aleinikoff, J.N., Wintsch, R.P., Fanning, C.M., Dorais, J.M., 2002. U-Pb geochronology of zircon and polygenetic titanite from the Glastonbury Complex, Connecticut, USA: an integrated SEM, EMPA, TIMS, and SHRIMP study. Chemical Geology 188, 125- 147.

Aleinikoff, J.N., Wintsch, R.P., Tollo, R.P., Unruh, D.M., Fanning, C.M., Schmitz, M.D., 2007. Ages and origins of rocks of the Killingworth Dome, south-central Connecticut: implications for the tectonic evolution of southern New England. American Journal of Science 307, 63118.

Altherr, R., Kreuzer, H., Wendt, I., Lenz, H., Wagner, G.A., Keller, J., Harre, W., Hohndorf, A., 1982. A Late Oligocene/Early Miocene high temperature belt in the anti-cycladic crystalline complex (SE Pelagonian, Greece). Geologisches Jahrbuch 23, 97-164.

Altunkaynak, Ş., Dilek, Y., Genç, C.Ş., Sunal, G., Gertisser, R., Furnes, H., Foland, K.A., Yang, J., 2012. Spatial, temporal and geochemical evolution of Oligo-Miocene granitoid magmatism in western Anatolia, Turkey. Gondwana Research 21, 961-986.

Anderson, J. L. 1996. Status of thermobarometry in granitic batholiths. Transactions of the Royal Society of Edinburgh 87, 125-138.

Anderson, J.L., Smith, D.R., 1995. The effect of temperature and oxygen fugacity on Al-inhornblende barometry. American Mineralogist 80, 549-59.

Anderson, J. L., Barth, A. P., Wooden, J. L., Mazdab, F., 2008. Thermometers and thermobarometers in granitic systems. Reviews in Mineralogy and Geochemistry 69(1), 121-142.

Aoya, M., Wallis, S.R., Terada, K., Lee, J., Kawakami, T., Wang, Y., Heizler, M., 2005. Northsouth extension in the Tibetan crust triggered by granite emplacement. Geology 33, 853-856. Asti R., Malusà, M.G., Faccenna, C., 2016. Unraveling supradetachment basin evolution by detrital apatite fission track analysis: the Gediz Graben (Menderes Massif, Western Turkey). Rendiconti Online della Società Geologica Italiana 40, sup. 1, DOI: 10,3301/ROL.2016.79. 
Bassi, G., 1995. Relative importance of strain rate and rheology for the mode of continental extension. Geophysical Journal International, 122, 195-210.

Berthé, D., Choukroune, P., Jegouzo, P., 1979. Orthogneiss, mylonite and non coaxial deformation of granites: the example of the South Armorican Shear Zone. Journal of Structural Geology 1, 31-42.

Bertini, G., Casini, M., Gianelli, G., Pandeli, E., 2006. Geological structure of a long-living geothermal system, Larderello, Italy. Terra Nova 18 (3), 163-169.

Bolhar, R., Ring, U. and Allen, C.M., 2010. An integrated zircon geochronological and geochemical investigation into the Miocene plutonic evolution of the Cyclades, Aegean Sea, Greece: Part 1: Geochronology. Contribution to Mineralogy and Petrology 160, 719-742, DOI 10.1007/s00410-010-0504-4.

Bonamici, C.E., Fanning, C.M., Kozdona, R., Fournellea, J.H., Valleya, J.W., 2015. Combined oxygen-isotope and $\mathrm{U}-\mathrm{Pb}$ zoning studies of titanite: New criteria for age preservation. Chemical Geology 398, 70-84.

Bozkurt, E., Park, G.R., 1994. Southern Menderes massif: an incipient metamorphic core complex in western Anatolia, Turkey. Journal of the Geological Society of London 151, 213 216.

Bozkurt, E., Sözbilir, H., 2004. Tectonic evolution of the Gediz Graben: field evidence for an episodic, two-stage extension in western Turkey. Geological Magazine 141, 63-79.

Bozkurt, E., Satır, M., Buğdaycıoğlua, Ç., 2011. Surprisingly young Rb/Sr ages from the Simav extensional detachment fault zone, northern Menderes Massif, Turkey. Journal of Geodynamics 52, 406-431.

Brichau, S., Ring, U., Carter, A., Monie, P., Bolhar, R., Stockli, D., Brunel, M., 2007. Extensional faulting on Tinos Island, Aegean Sea, Greece: how many detachments? Tectonics 26, TC4009. doi:10.1029/2006TC001969

Brun, J.P., Sokoutis, D., Van Den Driessche, J., 1994. Analogue modelling of detachment fault systems and core complexes. Geology 22, 319-322. 
Buck, W.R., 1991. Modes of continental lithosphere extension. Journal of Geophysical Research 96(B12): 20,161-20,178.

Buscher, J.T., Hampel, A., Hetzel, R., Dunkl, I., Glotzbach, C., Struffert, A., Akal, C., Ratz, M., 2013. Quantifying rates of detachment faulting and erosion in the central Menderes massif (western Turkey) by thermochronology and cosmogenic 10Be. Journal of the Geological Society of London 170, 669-683.

Caggianelli, A., Ranalli, G., Lavecchia, A., Liotta, D., Dini, A., 2013. Post-emplacement thermorheological history of a granite intrusion and surrounding rocks: the Monte Capanne pluton, Elba Island, Italy. Geological Society, London, Special Publications, 394, http://dx.doi.org/10.1144/SP394.1.

Candan, O., Dora, O.Ö., Oberhänsli, R., Çetinkaplan, M., Partzsch, J.H., Warkus, F.C., Dürr, S., 2001. Pan-African high-pressure metamorphism in the Precambrian basement of the Menderes Massif, western Anatolia, Turkey. International Journal of Earth Sciences (Geologische Rundschau) 89, 793-811.

Catlos, E.J., Baker, C., Sorensen, S.S., Cemen, I., Hancer, M., 2008. Monazite geochronology, magmatism and extensional dynamics within the Menderes massif, Western Turkey. IOP Conference Series: Earth and Environmental Science, 2, paper 012015, 2 pp, doi:10.1088/1755-1307/2/1/012015.

Catlos, E.J., Baker, C., Sorensen, S.S., Çemen, I., Hancer, M., 2010. Geochemistry, geochronology, and cathodoluminescence imagery of the Salihli and Turgutlu granites (central Menderes Massif, western Turkey): implications for Aegean tectonics. Tectonophysics 48, 110-130.

Catlos, E.J., Baker, C.B., Sorensen, S.S., Jacob, L., Çemen, I., 2011. Linking microcracks and mineral zoning of detachment-exhumed granites to their tectonomagmatic history: Evidence from the Salihli and Turgutlu plutons in western Turkey (Menderes Massif). Journal of Structural Geology 33 (5), 951-969.

Çemen, I., Catlos, E.J., Gögüs, O., Özerdem, C., 2006. Postcollisional extensional tectonics and exhumation of the Menderes massif in the Western Anatolia extended terrane, Turkey. In: 
Dilek, Y., Pavlides, S. (Eds.), Postcollisional Tectonics and Magmatism in the Mediterranean Region and Asia: Geological Society of America Special Paper 409, 353-379.

Cherniak, D.J., 1993. Lead diffusion in titanite and preliminary results on the effects of radiation damage on Pb transport. Chemical Geology 110, 177-194.

Çiftçi, N.B., Bozkurt, E., 2009. Evolution of the Miocene sedimentary fill of the Gediz Graben, SW Turkey. Sedimentary Geology 216, 49-79.

Coney, P.J., 1974. Structural analysis of the Snake Range "décollement," east-central Nevada. Geological Society of America Bulletin 88, 1237-1250.

Coney, P.J., 1980. Cordilleran metamorphic core complexes: An overview, in Crittenden, M.D., Coney, P.J., and Davis , G.H. (Eds.), Cordilleran Metamorphic Core Complexes: Geological Society of America Memoir 153, 7-34.

Corti, G., Bonini, M., Conticelli, S., Innocenti, S., Manetti, P., Sokoutis, D., 2003. Analogue modelling of continental extension: a review focused on the relations between the patterns of deformation and the presence of magma. Earth-Science Reviews, 63, 169-247.

Crittenden, M.D., Jr., Coney, P.J., Davis, G.H. (Eds.), 1980. Cordilleran Metamorphic Core Complexes. Geological Society of America Memoir 153, 490 p.

Davis, G.H., Constenius, K.N., Dickinson, W. R., Rodríguez, E.P., Cox, L.J., 2004. Fault and fault-rock characteristics associated with Cenozoic extension and core-complex evolution in the Catalina-Rincon region, southeastern Arizona. Geological Society of America Bulletin $116,128-141$.

Denèle, Y., Lecomte, E., Jolivet, L., Lacombe, O., Labrousse, L., Huet, B., Le Pourhiet, L., 2011. Granite intrusion in a metamorphic core complex: The example of the Mykonos laccolith (Cyclades, Greece), Tectonophysics, 501, 52-70, doi:10.1016/j.tecto.2011.01.013.

Dilek, Y., Altunkaynak, S., Öner, Z., 2009. Syn-extensional granitoids in the Menderes core complex and the late Cenozoic extensional tectonics of the Aegean province. In: Ring, U., Wernicke, B. (Eds.), Extending a Continent: Architecture, Rheology and Heat Budget. Geological Society of London Special Publications 321, 197-223. 
Donavan, J.J., Hanchar, J.M., Picolli, P.M., Schrier, M.D., Boatner, L.A., Jarosewich, E., 2003.

A re-examination of the rare-earthelement orthophosphate standards in use for electron microprobe analysis. The Canadian Mineralogist 4,1221-232.

Drury, M.R., Urai, J.L., 1990. Deformation related recrystallization processes. Tectonophysics 172: $235-253$.

Duchêne, S., Aïssa, R., Vanderhaeghe, O., 2006. Pressure-temperature-time evolution of metamorphic rocks from Naxos (Cyclades, Greece): constraints from thermobarometry and Rb/Sr dating. Geodinamica Acta 19, 299-319. doi:10.3166/ga.19.301-321

Ercan, E., Satır, M., Sevin, D., Türkecan, A., 1996. Batı Anadolu'daki Tersiyer ve Kuvaterner yaşlı volkanik kayaçlarda yeni yapılan radyometrik yaş ölçümlerinin yorumu [Some new radiometric ages from Tertiary and Quaternary volcanic rocks from West Anatolia]. Mineral Research and Exploration Institute Bulletin (Turkey) 119, 103-112.

Erkül, F., 2010. Tectonic significance of synextensional ductile shear zones within the Early Miocene Alacamdag granites, northwestern Turkey. Geological Magazine 147, 611-637. Erkül, S.T., Erkül, F., 2012. Magma interaction processes in syn-extensional granitoids: the Tertiary Menderes metamorphic core complex, western Turkey. Lithos 142-143, 16-33. Erkül, F., Erkül, S.T., Ersoy, Y., Uysal, I., Krötzli, U., 2013. Petrology, mineral chemistry and $\mathrm{Sr}-\mathrm{Nd}-\mathrm{Pb}$ isotopic compositions of granitoids in the central Menderes metamorphic core complex: Constraints on the evolution of Aegean lithosphere slab. Lithos 180-181, 74-91.

Ersoy, Y., Helvac1, C., Sözbilir, H., Erkül, F., Bozkurt, E., 2008. A geochemical approach to Neogene-Quaternary volcanic activity of western Anatolia: an example of episodic bimodal volcanism within the Selendi Basin, Turkey. Chemical Geology 255, 265-282.

Ersoy, E.Y., Helvac1, C., Palmer, M.R., 2011. Stratigraphic, structural and geochemical features of the NE-SW-trending Neogene volcano-sedimentary basins in western Anatolia: implications for associations of supradetachment and transtensional strike-slip basin formation in extensional tectonic setting. Journal of Asian Earth Sciences 41, 159-183. 
Ersoy, E.Y., Helvac1, C., Palmer, M.R., 2012. Petrogenesis of the Neogene volcanic units in the NE-SW-trending basins in western Anatolia, Turkey. Contributions to Mineralogy and Petrology 163, 379-401.

Ersoy, E.Y., Çemen, İ., Helvacı, C., Billor, Z., 2014. Tectono-stratigraphy of the Neogene basins inWestern Turkey: Implications for tectonic evolution of the Aegean Extended Region. Tectonophysics 635, 33-58.

Famin, V., Philippot, P., Jolivet, L., Agard, P., 2004. Evolution of hydrothermal regime along a crustal shear zone, Tinos Island, Greece. Tectonics 23, TC5004, doi:10.1029/2003TC001509.

Gébelin, A., Mulch, A., Teyssier, C., Heizler, M., Vennemann, T., Seaton, N.C.A., 2011. OligoMiocene extensional tectonics and fluid flow across the northern Snake Range detachment system, Nevada. Tectonics 30, TC5010, doi:10.1029/2010TC002797.

Gapais, D., 1989. Shear structures within deformed granites: mechanical and thermal indicators. Geology 17 (12), 1144-1147.

Gerdes, A., Zeh, A., 2006. Combined U-Pb and Hf isotope LA-(MC-) ICP-MS analyses of detrital zircons: comparison with SHRIMP and new constraints for the provenance and age of an Armorican metasediment in Central Germany. Earth and Planetary Science Letters 249, 47-62

Gerdes, A., Zeh, A., 2009. Zircon formation versus zircon alteration-new insights from combined $\mathrm{U}-\mathrm{Pb}$ and $\mathrm{Lu}-\mathrm{Hf}$ in-situ La-ICP-MS analyses of Archean zircons from the Limpopo Belt. Chemical Geology 261, 228-241. doi:10.1016/j. chemgeo.2008.03.005.

Gessner, K., Ring, U., Johnson, C., Hetzel, R., Passchier, C.W., Gungor, T., 2001a. An active bivergent rolling-hinge detachment system: Central Menderes metamorphic core complex in western Turkey. Geology 29, 611-614.

Gessner, K., Piazolo, S., Gungor, T., Ring, U., Kroener, A., Passchier, C.W., 2001b. Tectonic significance of deformation patterns in granitoid rocks of the Menderes nappes, Anatolide Belt, Southwest Turkey. International Journal of Earth Sciences 89, 766-780. 
Gessner, K., Ring, U., Passchier, C.W., Gungor, T., 2001c. How to resist subduction: evidence

for large-scale out-of-sequence thrusting during Eocene collision in western Turkey. Journal of the Geological Society 158, 769-784.

Gessner, K., Gallardo, L.A., Markwitz, V., Ring, U., Thomson, S.N., 2013. What caused the denudation of the Menderes Massif: Review of crustal evolution, lithosphere structure, and dynamic topography in southwest Turkey. Gondwana Research 24 (1), 243-274.

Glodny, J., Hetzel, R., 2007. Precise U-Pb ages of syn-extensional Miocene intrusions in the central Menderes Massif, western Turkey. Geological Magazine 144, 235-246.

Grasemann, B., and C. Tschegg, 2012. Localization of deformation triggered by chemomechanical feedback processes, Geological Society of America Bulletin 124(5-6), 737-745, doi:10.1130/B30504.1.

Gueydan, F., Precigout, J., Montési, L.G.J., 2014. Strain weakening enables continental plate tectonics. Tectonophysics 631, 189-196. http://dx.doi.org/10.1016/ j.tecto.2014.02.005.

Hayden, L.A., Watson, B.E, Wark, D.A, 2008. A thermobarometer for sphene (titanite). Contribution to Mineralogy and Petrology 155, 529-540

Hetzel, R., Ring, U., Akal, C., Troesch, M., 1995a. Miocene NNE-directed extensional unroofing in the Menderes Massif, southwestern Turkey. Journal of the Geological Society of London $152,639-654$.

Hetzel, R., Passchier, C.W., Ring, U., Dora, O.Ö, 1995b. Bivergent extension in orogenic belts; the Menderes Massif (southwestern Turkey). Geology 23, 455-458.

Hetzel, R., Reischmann, T., 1996. Intrusion age of Pan-African augen gneisses in the southern Menderes massif and the age of cooling after Alpine ductile extensional deformation. Geological Magazine 133, 565-572.

Hetzel, R., Romer, R.L., Candan, O., Passchier, C.W., 1998. Geology of the Bozdağ area, central Menderes massif, SW-Turkey: Pan African basement and Alpine deformation. Geologische Rundschau 87, 394-406.

Hirth, G., Tullis, J., 1992. Dislocation creep regimes in quartz aggregates. Journal of Structural Geology 14 (2), 145-159. 
Holland, T., Blundy, J., 1994. Non-ideal interactions in calcic amphiboles and their bearing on amphibole-plagioclase thermometry. Contributions to Mineralogy and Petrology 116, 43347.

Işik, V., Seyitoğlu, G., Çemen, I., 2003. Ductile-brittle transition along the Alaşehir detachment fault and its structural relationship with the Simav detachment fault, Menderes massif, western Turkey. Tectonophysics 374, 1-18.

Jarosewich, E., Boatner, L.A., 1991. Rare-earth element reference samples for electron microprobe analysis. Geostandards Newsletter 15, 397-399.

Leake, B.E., Alan, R.W., William, D.B., Ernst, A.J.B., Giovanni, F., Jeol, D.J., Frank, C.H., Hanan, J.K., Vladimir, G.K., John, C.S., Nicholas, C.N.S., Eric, J.W.W., 2004. Nomenclature of amphiboles: Additions and revisions to the International MineralogicalAssociations amphibole nomenclature. The American Mineralogist 89, 883887.

Jolivet, L., Daniel, J.M., Truffert, C., Goffe, B., 1994. Exhumation of deep crustal metamorphic rocks and crustal extension in arc and back-arc regions. Lithos 33, 3 - 30.

Jolivet, L., Patriat, M., 1999. Ductile extension and the formation of the Aegean sea. In: Durand, B., Jolivet, L., Mascle, A., Seranne, M. (Eds.), The Mediterranean Basins, Tertiary Extension within the Alpine Orogen, 427 - 456.

Jolivet, L., Lecomte, E., Huet, B., Denèle, Y., Lacombe, O., Labrousse, L., Le Pourhiet, L., Mehl, C., 2010. The North Cycladic detachment system. Earth and Planetary Science Letters 289, 87-104.

Jolivet, L., Brun, J.P., 2010. Cenozoic geodynamic evolution of the Aegean. International Journal of Earth Sciences 99, 109-138.

Karaoğlu, Ö., Helvacı, C., Ersoy, E.Y., 2010 - Petrogenesis and 40Ar/39Ar geochronology of the volcanic rocks of the Uşak-Güre basin, western Türkiye. Lithos 119, 193-210.

Laurent V., Beaudoin A., Jolivet L., Arbaret L., Augier R., Rabillard A., Menant A., 2015. Interrelations between extensional shear zones and synkinematic intrusions: The example of Ikaria Island (NE Cyclades, Greece). Tectonophysics 651-652, 152-171 
Lee, J., Lister, G., 1992. Late Miocene ductile extension and detachment faulting, Mykonos,

Greece. Geology 20, 121-124.

Leloup, P.H., Lacassin, R., Tapponnier, P., Schärer, U., Zhong, D., Liu, X., Zhang, L., Ji, S., Trinh, P.T., 1995. The Ailao Shan-Red River shear zone (Yunnan, China), Tertiary transform boundary of Indochina. Tectonophysics 251, 2-84.

Lips, A.L.W., Cassard, D., Sözbilir, H., Yilmaz, H., Wijbrans, J.R., 2001. Multistage exhumation of the Menderes Massif, western Anatolia (Turkey). International Journal of Earth Sciences (Geologische Rundschau) 89, 781-792.

Lister, G.S., Baldwin, S.L., 1993. Plutonism and the origin of metamorphic core complexes. Geology 21, 607-610.

Lister, G.S., Davis, G.A., 1989. The origin of metamorphic core complexes and detachment faults formed during Tertiary continental extension in the northern Colorado River region, USA. Journal of Structural Geology 11, 65-94, doi:10.1016/0191-8141(89)90036-9.

Ludwig, K.R., 2003. Isoplot/EX version 3.0, A geochronological toolkit for Microsoft Excel. Berkeley Geochronology Center Special Publication.

McDonough, W.F., Sun, S.S., Ringwood, A.E., Jagoutz, E., Hofmann, A.W., 1991. K, Rb and Cs in the Earth and Moon and the evolution of the earth's mantle. Geochimica et Cosmochimica Acta, Ross Taylor Symposium Volume.

McDougall, I., Harrison, T.M., 1999. Geochronology and Thermochronology by the 40Ar/39Ar method. Oxford University Press, New York, 212 pp.

Metcalf, R.V., Smith, E.I., 1995. Introduction to special section: Magmatism and extension. Journal of Geophysical Research 100 (10), 249-253.

Millonig, L.J., Gerdes, A., Groat, L.A., 2012. U-Th-Pb geochronology of metacarbonatites and meta-alkaline rocks in the sourthern Canadian Cordillera: a geodynamic perspective. Lithos $152,202-217$.

Morrison, J., Anderson, J.L., 1998. Footwall refrigeration along a detachment fault: Implications for the thermal evolution of core complexes. Science 279, 63-66. 
Oberhänsli, R., Candan, O., Wilke, F., 2010. Geochronological evidence of Pan-African eclogites from the central Menderes Massif, Turkey. Turkish Journal of Earth Sciences 19, 431-447.

Öner, Z., Dilek, Y., Kadığlu, Y.K., 2010. Geology and geochemistry of the synextensional Salihli granitoid in the Menderes core complex, western Anatolia, Turkey. International Geology Review 52, 336-368.

Öner, Z., Dilek, Y., 2011. Supradetachment basin evolution during continental extension: the Aegean province of western Anatolia, Turkey. Geological Society of America Bulletin 123, 2115-2141.

Otten, M.T., 1984. The origin of brown hornblende in the Artfjallet gabbro and dolerites. Contributions to Mineralogy and Petrology 86, 189-99.

Menegon, L., 2006. Ductile deformation of granitic rocks: selected examples from the Western Alps. Unpublished PhD Thesis, Universita` degli Studi di Padova, Italy.

Parsons, T., Thompson, G.A., 1993. Does magmatism influence low-angle normal faults? Geology 21, 247-250

Passchier, C.W., Trouw, R.A.J., 1996. Microtectonics. Berlin, Springer-Verlag, 289 pp.

Passchier, C.W., Trouw, R.A.J., 2005. Microtectonics. Berlin, Springer Verlag, 366pp.

Purvis, M., Robertson, A.H.F., 2005. Sedimentation of the Neogene-Recent Alaşehir (Gediz) continental graben system used to test alternative tectonic models for western (Aegean) Turkey. Sedimentary Geology 173, 373-408.

Purvis, M., Robertson, A., Pringle, M., 2005. 40Ar-39Ar dating of biotite and sanidine in tuffaceous sediments and related intrusive rocks: implications for the early Miocene evolution of the Gördes and Selendi basins, W Turkey. Geodinamica Acta 18, 239-253.

Rabillard, A., Arbaret, L., Jolivet, L., Le Breton, N., Gumiaux, C., Augier, R., Grasemann, B., 2015. Interactions between plutonism and detachments during metamorphic core complex formation, Serifos Island (Cyclades, Greece). Tectonics 34, 1080-1106. doi:

10.1002/2014TC003650. 
Régnier, J.L., Ring, U., Passchier, C.W., Gessner, K., Gungor, T., 2003. Contrasting

metamorphic evolution of metasedimentary rocks from the Cine and Selimiye nappes in the Anatolide belt, western Turkey. Journal of Metamorphic Geology 21, 699-721.

Régnier, J.L., Metzger, J.E., Passchier, C.W., 2007. Metamorphism of Precambrian-Palaeozoic schists of the Menderes core series and contact relationships with Proterozoic orthogneisses of the western Çine Massif, Anatolide belt, western Turkey. Geological Magazine 144, 67104.

Rey, P., Vanderhaeghe, O., Teyssier, C., 2001. Gravitational collapse of the continental crust: definition, regimes and modes. Tectonophysics 342, 435-449.

Rimmelé, G., Oberhänsli, R., Goffé, B., Jolivet, L., Candan, O., Cetinkaplan, M., 2003. Deformation history of the high-pressure Lycian Nappes and implications for tectonic evolution of SW Turkey. Tectonics 22, 1007.

Ring, U., Gessner, K., Gungor, T., Passchier, C.W., 1999. The Menderes Massif of western Turkey and the Cycladic Massif in the Aegean - do they really correlate? Journal of the Geological Society of London 156, 3-6.

Ring, U., Johnson, C., Hetzel, R., Gessner, K., 2003. Tectonic denudation of a Late CretaceousTertiary collisional belt: regionally symmetric cooling patterns and their relation to extensional faults in the Anatolide belt of western Turkey. Geological Magazine 140, 421441.

Ring, U., Collins, A.S., 2005. U-Pb SIMS dating of synkinematic granites: timing of corecomplex formation in the northern Anatolide belt of western Turkey. Journal of the Geological Society of London 162, 289-298.

Rossetti, F., Balsamo, F., Villa, I.M., Bouybaouenne, M., Faccenna, C. \& Funiciello, R., 2008. Pliocene-Pleistocene HT-LP metamorphism during multiple granitic intrusions in the southern branch of the Larderello geothermal field (southern Tuscany, Italy). Journal of the Geological Society of London 165, 247-262. 
Schmidt, M.W., 1992. Amphibole composition in tonalite as a function of pressure: an

experimental calibration of the Al-in-hornblende barometer. Contributions to Mineralogy and Petrology 110, 304-10.

Sengör, A.M.C., Satir, M., Akkök, R., 1984. Timing of the tectonic events in the Menderes massif, western Turkey: implications for tectonic evolution and evidence for Pan- African basement in Turkey. Tectonics 3, 693-707.

Seward, D., Vanderhaeghe, O., Siebenaller, L., Thomson, S., Hibsch, C., Zingg, A., Holzner, P., Ring, U., Duchêne, S., 2009. Cenozoic tectonic evolution of Naxos Island through a multifaceted approach of fission-track analysis. Geological Society, London, Special Publications 321, 179-196. doi:10.1144/SP321.9

Seyitoğlu, G., Scott, B.C., Rundle, C.C., 1992. Timing of Cenozoic extensional tectonics in west Turkey. Journal of the Geological Society of London 149, 533-538.

Seyitoğlu, G., Anderson, D., Nowell, G., Scott, B., 1997 - The evolution from Miocene potassic to Quaternary sodic magmatism in Western Turkey: implications for enrichment processes in the lithospheric mantle. Journal of Volcanology and Geothermal Research 76, 127-147.

Seyitoğlu, G., 1997. The Simav graben: an example of young E-W trending structures in the late Cenozoic extensional system of Western Turkey. Turkish Journal of Earth Sciences 6, 135141.

Spencer, K.J., Hacker, B.R., Kylander-Clark, A.R.C., Andersen, T.B., Cottle, J.M., Stearns, M.A., Poletti, J.E., Seward, G.G.E., 2013. Campaign-style titanite U-Pb dating by laserablation ICP: Implications for crustal flow, phase transformations and titanite closure. Chemical Geology 341, 84-101.

Stacey, J.S., K.ramers, J.D., 1975. Approximation of terrestrial lead isotope evolution by a twostage model. Earth and Planetary Science Letters 26, 207-221.

Stip, M., Stunitz, H., Heilbronner, R., Schmid, S.M., 2002. The eastern Tonale fault zone: a "natural laboratory" for crystal plastic deformation for quartz over a temperature range from 250 to $700^{\circ} \mathrm{C}$. Journal of Structural Geology $24,1861-1884$. 
Sun, S.S., McDonough, W.F., 1989. Chemical and isotopic systematics of oceanic basalts:

implications for mantle composition and processes. In: Sanders, A.D., Norry, M.J. (Eds.), Magmatism in the Ocean Basins. Geological Society of London Special Publication, 42, 313345.

Teyssier, C., Whitney, D.L., 2002. Gneiss domes and orogeny. Geology, v. 30, p. 1139-1142.

Thomson, S.N., Ring, U., 2006. Thermochronologic evaluation of post-collision extension in the Anatolide Orogen, western Turkey. Tectonics 25, TC3005.

Vanderhaeghe, O., Teyssier, C., 2001. Partial melting and flow of orogens. Tectonophysics 342 $451-472$.

Wernike, B., 1985. Uniform-sense normal simple shear of the continental lithosphere. Canadian Journal of Earth Sciences 22(1), 108-125.

Whitney, D.L., Evans, B.W., 2010. Abbreviations for names of rock-forming minerals. American Mineralogist 95(1), 185-187.

Whitney, D.L., Teyssier, C., Fayon, A.K., 2004. Isothermal decompression, partial melting and exhumation of deep continental crust. Geological Society, London, Special Publications 227, 313-326, doi:10.1144/GSL.SP.2004.227.01.16

Whitney, D.L., Teyssier, C., Rey, P., Buck, W.R., 2013. Continental and oceanic core complexes. Geological Society of America Bulletin 125 (3/4), 273-298.

Wintsch, R.P., Aleinikoff, J.N., Yi, K., 2005. Foliation development and reaction softening by dissolution and precipitation in the transformation of granodiorite to orthogneiss, Glastonbury Complex, Connecticut, U.S.A. The Canadian Mineralogist 43, 327-347. 


\section{Table Captions}

Table 1 - Sample location, fabrics and constituent mineralogy

Table 2a-d - Mineral chemistry

Table 3 - U-(Th)-Pb LA-ICPMS data on titanite

\section{Figure Captions}

Figure 1 - Synthetic tectonic map of southwestern Turkey showing the main tectonic structures of the Menderes Massif, with the study area indicated. The inset shows the main tectonic lineaments and the main metamorphic core complexes in the Aegean region. Abbreviations: NAF, North Anatolian Fault; EAF, East Anatolian Fault; DSF, Dead Sea Fault; HA, Hellenic Arc; CA, Cyprian Arc; RM, Rhodope Massif; CyM, Cycladic Massif; CrM, Crete Massif; KM, Kazdağ Massif; MM, Menderes Massif.

Figure 2 - (a) Equal area stereoplots (Schmidt net, lower hemisphere projections) showing the cumulative attitude of the plano-linear fabrics along the GDF. (b) Simplified structural map of the study area (modified and re-adapted after Hetzel et al. (1995a) and Işik et al. (2003) based on original field work), with distribution of the attitude of the ductile S-L tectonic fabrics recovered from the mylonitic horizons of the GDF. (c) Schematic cross-section through the GDF (see Figure $2 b$ ) with indication of the main structural fabrics and location of the studied samples; samples indicated in red are those used for the titanite $\mathrm{U}-(\mathrm{Th})-\mathrm{Pb}$ dating.

Figure 3 - Proto mylonite textures. (a) Meso-scale appearance, with secondary sub-horzontal planar banding defined by a fine-grained matrix made of quartz (light) and biotite (dark) that 
envelope mm-sized feldspar porphyroclasts (whitish). (b) Microscale appearance, showing a

preserved, well annealed igneous texture as defined by quartz-K-feldspar-plagioclase (some with oscilaltory zoning) assemblage in equilibrium with coarse-grained titanite $\left(\operatorname{Ttn}_{1}\right)$. Evidence of solid-state deformation is attested by serrated grain boundaries and aggregates of fine-grained recrystallised quartz and foliated of newly formed biotite $\left(\mathrm{Bt}_{2}\right)$. Sample T14-09 (crossed polars).

Figure 4 - Mylonite textures as observed in sections cut parallel to the stretching direction and normal to shear foliation (X-Z sections of the finite strain ellipse). (a) Mesoscale appearance, showing a pronounced $\mathrm{C}$ shear band cleavage defined by fine-grained quartz-biotite folia. Sigma-type feldspar porphyroclasts and the S-C fabrics indicate sinistral (top-to-the-NNE) sense of shear. (b) Sigma- type feldspar porphyroclasts embedded in a high strained, recrystallised oblique foliation made of ribbon quartz and secondary biotite $\left(\mathrm{Bt}_{2}\right)$. Shear sense sinistral. Feldspar grains show evidence of heterogeous strain as attested by healed microcracks, undulose extinction and incipient recrystallisation (dominantly assisted by bulging) and subgrain formation at grain boundaries (white arrows in $\mathrm{Pl}_{1}$ ). Sample T14-06 (crossed polars). (c) Asymmetric boundinage of magmatic titanite $\left(\mathrm{Ttn}_{1}\right)$, embedded within the mylonitic foliation defined by ribbon quartz and secondary biotite $\left(\mathrm{Bt}_{2}\right)$. Shear sense sinistral. Porphyroclastic feldspar grains show evidence of recrystallisation with formation of subgrains and fine-grained mantle structures (white arrows). Sample T14-06 (crossed polars). (d) Enlargement of the area indicated in (c) showing sigma-type and boudinaged $\mathrm{Ttn}_{1}$ grains. The quartz fabric is dominated by small dynamically recrystallized grains, probably produced by subgrain rotation recrystallization. Domains of polycrystalline quartz with irregular grain boundaries formed in response to grain boundary migration are also observed (white arrows). Note the subgrain formation at the grain boundaries in $\mathrm{Pl}_{1}$ (crossed polars). (e) Overgrowth of secondary plagioclase $\left(\mathrm{Pl}_{2}\right)$ onto a pristine igneous plagioclase grain $\left(\mathrm{Pl}_{1}\right)$. Healed microcracks occur at the core of the igneous $\mathrm{Pl}_{1}$ grain. Crossed polars. Sample T14-06 (crossed polars). (f) Hornblende $\left(\mathrm{Amp}_{1}\right)$ and biotite $\left(\mathrm{Bt}_{1}\right)$ fishes indicating sinistral shear. Secondary (syn-shearing) amphibole 
(actinolite; $\left.\mathrm{Amp}_{2}\right)$ and biotite $\left(\mathrm{Bt}_{2}\right)$ growth is associated with solid-state deformation. Sample T14-06 (natural light).

Figure 5 - (a) Euhedral titanite $\left(\mathrm{Ttn}_{1}\right)$ grain in a recrystallised quartz-feldspar matrix. The circles indicate the laser ablation spots used for U-(Th)-Pb dating (sample T14-09; crossed polars). (b) BSE image showing a large, fractured titanite grain in equilibrium texture with the igneous assemblage made of $\mathrm{Pl}_{1}-\mathrm{Amp}_{1}-\mathrm{Bt}_{1}-\mathrm{Kfsp}-\mathrm{Qz}$. Secondary, syn-shearing matrix forming biotite $\left(\mathrm{Bt}_{2}\right)$ also occurs. (c) BSE image of $\mathrm{Ttn}_{1}$ grain shown in (b) displaying oscillatory zoned cores ( $\operatorname{Ttn}_{1}$; richer in REE) and metamorphic nearly homogeneous overgrowths ( $\operatorname{Ttn}_{2}$; poorer in REE). The white points (numbered as 1 to 12 ) indicate the EMPA compositional line traverse shown in (e). (d) Secondary titanite $\left(\mathrm{Ttn}_{2}\right)$ - biotite $\left(\mathrm{Bt}_{2}\right)$ associations growing at the expenses of an igneous biotite $\left(\mathrm{Bt}_{1}\right)$-hornblende $\left(\mathrm{Amp}_{1}\right)$ - titanite $\left(\mathrm{Ttn}_{1}\right)$ assemblage. EMPA points (numbered as 1 to 8 ) are indicated in white. Sample T14-06 (natural light). (e) EMPA composition profile of the titanite grain shown in (b). (f) EMPA compositional data of the titanite grains shown in (d).

Figure 6 - Tera-Wasserburg Concordia diagrams of not common $\mathrm{Pb}$ corrected data from titanites of the two samples. Probability density distributions of the common $\mathrm{Pb}$ corrected ${ }^{206} \mathrm{~Pb} /{ }^{238} \mathrm{U}$ ages are also shown.

Figure 7 - Left: Plot of the cumulative common $\mathrm{Pb}$ corrected ${ }^{206} \mathrm{~Pb} /{ }^{238} \mathrm{U}$ ages vs. the $\mathrm{Th} / \mathrm{U}$ data for the studied titanite grains. Right: BSE image showing comparison of ${ }^{206} \mathrm{~Pb} /{ }^{238} \mathrm{U}$ ages and Th/U zoning in a titanite grain from sample T14-06.

Figure 8 - Temperature-time (T- $t$ ) evolution of the Salihli granodiorite (footwall of the Gediz detachment fault). Time and temperature constrains are from: (1) Hetzel et al., 1995a $\left({ }^{40} \mathrm{Ar} /{ }^{39} \mathrm{Ar}\right.$ on biotite); (2) ZFT: Gessner et al. (2001), Ring et al. (2003), Buscher et al. (2013); (3) ZHe: Buscher et al. (2013); (4) AFT: Gessner et al. (2001), Ring et al. (2003), Buscher et al. (2013); (5) AHe: Buscher et al. (2013). 
Figure 9 - Conceptual tectonic model for development of the Gediz Detachment Fault (GDF) during the segregation, crystallisation and emplacement of the Sahlili granodiorite (modified and re-adapted after Rey et al., 2001; Whitney et al., 2013). Magma emplacement at shallow crustal levels during continuous magma underplating at depth caused the transient, local rise of the regional brittle-ductile transition (BDT), favoured strain softening and promoted the ductile shear strain localisation along the GDF. 


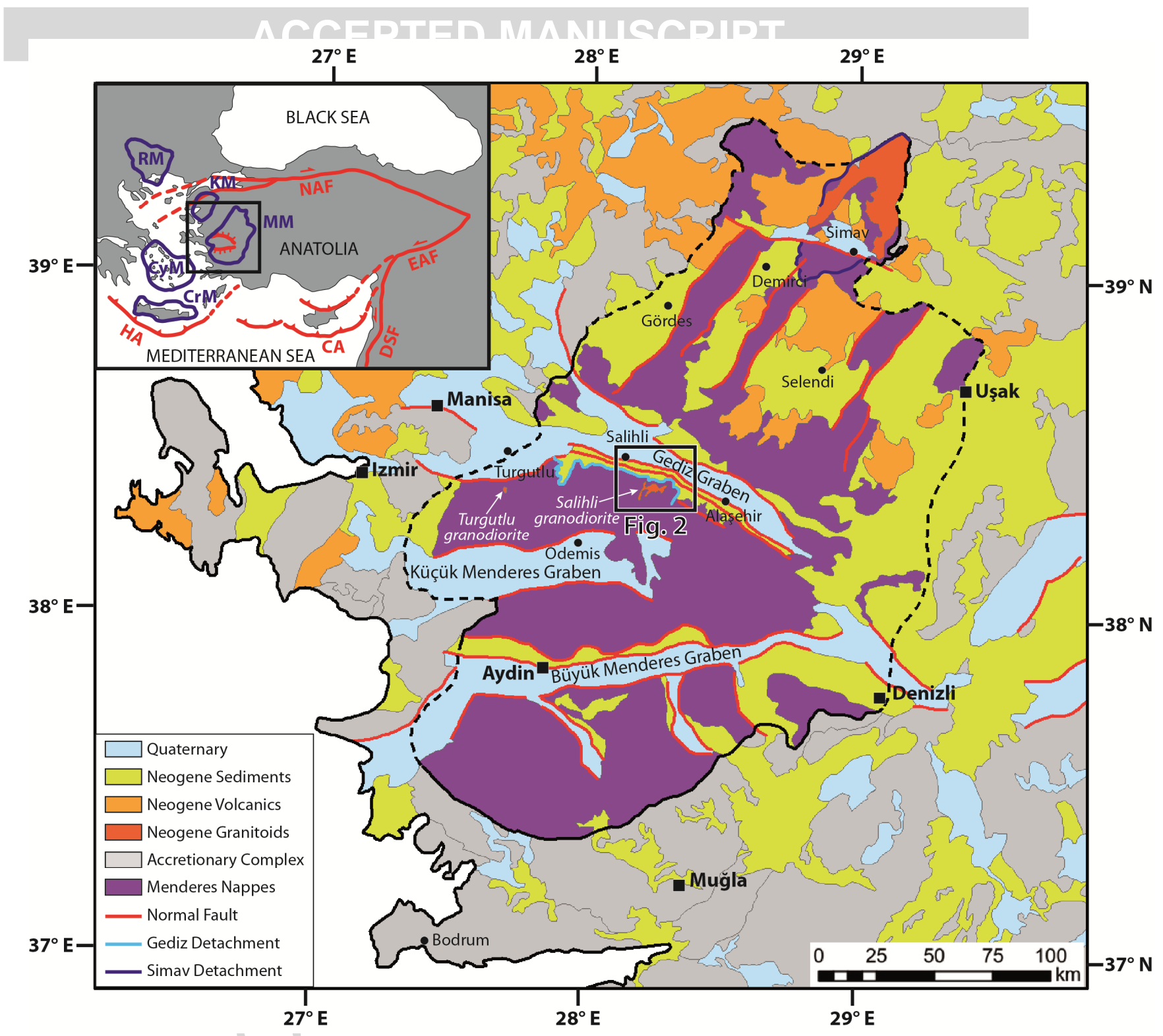

Figure 1 


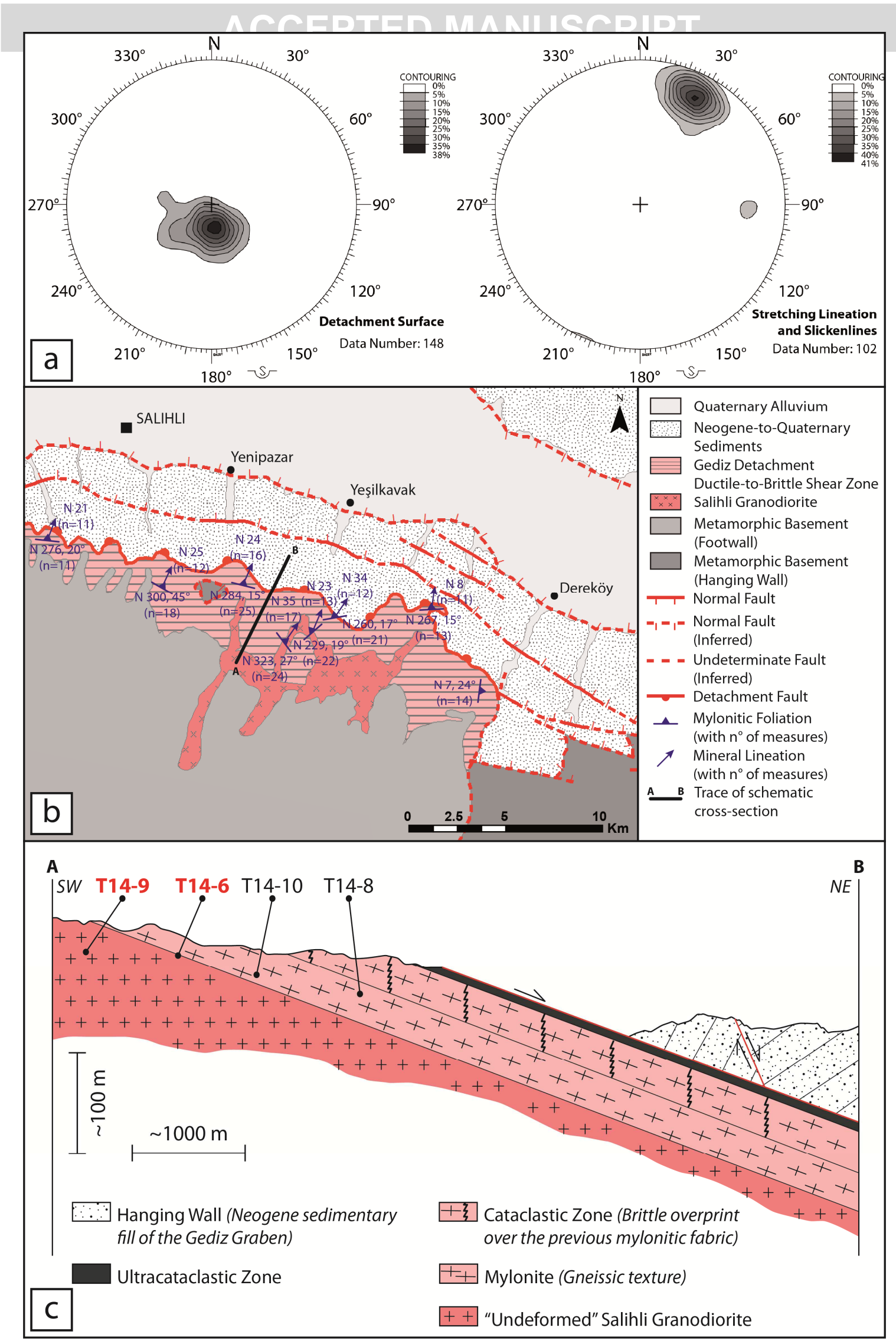

Figure 2 


\section{ACPEDTHER M/ANITCODIDTH}

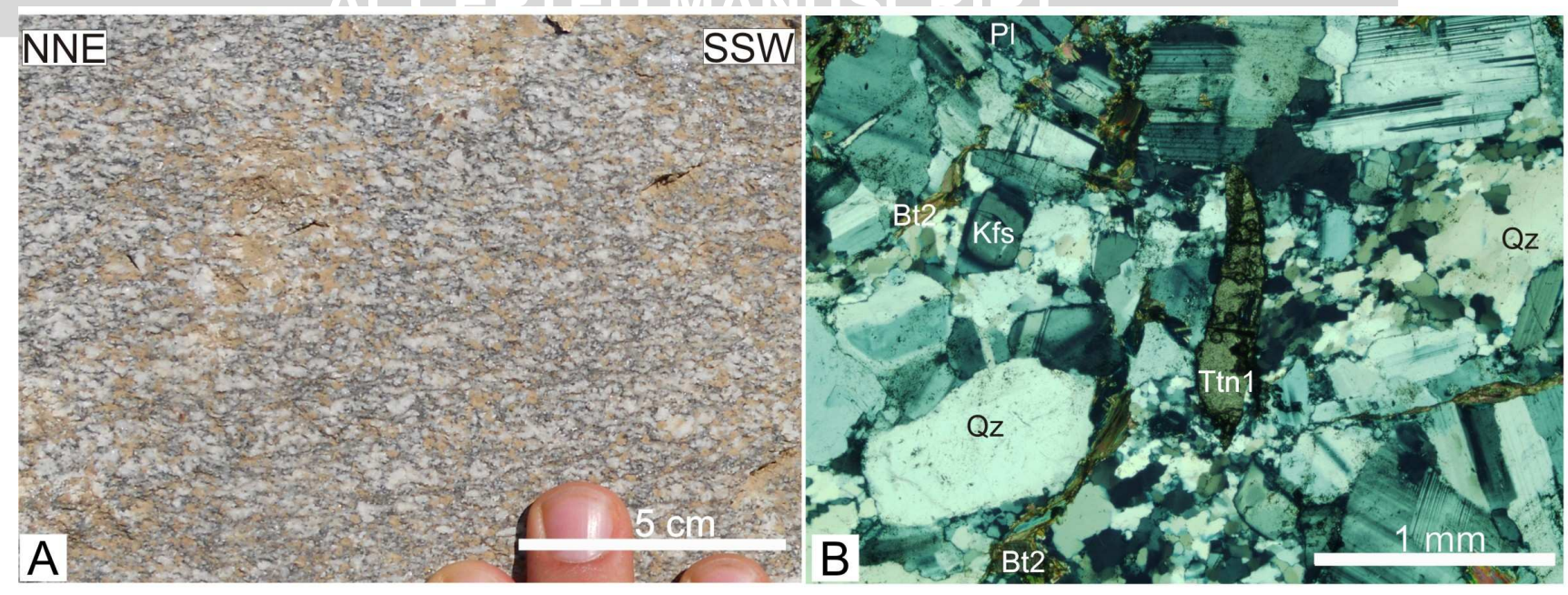

Figure 3

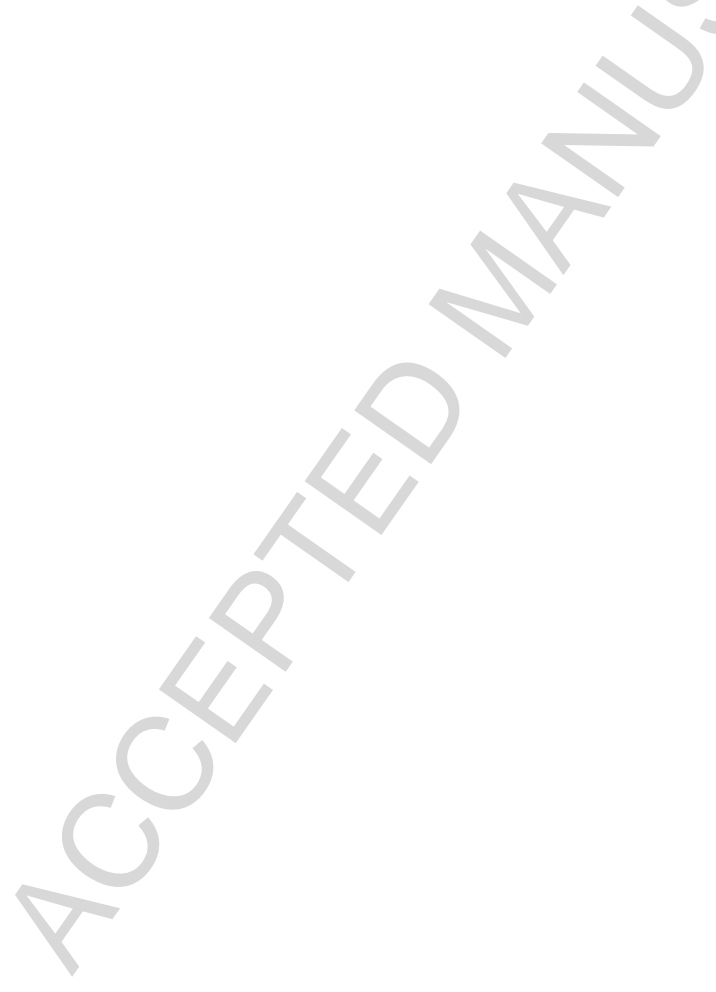




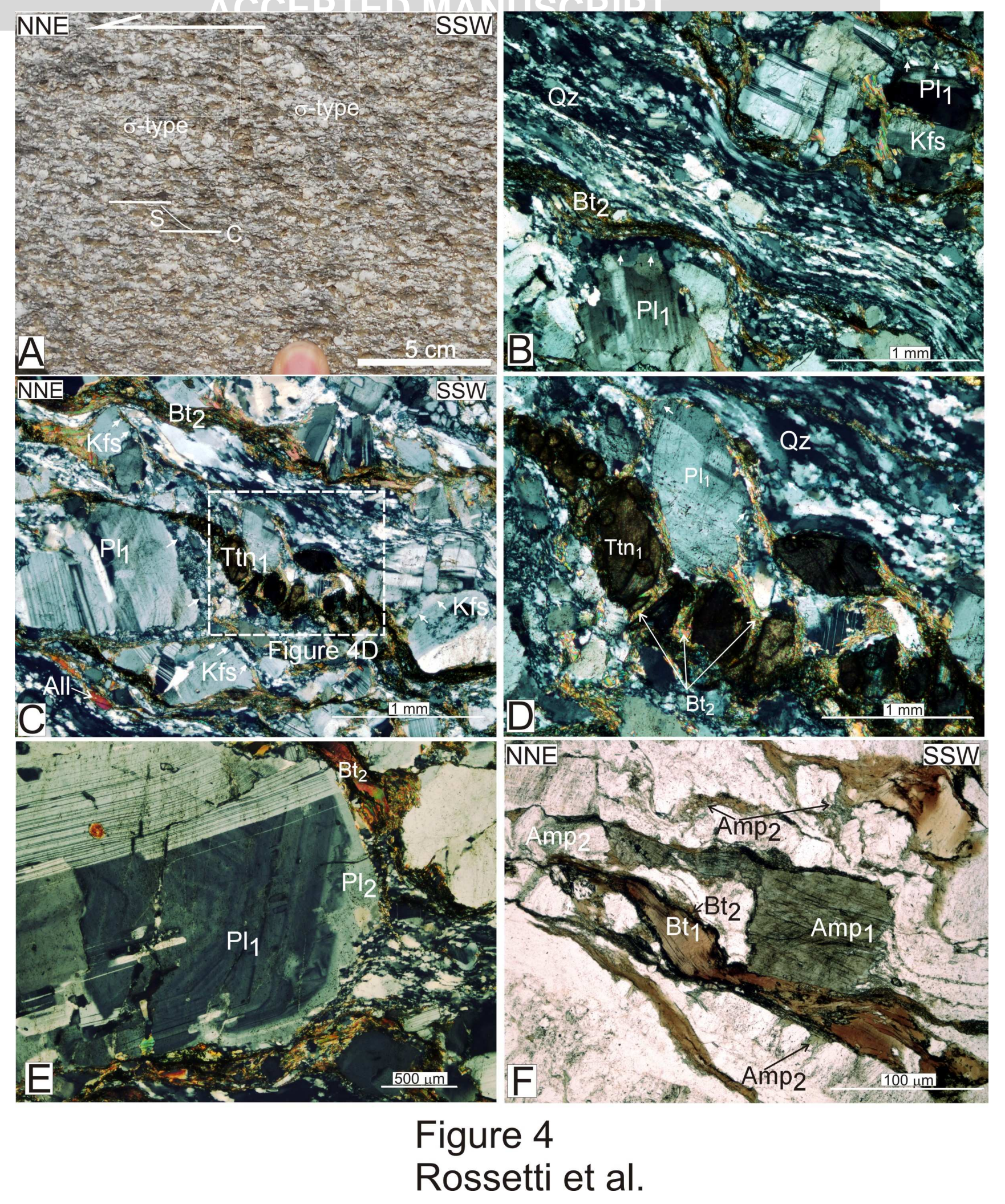




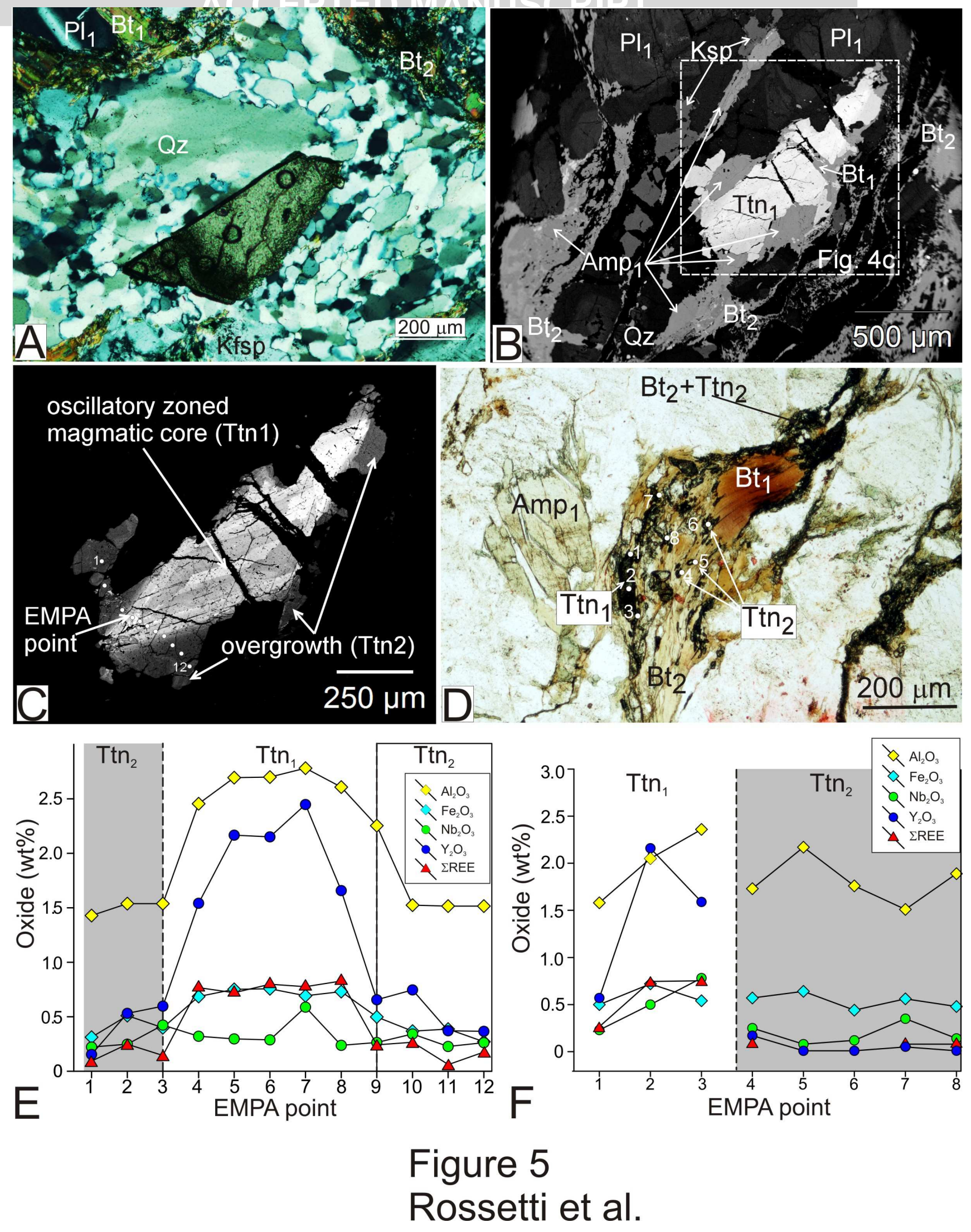



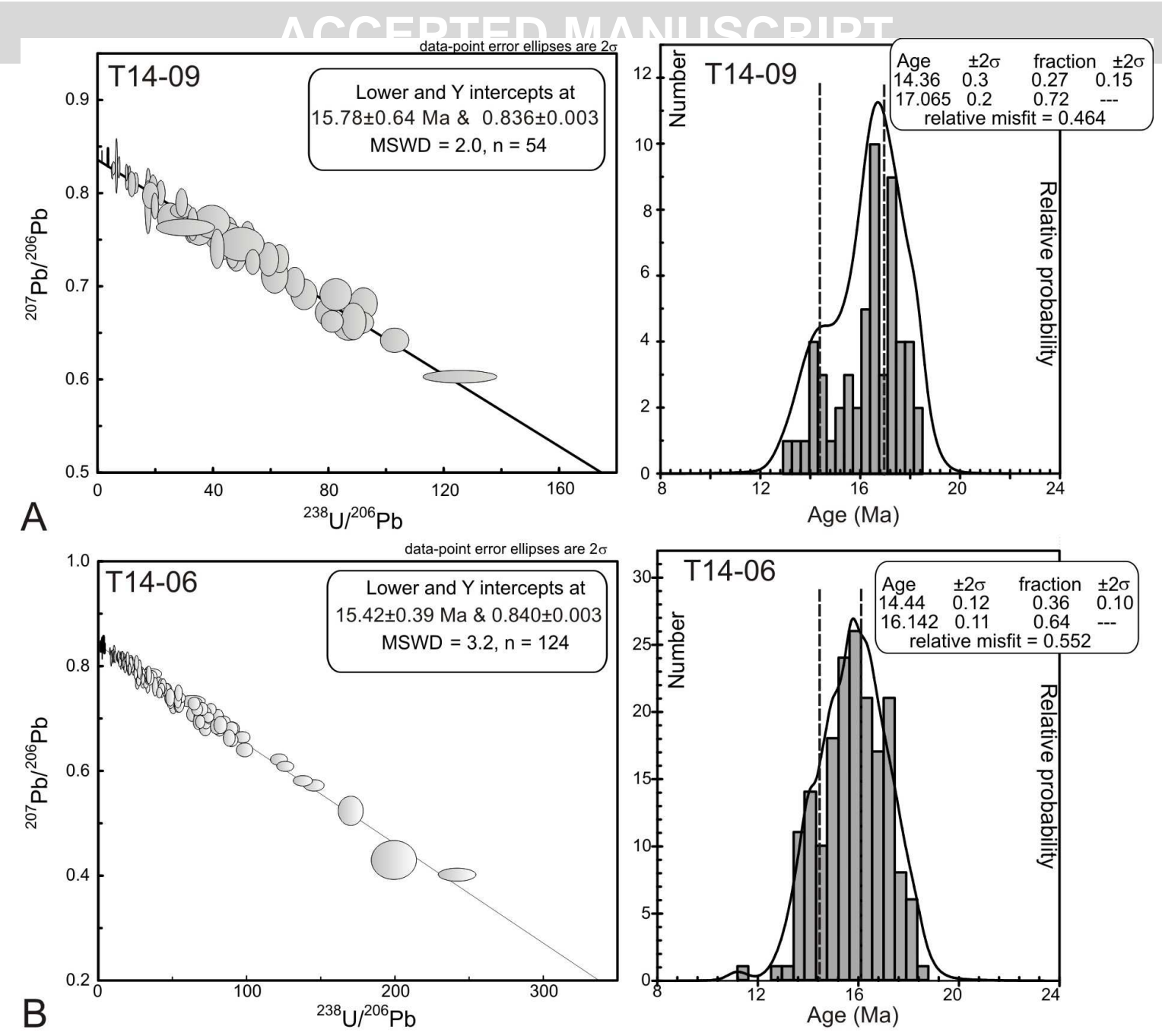

Figure 6 

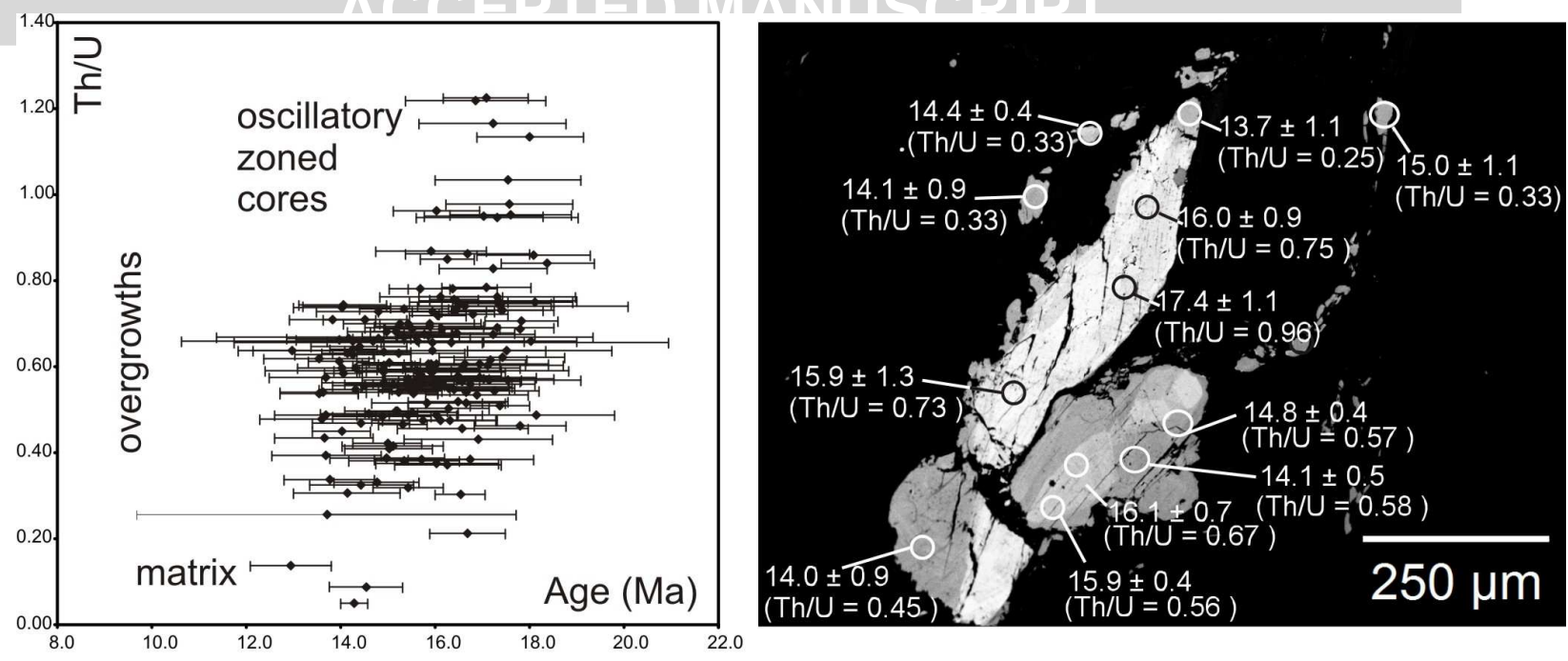

Figure 7 


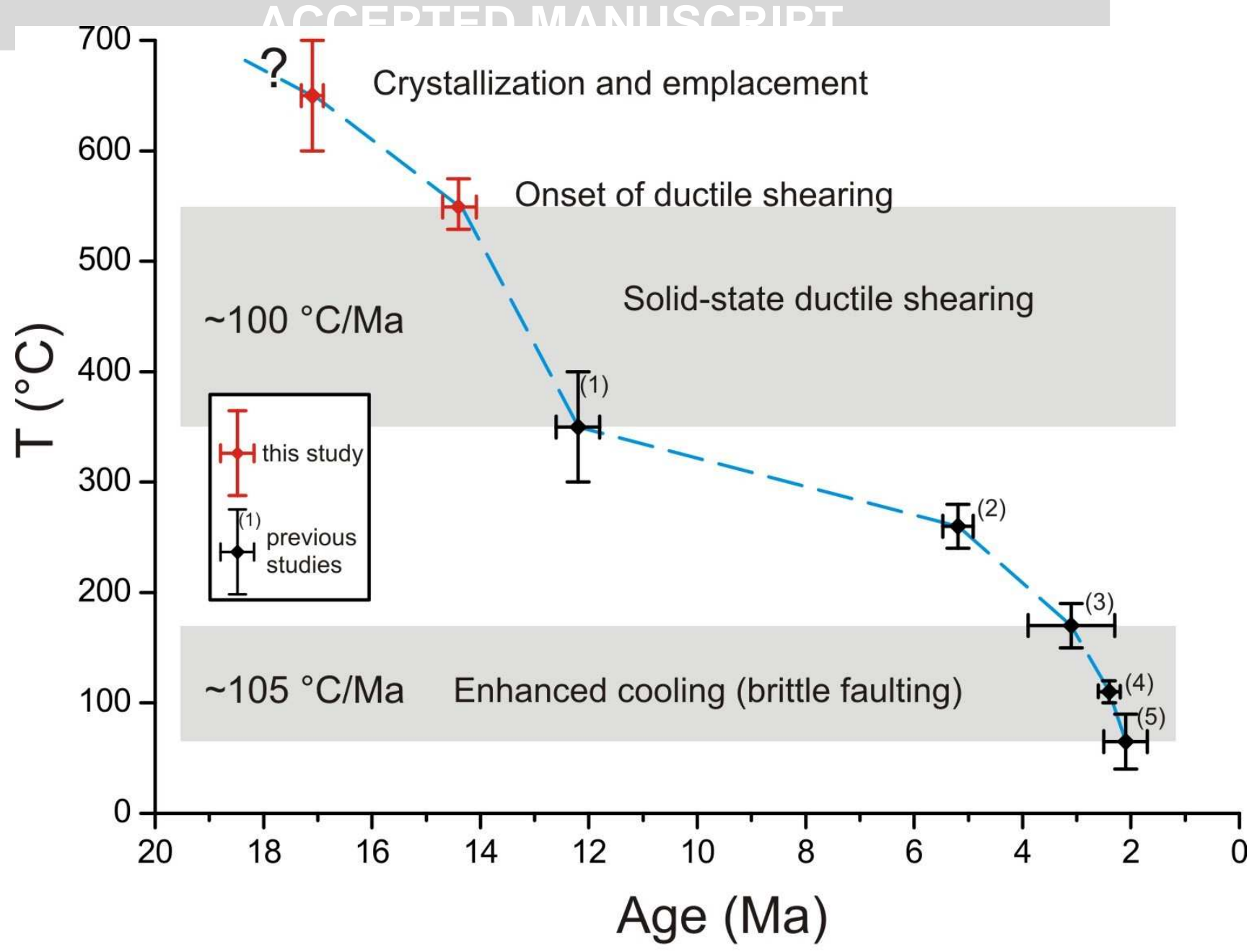

Figure 8 


\section{Early Miocene}

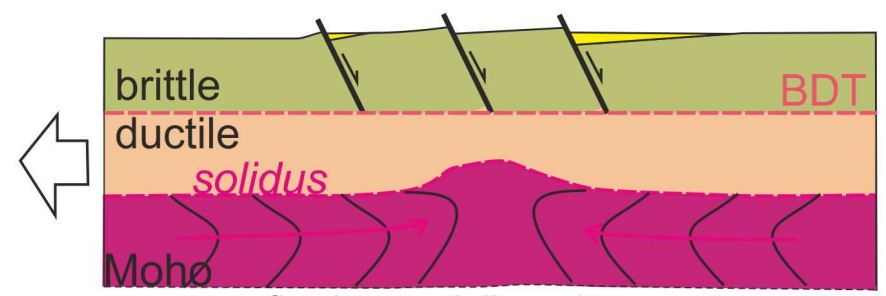

Regional extension and crustal thinning

flowing partially molten crust
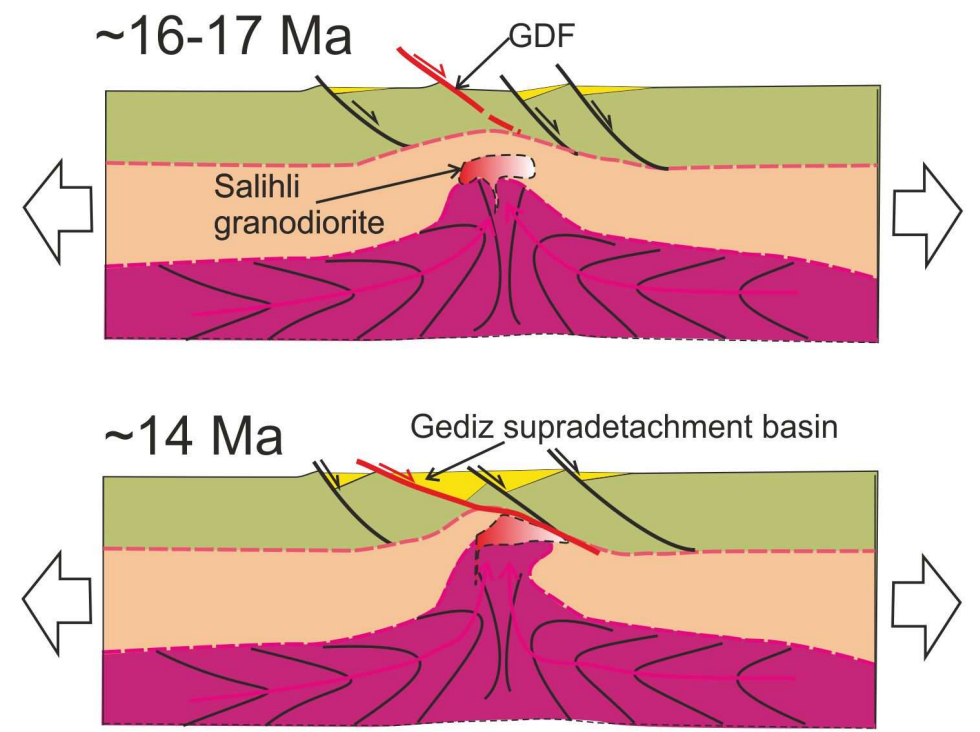

Segregation of the Salihli granodiorite, transient BDT and progressive enucleation of the GDF

\section{Middle Miocene}

Localisation of ductile shearing along the GDF and shearing of the Salihli granodiorite

\section{Late Miocene-Pliocene}

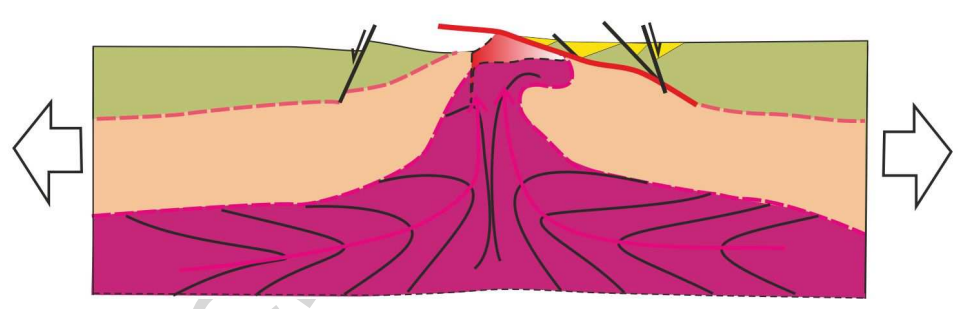

Brittle faulting and final exhumationof the GDF and Salihli granodiorite

Figure 9 
Table 1 - Location of selected samples with constituent mineralogy and analytical technique adopted

\begin{tabular}{|c|c|c|c|c|c|c|}
\hline Sample & Latitude & Longitude & Structural fabric & Mineral assemblage & EMPA & $\begin{array}{l}\text { Ttn U-(Th)- } \mathrm{Pb} \\
\text { geochronology }\end{array}$ \\
\hline T14-6 & $\begin{array}{l}\text { N 38 } 25^{\prime} \\
13.7^{\prime \prime} \\
\text { N } 38^{\circ} 24^{\prime}\end{array}$ & 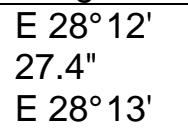 & $\begin{array}{l}\text { S-L tectonite } \\
\text { (mylonite) } \\
\text { S-L tectonite }\end{array}$ & $\begin{array}{l}\text { Qz-Fsp-Pl-Bt-Amp + IIm + Ttn + All + Ap + } \\
\text { Zrc }\end{array}$ & $X$ & $X$ \\
\hline $\mathrm{T} 14-8$ & $\begin{array}{l}00.6^{\prime \prime} \\
\text { N } 38^{\circ} 24^{\prime}\end{array}$ & $\begin{array}{l}25.9^{\prime \prime} \\
E 28^{\circ} 13^{\prime}\end{array}$ & (mylonite) & $\begin{array}{l}\text { Qz-Fsp-Pl-Bt-Amp + IIm + Ttn }+ \text { Ap }+ \text { Zrc } \\
\text { Qz-Fsp-Pl-Bt-Amp + IIm + Ttn + All + Ap + }\end{array}$ & $X$ & \\
\hline T14-9 & $\begin{array}{l}10.0^{\prime \prime} \\
\text { N } 38^{\circ}\end{array}$ & $\begin{array}{l}37.6^{\prime \prime} \\
E 28^{\circ} 14^{\prime}\end{array}$ & protomylonite & $\mathrm{Zrc}$ & $X$ & $X$ \\
\hline T14-10 & 24'22.7" & $01.6 "$ & protomylonite & Qz-Fsp-PI-Bt-Amp + IIm + Ap + Zrc & $X$ & \\
\hline
\end{tabular}


Table 2a - Representative EMPA and chemical formulas of feldspar

\begin{tabular}{|c|c|c|c|c|c|c|c|c|c|c|}
\hline Sample & T14-9 & T14-9 & T14-6 & T14-6 & T14-6 & T14-6 & T14-9 & T14-6 & T14-6 & T14-6 \\
\hline \multirow[t]{2}{*}{ Mineral } & \multicolumn{8}{|c|}{ Plagioclase } & \multicolumn{2}{|c|}{ K-feldspar } \\
\hline & \multicolumn{4}{|c|}{ PI1 - Core } & \multicolumn{2}{|c|}{ PI1 - Rim } & \multicolumn{2}{|c|}{$\begin{array}{c}\mathrm{PI} 2- \\
\text { overgrowth }\end{array}$} & & \\
\hline Point No. & $\# 5$ & $\# 6$ & $\# 32$ & \#39 & $\# 37$ & \#91 & \#3 & $\# 44$ & $\# 30$ & $\# 87$ \\
\hline $\mathrm{SiO}_{2}$ & 50.95 & 51.17 & 55.39 & 57.44 & 59.74 & 60.47 & 61.65 & 62.42 & 64.23 & 65.06 \\
\hline $\mathrm{Al}_{2} \mathrm{O}_{3}$ & 31.33 & 30.70 & 28.63 & 27.33 & 25.77 & 25.62 & 24.14 & 24.17 & 18.52 & 18.43 \\
\hline FeOt & 0.05 & 0.04 & 0.04 & 0.04 & 0.12 & 0.01 & 0.00 & 0.20 & 0.00 & 0.01 \\
\hline $\mathrm{CaO}$ & 13.59 & 13.54 & 10.50 & 8.88 & 7.05 & 6.73 & 5.23 & 5.44 & 0.00 & 0.03 \\
\hline $\mathrm{Na}_{2} \mathrm{O}$ & 3.80 & 3.90 & 5.44 & 6.39 & 7.27 & 7.48 & 8.48 & 8.43 & 0.61 & 0.96 \\
\hline $\mathrm{K}_{2} \mathrm{O}$ & 0.10 & 0.15 & 0.10 & 0.09 & 0.11 & 0.08 & 0.22 & 0.14 & 16.34 & 15.30 \\
\hline $\mathrm{BaO}$ & 0.02 & 0.02 & bdl & bdl & 0.01 & 0.02 & bdl & bdl & 0.42 & 0.47 \\
\hline Total & 99.83 & 99.51 & 100.09 & 100.17 & 100.07 & 100.42 & 99.72 & 100.81 & 100.13 & 100.24 \\
\hline \multicolumn{11}{|c|}{ Formula (8 Oxygens) } \\
\hline Si (apfu) & 2.32 & 2.34 & 2.49 & 2.57 & 2.66 & 2.68 & 2.74 & 2.74 & 2.98 & 3.00 \\
\hline Al & 1.68 & 1.65 & 1.52 & 1.44 & 1.35 & 1.34 & 1.26 & 1.25 & 1.01 & 1.00 \\
\hline $\mathrm{Ba}$ & 0.00 & 0.00 & 0.00 & 0.00 & 0.00 & 0.00 & 0.00 & 0.00 & 0.01 & 0.01 \\
\hline $\mathrm{Ca}$ & 0.66 & 0.66 & 0.51 & 0.43 & 0.34 & 0.32 & 0.25 & 0.26 & 0.00 & 0.00 \\
\hline $\mathrm{Na}$ & 0.34 & 0.35 & 0.47 & 0.55 & 0.63 & 0.64 & 0.73 & 0.72 & 0.05 & 0.09 \\
\hline K & 0.01 & 0.01 & 0.01 & 0.01 & 0.01 & 0.00 & 0.01 & 0.01 & 0.97 & 0.90 \\
\hline An & 0.66 & 0.65 & 0.51 & 0.43 & 0.35 & 0.33 & 0.25 & 0.26 & 0.01 & 0.99 \\
\hline$A b$ & 0.33 & 0.34 & 0.48 & 0.56 & 0.65 & 0.66 & 0.74 & 0.73 & 0.09 & 0.09 \\
\hline Or & 0.01 & 0.01 & 0.01 & 0.01 & 0.01 & 0.00 & 0.01 & 0.01 & 0.90 & 0.90 \\
\hline
\end{tabular}




\begin{tabular}{|c|c|c|c|c|c|c|c|}
\hline \multirow{2}{*}{$\begin{array}{l}\text { Sample } \\
\text { Mineral }\end{array}$} & T14-9 & T14-6 & T14-6 & T14-6 & & T14-9 & T14-6 \\
\hline & \multicolumn{4}{|c|}{ Biotite } & & \multicolumn{2}{|c|}{ Epidote } \\
\hline \multirow[b]{2}{*}{ Point No. } & \multicolumn{2}{|c|}{ Bt1 } & \multicolumn{2}{|c|}{$\mathrm{Bt} 2$} & & \multirow[b]{2}{*}{$\# 28$} & \multirow[b]{2}{*}{ \#51 } \\
\hline & $\# 10$ & $\# 76$ & $\# 48$ & $\# 58$ & & & \\
\hline $\mathrm{SiO}_{2}$ & 36.10 & 36.76 & 37.44 & 36.09 & $\mathrm{SiO}_{2}$ & 39.44 & 38.73 \\
\hline $\mathrm{TiO}_{2}$ & 2.69 & 3.02 & 0.29 & 1.06 & $\mathrm{TiO}_{2}$ & 0.11 & 0.13 \\
\hline $\mathrm{Al}_{2} \mathrm{O}_{3}$ & 15.91 & 16.16 & 18.50 & 18.41 & $\mathrm{Al}_{2} \mathrm{O}_{3}$ & 27.19 & 27.84 \\
\hline FeOt & 20.81 & 19.98 & 17.63 & 17.99 & $\mathrm{FeOt}$ & 6.94 & 6.26 \\
\hline $\mathrm{MnO}$ & 0.39 & 0.34 & 0.32 & 0.39 & $\mathrm{MnO}$ & 0.17 & 0.22 \\
\hline $\mathrm{MgO}$ & 9.08 & 9.40 & 10.35 & 9.33 & $\mathrm{MgO}$ & 0.03 & bdl \\
\hline $\mathrm{CaO}$ & 0.03 & 0.01 & 0.01 & 0.03 & $\mathrm{CaO}$ & 23.48 & 23.06 \\
\hline $\mathrm{Na}_{2} \mathrm{O}$ & 0.14 & 0.09 & 0.04 & 0.04 & $\mathrm{Na}_{2} \mathrm{O}$ & 0.03 & 0.02 \\
\hline $\mathrm{K}_{2} \mathrm{O}$ & 9.59 & 9.80 & 9.58 & 9.82 & $\mathrm{~K}_{2} \mathrm{O}$ & 0.07 & bdl \\
\hline $\mathrm{BaO}$ & 0.39 & 0.22 & bdl & 0.03 & $\mathrm{BaO}$ & 0.02 & 0.01 \\
\hline Total & 95.12 & 95.77 & 94.16 & 93.18 & Total & 97.50 & 96.27 \\
\hline \multicolumn{5}{|c|}{ Formula (11 Oxygens) } & \multicolumn{3}{|c|}{ Formula (12.5 Oxygens) } \\
\hline Si (apfu) & 2.79 & 2.81 & 2.85 & 2.80 & Si (apfu) & 3.06 & 3.03 \\
\hline Al_T & 1.21 & 1.19 & 1.15 & 1.20 & $\mathrm{Ti}$ & 0.01 & 0.01 \\
\hline $\mathrm{Ti}$ & 0.16 & 0.17 & 0.02 & 0.06 & $\mathrm{Al}$ & 2.48 & 2.57 \\
\hline Al_O & 0.25 & 0.26 & 0.51 & 0.48 & $\mathrm{Fe} 3$ & 0.45 & 0.41 \\
\hline Fe2 & 1.35 & 1.28 & 1.12 & 1.17 & $\mathrm{Mg}$ & 0.00 & 0.00 \\
\hline $\mathrm{Mn}$ & 0.03 & 0.02 & 0.02 & 0.03 & $\mathrm{Mn}$ & - & - \\
\hline $\mathrm{Mg}$ & 1.05 & 1.07 & 1.17 & 1.08 & $\mathrm{Ca}$ & 1.95 & 1.93 \\
\hline $\mathrm{Ca}$ & - & - & - & - & $\mathrm{Na}$ & - & - \\
\hline $\mathrm{Na}$ & 0.02 & 0.01 & 0.01 & 0.01 & K & - & - \\
\hline K & 0.95 & 0.95 & 0.93 & 0.97 & $\mathrm{Ba}$ & - & - \\
\hline $\mathrm{Ba}$ & 0.01 & 0.01 & - & - & & & \\
\hline XAl & 0.12 & 0.13 & 0.25 & 0.24 & $\mathrm{XFe}$ & 0.15 & 0.14 \\
\hline
\end{tabular}


Table 2c. Representative EMPA and chemical formulas of amphiboles with results of the Hbl-PI thermobarometry

\begin{tabular}{|c|c|c|c|c|c|c|c|c|}
\hline \multirow[t]{2}{*}{ Sample } & T14-6 & T14-6 & T14-9 & T14-9 & T14-6 & T14-6 & T14-6 & T14-6 \\
\hline & \multicolumn{4}{|c|}{ Amph1 } & \multicolumn{4}{|c|}{ Amph2 } \\
\hline Point No. & $\# 25$ & $\# 64$ & $\# 67$ & $\# 68$ & $\# 40$ & \#46 & $\# 69$ & $\# 89$ \\
\hline $\mathrm{SiO}_{2}$ & 49.71 & 48.50 & 49.44 & 49.40 & 51.18 & 51.62 & 50.84 & 50.95 \\
\hline $\mathrm{TiO}_{2}$ & 0.65 & 0.68 & 0.62 & 0.62 & 0.19 & 0.25 & 0.23 & 0.18 \\
\hline $\mathrm{Al}_{2} \mathrm{O}_{3}$ & 5.47 & 5.90 & 5.82 & 5.34 & 4.26 & 4.48 & 4.34 & 4.62 \\
\hline FeOt & 16.48 & 16.09 & 15.76 & 15.42 & 15.71 & 15.60 & 14.95 & 15.15 \\
\hline $\mathrm{MnO}$ & 0.67 & 0.66 & 0.62 & 0.62 & 0.59 & 0.62 & 0.58 & 0.64 \\
\hline $\mathrm{MgO}$ & 11.53 & 11.34 & 11.24 & 11.86 & 12.38 & 12.26 & 12.23 & 12.17 \\
\hline $\mathrm{CaO}$ & 11.81 & 11.16 & 11.29 & 11.29 & 11.96 & 12.07 & 11.66 & 11.98 \\
\hline $\mathrm{Na}_{2} \mathrm{O}$ & 0.63 & 0.76 & 0.61 & 0.64 & 0.45 & 0.53 & 0.38 & 0.45 \\
\hline $\mathrm{K}_{2} \mathrm{O}$ & 0.54 & 0.54 & 0.50 & 0.50 & 0.33 & 0.34 & 0.35 & 0.36 \\
\hline Total & 97.49 & 95.63 & 95.91 & 95.71 & 97.05 & 97.77 & 95.56 & 96.50 \\
\hline \multicolumn{9}{|c|}{ Formula: $23(0)^{(*)}$} \\
\hline Al(total) & 0.951 & 1.044 & 1.026 & 0.942 & 0.739 & 0.772 & 0.764 & 0.805 \\
\hline $\mathrm{Si}(\mathrm{T})$ & 7.34 & 7.29 & 7.39 & 7.39 & 7.54 & 7.54 & 7.59 & 7.54 \\
\hline $\mathrm{Al}^{\mathrm{iv}}(\mathrm{T})$ & 0.66 & 0.71 & 0.61 & 0.61 & 0.46 & 0.46 & 0.41 & 0.46 \\
\hline \multicolumn{9}{|c|}{ M1,2,3 sites } \\
\hline $\mathrm{Al}^{\mathrm{vi}}$ & 0.29 & 0.33 & 0.42 & 0.33 & 0.28 & 0.31 & 0.35 & 0.34 \\
\hline $\mathrm{Ti}$ & 0.07 & 0.08 & 0.07 & 0.07 & 0.02 & 0.03 & 0.03 & 0.02 \\
\hline $\mathrm{Fe}^{3+}$ & 0.19 & 0.21 & 0.08 & 0.14 & 0.13 & 0.11 & 0.03 & 0.09 \\
\hline $\mathrm{Mg}$ & 2.54 & 2.54 & 2.50 & 2.64 & 2.72 & 2.67 & 2.72 & 2.68 \\
\hline $\mathrm{Mn}$ & 0.08 & 0.08 & 0.08 & 0.08 & 0.07 & 0.08 & 0.07 & 0.08 \\
\hline
\end{tabular}




\begin{tabular}{|c|c|c|c|c|c|c|c|c|c|c|}
\hline $\mathrm{Fe}^{2+}$ & & 1.83 & 1.76 & 1.85 & 1.74 & & 1.78 & 1.80 & 1.80 & 1.79 \\
\hline $\mathrm{Ca}$ & & 0.00 & 0.00 & 0.00 & 0.00 & & 0.00 & 0.01 & 0.00 & 0.00 \\
\hline \multicolumn{11}{|l|}{ M4 site } \\
\hline $\mathrm{Fe}$ & & 0.01 & 0.05 & 0.04 & 0.05 & & 0.03 & 0.00 & 0.04 & 0.00 \\
\hline $\mathrm{Ca}$ & & 1.87 & 1.80 & 1.81 & 1.81 & & 1.89 & 1.88 & 1.86 & 1.90 \\
\hline $\mathrm{Na}$ & & 0.12 & 0.15 & 0.15 & 0.14 & & 0.09 & 0.12 & 0.10 & 0.10 \\
\hline \multicolumn{11}{|l|}{ A site } \\
\hline $\mathrm{Ca}$ & & 0.00 & 0.00 & 0.00 & 0.00 & & 0.00 & 0.00 & 0.00 & 0.00 \\
\hline $\mathrm{Na}$ & & 0.06 & 0.07 & 0.03 & 0.05 & & 0.04 & 0.03 & 0.01 & 0.03 \\
\hline K & & 0.10 & 0.10 & 0.10 & 0.10 & & 0.06 & 0.06 & 0.07 & 0.07 \\
\hline Sum A & & 0.16 & 0.17 & 0.12 & 0.14 & & 0.10 & 0.10 & 0.08 & 0.10 \\
\hline \multicolumn{11}{|l|}{$\mathrm{OH}$ site } \\
\hline $\mathrm{OH}$ & & 2.00 & 2.00 & 2.00 & 2.00 & & 2.00 & 2.00 & 2.00 & 2.00 \\
\hline Sum cations & & 15.16 & 15.17 & 15.12 & 15.14 & & 15.10 & 15.10 & 15.08 & 15.10 \\
\hline IMA-04 & \multicolumn{6}{|c|}{ Mg-hornblende } & \multicolumn{4}{|c|}{ Actinolite } \\
\hline \multicolumn{11}{|l|}{$P(A l-i n-H b l)$} \\
\hline (kbar) & & 1.52 & 1.96 & 1.87 & 1.47 & & 0.51 & 0.67 & 0.63 & 0.82 \\
\hline $\mathrm{T}\left(\mathrm{Ti}\right.$-in-Hbl) $\left({ }^{\circ} \mathrm{C}\right)$ & & 631 & 638 & 629 & 629 & & 570.61 & 578.34 & 575.68 & 569.51 \\
\hline $\mathrm{P}$ (Hbl-PI) (kbar) & [XAn 35\%] & 1.66 & 2.13 & 1.97 & 1.60 & [XAn 25\%] & n.v. & n.v. & n.v. & n.v. \\
\hline $\mathrm{T}(\mathrm{Hbl}-\mathrm{Pl})\left({ }^{\circ} \mathrm{C}\right)$ & [XAn 35\%] & 623 & 632 & 590 & 616 & [XAn 25\%] & 553 & 556 & 531 & 539 \\
\hline
\end{tabular}

(*) Amphibole formula and P-T models recalculated with "Plagioclase-Hornblende Thermobarometry" Excel spreadsheet in Anderson et al (2008). 
Table2d - Representative EMPA and chemical formulas of Titanite with results of the Zr-in Ttn thermobarometry

\begin{tabular}{|c|c|c|c|c|c|c|c|c|c|c|c|c|c|c|c|c|c|}
\hline \multirow[t]{2}{*}{ Sample } & T14-6 & T14-6 & T14-6 & T14-6 & T14-6 & T14-6 & T14-6 & T14-9 & $\begin{array}{l}\text { T14- } \\
9 \\
\end{array}$ & $\begin{array}{l}\text { T14- } \\
6 \\
\end{array}$ & $\begin{array}{l}\text { T14- } \\
6 \\
\end{array}$ & $\begin{array}{l}\text { T14- } \\
6 \\
\end{array}$ & $\begin{array}{l}\text { T14- } \\
6 \\
\end{array}$ & $\begin{array}{l}\text { T14- } \\
6\end{array}$ & $\begin{array}{l}\text { T14- } \\
6 \\
\end{array}$ & $\begin{array}{l}\text { T14- } \\
6 \\
\end{array}$ & $\begin{array}{l}\text { T14- } \\
6 \\
\end{array}$ \\
\hline & \multicolumn{9}{|c|}{ Magmatic Cores } & \multicolumn{8}{|c|}{ Metamorphic Rim (overgrowth), Matrix } \\
\hline \multirow[t]{2}{*}{ Point No. } & $\# 3$ & $\# 5$ & $\# 6$ & $\# 7$ & $\# 11$ & $\# 15$ & $\# 31$ & $\# 66$ & $\# 74$ & $\# 3$ & $\# 9$ & $\# 14$ & $\# 16$ & \#26 & $\# 28$ & $\# 48$ & \#55 \\
\hline & & & & & & & & & 29.8 & 30.9 & 30.1 & 30.4 & 29.7 & 30.8 & 30.1 & 30.5 & 30.6 \\
\hline $\mathrm{SiO}_{2}(\mathrm{wt} \%)$ & 29.10 & 29.90 & 29.90 & 29.38 & 29.96 & 29.33 & 29.88 & 29.76 & 4 & 2 & 4 & 3 & 5 & 2 & 2 & 2 & 1 \\
\hline $\mathrm{Al}_{2} \mathrm{O}_{3}$ & 2.32 & 2.53 & 2.29 & 2.20 & 2.31 & 2.00 & 2.15 & 1.94 & 1.85 & 2.30 & 1.39 & 1.64 & 1.33 & 1.69 & 1.46 & 1.92 & 2.01 \\
\hline \multirow{2}{*}{$\mathrm{P}_{2} \mathrm{O}_{5}$} & 0.06 & 0.03 & 0.04 & 0.05 & 0.04 & 0.07 & 0.06 & 0.06 & 0.04 & 0.04 & 0.03 & 0.03 & 0.04 & 0.02 & 0.03 & 0.04 & 0.03 \\
\hline & & & & & & & & & 35.9 & 36.1 & 36.8 & 36.3 & 36.8 & 37.1 & 37.0 & 36.8 & 36.7 \\
\hline $\mathrm{TiO}_{2}$ & 33.88 & 34.77 & 35.28 & 34.45 & 35.44 & 35.49 & 35.25 & 35.91 & 1 & 8 & 5 & 7 & 6 & 1 & 7 & 3 & 8 \\
\hline $\mathrm{Fe}_{2} \mathrm{O}_{3}$ & 0.64 & 0.64 & 0.74 & 0.61 & 0.81 & 0.61 & 0.48 & 0.47 & 0.57 & 0.60 & 0.33 & 0.51 & 0.35 & 0.40 & 0.54 & 0.37 & 0.43 \\
\hline \multirow[t]{2}{*}{$\mathrm{MnO}$} & 0.02 & 0.04 & 0.04 & 0.03 & 0.08 & 0.06 & 0.03 & 0.06 & 0.08 & 0.08 & 0.06 & 0.06 & 0.08 & 0.05 & 0.07 & 0.06 & 0.07 \\
\hline & & & & & & & & & 26.9 & 27.9 & 28.0 & 27.4 & 27.9 & 28.4 & 27.9 & 28.4 & 28.3 \\
\hline $\mathrm{CaO}$ & 25.47 & 26.65 & 26.74 & 25.79 & 27.13 & 26.53 & 26.54 & 26.87 & 0 & 3 & 5 & 7 & 5 & 1 & 0 & 3 & 9 \\
\hline $\mathrm{Nb}_{2} \mathrm{O}_{5}$ & 1.09 & 0.24 & 0.35 & 0.85 & 0.29 & 0.35 & 0.56 & 0.66 & 0.43 & 0.20 & 0.31 & 0.37 & 0.37 & 0.13 & 0.29 & 0.25 & 0.13 \\
\hline $\mathrm{Y}_{2} \mathrm{O}_{3}$ & 1.96 & 1.73 & 1.66 & 2.15 & 1.18 & 1.32 & 1.31 & 1.31 & 1.50 & 0.04 & 0.08 & 0.76 & 0.22 & 0.02 & 0.11 & 0.16 & 0.07 \\
\hline $\mathrm{La}_{2} \mathrm{O}_{3}$ & bdl & bdl & bdl & bdl & bdl & bdl & bdl & bdl & bdl & bdl & bdl & bdl & bdl & bdl & bdl & bdl & bdl \\
\hline $\mathrm{Ce}_{2} \mathrm{O}_{3}$ & 0.28 & 0.25 & 0.25 & 0.29 & 0.16 & 0.29 & 0.36 & 0.29 & 0.19 & bdl & 0.06 & 0.11 & 0.14 & bdl & 0.11 & 0.08 & 0.06 \\
\hline $\mathrm{Pr}_{2} \mathrm{O}_{3}$ & bdl & bdl & bdl & bdl & bdl & bdl & bdl & bdl & bdl & bdl & bdl & bdl & bdl & bdl & bdl & bdl & bdl \\
\hline $\mathrm{Nd}_{2} \mathrm{O}_{3}$ & 0.49 & 0.38 & 0.41 & 0.51 & 0.19 & 0.41 & 0.66 & 0.33 & 0.23 & bdl & bdl & bdl & bdl & bdl & bdl & bdl & bdl \\
\hline $\mathrm{Sm}_{2} \mathrm{O}_{3}$ & 0.29 & 0.23 & 0.26 & 0.29 & bdl & 0.20 & 0.30 & bdl & bdl & bdl & bdl & bdl & bdl & bdl & bdl & bdl & bdl \\
\hline $\mathrm{Gd}_{2} \mathrm{O}_{3}$ & na & 0.36 & 0.54 & 0.40 & 0.23 & na & 0.36 & 0.37 & 0.26 & bdl & 0.19 & bdl & na & bdl & na & bdl & bdl \\
\hline $\mathrm{Dy}_{2} \mathrm{O}_{3}$ & na & 0.36 & 0.39 & 0.45 & 0.25 & na & 0.36 & 0.16 & 0.24 & bdl & 0.17 & 0.22 & na & bdl & na & bdl & bdl \\
\hline $\mathrm{Er}_{2} \mathrm{O}_{3}$ & na & 0.20 & 0.17 & 0.23 & 0.11 & na & 0.14 & 0.12 & 0.16 & bdl & 0.14 & bdl & na & bdl & na & bdl & bdl \\
\hline
\end{tabular}




\begin{tabular}{|c|c|c|c|c|c|c|c|c|c|c|c|c|c|c|c|c|c|}
\hline $\mathrm{Yb}_{2} \mathrm{O}_{3}$ & na & 0.13 & 0.10 & 0.14 & 0.12 & na & 0.07 & 0.11 & 0.14 & bdl & 0.14 & 0.09 & na & bdl & na & bdl & bdl \\
\hline \multirow{2}{*}{$\Sigma$ REE } & 1.06 & 1.92 & 2.13 & 2.29 & 1.06 & 0.90 & 2.24 & 1.38 & 1.23 & 0.00 & 0.70 & 0.42 & 0.14 & 0.00 & 0.11 & 0.08 & 0.06 \\
\hline & & & & & & & & & 0.01 & & & & & & & & \\
\hline \multirow{3}{*}{$\begin{array}{l}\mathrm{ZrO}_{2} \\
\mathrm{~F}\end{array}$} & 0.041 & 0.011 & 0.023 & 0.024 & 0.008 & 0.019 & 0.030 & bdl & 5 & bdl & bdl & bdl & bdl & bdl & bdl & bdl & bdl \\
\hline & 0.10 & 0.17 & 0.22 & 0.14 & 0.29 & 0.22 & 0.22 & 0.22 & 0.20 & 0.45 & 0.27 & 0.20 & 0.24 & 0.44 & 0.33 & 0.33 & 0.34 \\
\hline & & & & & & & & & 98.5 & 98.7 & 98.2 & 98.2 & 97.3 & 99.0 & 98.0 & 99.0 & 98.9 \\
\hline Total & 95.73 & 98.64 & 99.41 & 97.97 & 98.60 & 96.89 & 98.77 & 98.63 & 7 & 4 & 2 & 6 & 5 & 8 & 3 & 0 & 2 \\
\hline \multicolumn{18}{|c|}{ Formula (25 O) } \\
\hline & & & & & & & & & 1.00 & 1.02 & 1.01 & 1.01 & 1.00 & 1.02 & 1.00 & 1.01 & 1.01 \\
\hline \multirow[t]{2}{*}{$\mathrm{Si}$} & 1.006 & 1.008 & 1.003 & 1.002 & 1.006 & 1.001 & 1.007 & 1.000 & 3 & 6 & 0 & 6 & 4 & 1 & 9 & 1 & 4 \\
\hline & & & & & & & & & 0.00 & 0.00 & 0.00 & 0.00 & 0.00 & 0.00 & 0.00 & 0.00 & 0.00 \\
\hline \multirow[t]{2}{*}{$\mathrm{P}$} & 0.002 & 0.001 & 0.001 & 0.001 & 0.001 & 0.002 & 0.002 & 0.002 & 1 & 1 & 1 & 1 & 1 & 1 & 1 & 1 & 1 \\
\hline & & & & & & & & & 0.07 & 0.09 & 0.09 & 0.06 & 0.05 & 0.06 & 0.05 & 0.07 & 0.07 \\
\hline \multirow[t]{2}{*}{ Al } & 0.094 & 0.101 & 0.091 & 0.088 & 0.092 & 0.080 & 0.086 & 0.077 & 3 & 0 & 2 & 5 & 3 & 6 & 8 & 5 & 9 \\
\hline & & & & & & & & & 0.01 & 0.01 & 0.01 & 0.01 & 0.00 & 0.01 & 0.01 & 0.00 & 0.01 \\
\hline \multirow[t]{2}{*}{$\mathrm{Fe}$} & 0.017 & 0.016 & 0.019 & 0.016 & 0.021 & 0.016 & 0.012 & 0.012 & 5 & 5 & 6 & 3 & 9 & 0 & 4 & 9 & 1 \\
\hline & & & & & & & & & 0.90 & 0.90 & 0.89 & 0.91 & 0.93 & 0.92 & 0.93 & 0.91 & 0.91 \\
\hline \multirow[t]{2}{*}{$\mathrm{Ti}$} & 0.881 & 0.882 & 0.890 & 0.884 & 0.895 & 0.911 & 0.894 & 0.908 & 9 & 3 & 5 & 3 & 6 & 5 & 5 & 8 & 7 \\
\hline & & & & & & & & & 0.00 & 0.00 & 0.00 & 0.00 & 0.00 & 0.00 & 0.00 & 0.00 & 0.00 \\
\hline \multirow[t]{2}{*}{$\mathrm{Nb}$} & 0.017 & 0.004 & 0.005 & 0.013 & 0.004 & 0.006 & 0.009 & 0.010 & 7 & 3 & 4 & 6 & 6 & 2 & 4 & 4 & 2 \\
\hline & & & & & & & & & 1.00 & 1.01 & 1.00 & 0.99 & 1.00 & 1.00 & 1.01 & 1.00 & 1.00 \\
\hline \multirow[t]{2}{*}{ sum } & 1.011 & 1.003 & 1.006 & 1.002 & 1.013 & 1.015 & 1.002 & 1.008 & 4 & 2 & 8 & 7 & 5 & 3 & 1 & 7 & 9 \\
\hline & & & & & & & & & 0.96 & 0.99 & 0.97 & 0.98 & 1.01 & 1.00 & 1.00 & 1.00 & 1.00 \\
\hline \multirow[t]{2}{*}{$\mathrm{Ca}$} & 0.943 & 0.962 & 0.961 & 0.942 & 0.976 & 0.970 & 0.959 & 0.968 & 9 & 2 & 6 & 3 & 1 & 8 & 2 & 9 & 8 \\
\hline & & & & & & & & & 0.00 & 0.00 & 0.00 & 0.00 & 0.00 & 0.00 & 0.00 & 0.00 & 0.00 \\
\hline \multirow[t]{2}{*}{$\mathrm{Mn}$} & 0.001 & 0.001 & 0.001 & 0.001 & 0.002 & 0.002 & 0.001 & 0.002 & 2 & 2 & 2 & 2 & 2 & 1 & 2 & 2 & 2 \\
\hline & & & & & & & & & 0.02 & 0.00 & 0.02 & 0.01 & 0.00 & 0.00 & 0.00 & 0.00 & 0.00 \\
\hline Y & 0.036 & 0.031 & 0.030 & 0.039 & 0.021 & 0.024 & 0.024 & 0.023 & 7 & 1 & 2 & 4 & 4 & 0 & 2 & 3 & 1 \\
\hline \multirow[t]{2}{*}{ La } & - & - & - & - & - & - & - & - & - & - & - & - & - & - & - & - & - \\
\hline & & & & & & & & & 0.00 & & 0.00 & 0.00 & 0.00 & & 0.00 & 0.00 & 0.00 \\
\hline \multirow[t]{2}{*}{$\mathrm{Ce}$} & 0.004 & 0.003 & 0.003 & 0.004 & 0.002 & 0.004 & 0.004 & 0.004 & 2 & - & 2 & 1 & 2 & - & 1 & 1 & 1 \\
\hline & & & & \multicolumn{11}{|c|}{55} & & & \\
\hline
\end{tabular}




\begin{tabular}{|c|c|c|c|c|c|c|c|c|c|c|c|c|c|c|c|c|c|}
\hline $\mathrm{Pr}$ & - & - & - & - & - & - & - & - & $\begin{array}{l}- \\
0.00\end{array}$ & - & - & - & - & - & - & - & - \\
\hline $\mathrm{Nd}$ & 0.006 & 0.005 & 0.005 & 0.006 & 0.002 & 0.005 & 0.008 & 0.004 & 3 & - & - & - & - & - & - & - & - \\
\hline Sm & 0.004 & 0.003 & 0.003 & 0.003 & - & 0.002 & 0.004 & - & $\begin{array}{l}- \\
0.00\end{array}$ & - & $\begin{array}{l}- \\
0.00\end{array}$ & - & - & - & - & - & - \\
\hline $\mathrm{Gd}$ & - & 0.004 & 0.006 & 0.005 & 0.003 & - & 0.004 & 0.004 & $\begin{array}{l}3 \\
0.00\end{array}$ & - & $\begin{array}{l}2 \\
0.00\end{array}$ & $\begin{array}{l}- \\
0.00\end{array}$ & - & - & - & - & - \\
\hline Dy & - & 0.004 & 0.004 & 0.005 & 0.003 & - & 0.004 & 0.002 & $\begin{array}{l}3 \\
0.00\end{array}$ & - & $\begin{array}{l}2 \\
0.00\end{array}$ & 2 & - & - & - & - & - \\
\hline $\mathrm{Er}$ & - & 0.002 & 0.002 & 0.002 & 0.001 & - & 0.002 & 0.001 & $\begin{array}{l}2 \\
0.00\end{array}$ & - & $\begin{array}{l}2 \\
0.00\end{array}$ & $\begin{array}{l}- \\
0.00\end{array}$ & - & - & - & - & - \\
\hline $\mathrm{Yb}$ & - & 0.001 & 0.001 & 0.001 & 0.001 & - & 0.001 & 0.001 & $\begin{array}{l}2 \\
1.01\end{array}$ & $\begin{array}{l}- \\
0.99\end{array}$ & $\begin{array}{l}1 \\
1.01\end{array}$ & $\begin{array}{l}1 \\
1.00\end{array}$ & $\begin{array}{l}- \\
1.02\end{array}$ & $\begin{array}{l}- \\
1.01\end{array}$ & $\begin{array}{l}- \\
1.00\end{array}$ & $\begin{array}{l}- \\
1.01\end{array}$ & $\begin{array}{l}- \\
1.01\end{array}$ \\
\hline sum & 0.994 & 1.017 & 1.017 & 1.010 & 1.013 & 1.008 & 1.011 & 1.012 & 5 & 8 & 3 & 8 & 0 & 2 & 8 & 7 & 4 \\
\hline $\mathrm{F}$ & 0.011 & 0.018 & 0.023 & 0.015 & 0.031 & 0.024 & 0.024 & 0.023 & $\begin{array}{l}0.02 \\
2\end{array}$ & $\begin{array}{l}0.04 \\
7\end{array}$ & $\begin{array}{l}0.02 \\
9\end{array}$ & $\begin{array}{l}0.02 \\
1\end{array}$ & $\begin{array}{l}0.02 \\
6\end{array}$ & $\begin{array}{l}0.04 \\
6\end{array}$ & $\begin{array}{l}0.03 \\
5\end{array}$ & $\begin{array}{l}0.03 \\
4\end{array}$ & $\begin{array}{l}0.03 \\
5\end{array}$ \\
\hline$(\mathrm{Ce} / \mathrm{Nd})_{\mathrm{N}}$ & 0.43 & 0.49 & 0.47 & 0.43 & 0.64 & 0.54 & 0.41 & 0.66 & 0.63 & - & - & - & - & - & - & - & - \\
\hline$(\mathrm{Y} / \mathrm{Nb})_{\mathrm{N}}$ & 0.32 & 1.25 & 0.84 & 0.45 & 0.71 & 0.66 & 0.41 & 0.35 & 0.62 & 0.03 & 0.04 & 0.37 & 0.11 & 0.02 & 0.07 & 0.11 & 0.09 \\
\hline $\mathrm{T}(\mathrm{Zr}$-in-Ttn $)\left({ }^{\circ} \mathrm{C}\right){ }^{\left({ }^{*}\right)}$ & 691 & 628 & 663 & 665 & 615 & 653 & 675 & - & 642 & - & - & - & - & - & - & - & - \\
\hline
\end{tabular}

$\left(^{*}\right)$ calculated at $0.2 \mathrm{GPa}$ with a fixed $\mathrm{TiO}_{2}$ activity of 0.7 by using the $\mathrm{Zr}$-in-Titanite thermobarometry (Hayden et al., 2008)

na: not analyzed; bld: below detection limit 
Table 3 - U-Th-Pb data on Titanite

\begin{tabular}{|c|c|c|c|c|c|c|c|c|c|c|c|c|c|c|c|c|c|}
\hline Spot & Sample & Grain & $\begin{array}{l}{ }^{207} \mathrm{~Pb}^{\mathrm{a}} \\
\text { (cps) }\end{array}$ & $\begin{array}{l}\mathrm{U}^{\mathrm{b}} \\
(\mathrm{ppm})\end{array}$ & $\begin{array}{l}\mathrm{Pb}^{\mathrm{b}} \\
(\mathrm{ppm})\end{array}$ & $\frac{T h^{b}}{U}$ & $\frac{{ }^{206} \mathrm{~Pb}^{\mathrm{c}}}{{ }^{238} \mathrm{U}}$ & $\begin{array}{l} \pm 2 \sigma \\
(\%)\end{array}$ & $\frac{{ }^{207} \mathrm{~Pb}^{\mathrm{c}}}{{ }^{235} \mathrm{U}}$ & $\begin{array}{l} \pm 2 \sigma \\
(\%)\end{array}$ & $\frac{{ }^{207} \mathrm{~Pb}^{\mathrm{c}}}{{ }^{206} \mathrm{~Pb}}$ & $\begin{array}{l} \pm 2 \sigma \\
(\%)\end{array}$ & rho $^{d}$ & $\frac{{ }^{206} \mathrm{~Pb}}{{ }^{238} \mathrm{U}}$ & $\begin{array}{l} \pm 2 \sigma \\
(\mathrm{Ma})\end{array}$ & $\frac{{ }^{206} \mathrm{~Pb}^{*}}{{ }^{238} \mathrm{U}}$ & $\begin{array}{l} \pm 2 \sigma \\
(\mathrm{Ma})\end{array}$ \\
\hline A06 & T14-09 & tit1 & 19401 & 209 & 15 & 0.95 & 0.02231 & 4.2 & 2.342 & 4.4 & 0.7616 & 1.3 & 0.95 & 142 & 6 & 17.6 & 1.3 \\
\hline $\mathrm{A} 07$ & T14-09 & tit1 & 24420 & 168 & 13 & 0.67 & 0.02533 & 6.7 & 2.702 & 6.8 & 0.7738 & 1.3 & 0.98 & 161 & 11 & 14.2 & 1.3 \\
\hline A08 & T14-09 & tit1 & 31233 & 134 & 47 & 0.71 & 0.1617 & 5.0 & 18.5 & 5.8 & 0.8300 & 2.9 & 0.87 & 966 & 45 & 14.5 & 0.9 \\
\hline A09 & T14-09 & tit1 & 7011 & 157 & 5 & 0.75 & 0.01086 & 4.4 & 1.021 & 4.8 & 0.682 & 2.1 & 0.90 & 70 & 3 & 14.0 & 0.9 \\
\hline A10 & T14-09 & tit1 & 11744 & 155 & 10 & 0.76 & 0.0209 & 6.0 & 2.117 & 6.3 & 0.7349 & 2 & 0.95 & 133 & 8 & 16.1 & 1.3 \\
\hline A11 & T14-09 & tit1 & 18499 & 226 & 15 & 0.60 & 0.02288 & 4.2 & 2.35 & 4.5 & 0.7450 & 1.7 & 0.93 & 146 & 6 & 16.6 & 1.3 \\
\hline $\mathrm{A} 12$ & T14-09 & tit1 & 8643 & 151 & 7 & 0.84 & 0.01399 & 5.2 & 1.335 & 5.6 & 0.6924 & 1.9 & 0.94 & 90 & 5 & 18.4 & 1.0 \\
\hline A13 & T14-09 & tit1 & 37458 & 243 & 29 & 0.52 & 0.03537 & 9.6 & 3.767 & 9.6 & 0.7727 & 1.1 & 0.99 & 224 & 21 & 16.5 & 1.1 \\
\hline A14 & T14-09 & tit1 & 17878 & 163 & 13 & 0.75 & 0.02211 & 5.2 & 2.316 & 5.5 & 0.7598 & 1.7 & 0.95 & 141 & 7 & 17.3 & 1.2 \\
\hline A15 & T14-09 & tit1 & 9433 & 191 & 8 & 0.67 & 0.01468 & 4.1 & 1.427 & 4.5 & 0.7052 & 1.9 & 0.91 & 94 & 4 & 15.6 & 1.2 \\
\hline A16 & T14-09 & tit1 & 21676 & 145 & 20 & 0.86 & 0.05797 & 5.3 & 6.332 & 6.4 & 0.7925 & 3.6 & 0.83 & 363 & 19 & 16.7 & 1.3 \\
\hline A38 & T14-09 & tit3 & 13243 & 243 & 9 & 0.66 & 0.01151 & 4.9 & 1.043 & 5.2 & 0.6578 & 1.8 & 0.94 & 74 & 4 & 18.0 & 1.0 \\
\hline A39 & T14-09 & tit3 & 11469 & 286 & 10 & 0.46 & 0.01265 & 3.9 & 1.173 & 4.2 & 0.6725 & 1.7 & 0.91 & 81 & 3 & 17.8 & 1.0 \\
\hline A40 & T14-09 & tit3 & 43576 & 315 & 33 & 0.47 & 0.02963 & 12.2 & 3.134 & 12.2 & 0.7673 & 1.2 & 0.99 & 188 & 23 & 16.1 & 1.2 \\
\hline A41 & T14-09 & tit3 & 32183 & 288 & 23 & 0.49 & 0.02293 & 12.6 & 2.382 & 12.7 & 0.7536 & 1.8 & 0.99 & 146 & 18 & 15.5 & 1.0 \\
\hline A42 & T14-09 & tit3 & 22320 & 156 & 16 & 0.86 & 0.04006 & 14.8 & 4.273 & 14.9 & 0.7739 & 1.7 & 0.99 & 253 & 37 & 18.1 & 1.2 \\
\hline A44 & T14-09 & tit3 & 19655 & 171 & 16 & 0.69 & 0.03145 & 4.9 & 3.303 & 5.1 & 0.7620 & 1.5 & 0.96 & 200 & 10 & 16.1 & 1.2 \\
\hline A45 & T14-09 & tit4 & 56068 & 184 & 39 & 0.39 & 0.05819 & 6.3 & 6.456 & 6.4 & 0.8049 & 0.91 & 0.99 & 365 & 23 & 16.8 & 1.3 \\
\hline A46 & T14-09 & tit4 & 82888 & 68 & 53 & 0.49 & 0.3058 & 3.8 & 35.37 & 3.9 & 0.8390 & 0.97 & 0.97 & 1720 & 57 & 18.1 & 1.7 \\
\hline A48 & T14-09 & tit4 & 20416 & 347 & 14 & 0.74 & 0.01213 & 5.4 & 1.157 & 5.7 & 0.6920 & 2 & 0.94 & 78 & 4 & 16.5 & 0.9 \\
\hline A49 & T14-09 & tit4 & 17464 & 281 & 14 & 0.58 & 0.01636 & 6.1 & 1.607 & 6.5 & 0.7127 & 2.2 & 0.94 & 105 & 6 & 16.5 & 0.9 \\
\hline A50 & T14-09 & tit5 & 27502 & 242 & 21 & 0.57 & 0.02859 & 10.3 & 2.99 & 10.5 & 0.7585 & 1.5 & 0.99 & 182 & 19 & 17.5 & 1.6 \\
\hline A51 & T14-09 & tit5 & 12537 & 277 & 9 & 0.54 & 0.0111 & 5.1 & 1.013 & 5.4 & 0.662 & 1.6 & 0.96 & 71 & 4 & 17.3 & 0.9 \\
\hline A52 & T14-09 & tit5 & 61613 & 309 & 41 & 0.56 & 0.03465 & 11.0 & 3.737 & 11.0 & 0.7825 & 0.84 & 1.00 & 220 & 24 & 16.7 & 1.4 \\
\hline A53 & T14-09 & tit5 & 14647 & 311 & 10 & 0.54 & 0.00972 & 3.9 & 0.8611 & 4.3 & 0.6430 & 1.7 & 0.92 & 62 & 2 & 13.5 & 0.8 \\
\hline A54 & T14-09 & tit6 & 92575 & 309 & 33 & 0.47 & 0.00796 & 8.3 & 0.6624 & 8.4 & 0.6038 & 0.92 & 0.99 & 51 & 4 & 14.4 & 1.0 \\
\hline A82 & T14-09 & tit9 & 26234 & 75 & 17 & 0.66 & 0.05301 & 5.8 & 5.907 & 5.9 & 0.8085 & 1.2 & 0.98 & 333 & 19 & 14.3 & 3.6 \\
\hline A83 & T14-09 & tit9 & 19282 & 124 & 14 & 0.87 & 0.03476 & 6.0 & 3.788 & 6.2 & 0.7906 & 1.5 & 0.97 & 220 & 13 & 15.9 & 1.2 \\
\hline
\end{tabular}




\begin{tabular}{|c|c|c|c|c|c|c|c|c|c|c|c|c|c|c|c|c|c|}
\hline A84 & T14-09 & tit9 & 10677 & 154 & 8 & 0.68 & 0.01592 & 4.2 & 1.603 & 4.6 & 0.7306 & 1.7 & 0.93 & 102 & 4 & 17.2 & 0.9 \\
\hline A85 & T14-09 & tit9 & 55231 & 127 & 46 & 0.74 & 0.1428 & 5.0 & 16.31 & 5.1 & 0.829 & 1.1 & 0.98 & 860 & 40 & 16.6 & 3.4 \\
\hline A86 & T14-09 & tit9 & 10683 & 124 & 8 & 0.75 & 0.01932 & 3.9 & 2.011 & 4.2 & 0.7551 & 1.6 & 0.92 & 123 & 5 & 17.3 & 1.7 \\
\hline A87 & T14-09 & tit9 & 10434 & 154 & 8 & 0.78 & 0.01692 & 4.8 & 1.702 & 5.2 & 0.7298 & 2 & 0.92 & 108 & 5 & 16.4 & 0.9 \\
\hline A88 & T14-09 & tit9 & 25517 & 127 & 19 & 0.62 & 0.04634 & 5.5 & 5.117 & 5.7 & 0.8011 & 1.3 & 0.97 & 292 & 16 & 17.4 & 1.3 \\
\hline A89 & T14-09 & tit9 & 20330 & 120 & 13 & 0.68 & 0.02536 & 13.0 & 2.692 & 13.1 & 0.7701 & 1.9 & 0.99 & 161 & 21 & 16.5 & 1.2 \\
\hline A90 & T14-09 & tit9 & 30433 & 66 & 20 & 0.66 & 0.07779 & 5.5 & 8.703 & 5.6 & 0.8117 & 1.1 & 0.98 & 483 & 26 & 14.7 & 1.0 \\
\hline A091 & T14-09 & tit9 & 23770 & 129 & 20 & 0.74 & 0.05208 & 3.9 & 5.68 & 4.1 & 0.7912 & 1.5 & 0.94 & 327 & 12 & 14.0 & 1.0 \\
\hline A92 & T14-09 & tit9 & 55053 & 41 & 34 & 0.56 & 0.2129 & 4.5 & 24.19 & 4.6 & 0.8241 & 0.79 & 0.99 & 1244 & 52 & 15.1 & 1.0 \\
\hline A93 & T14-09 & tit10 & 13371 & 165 & 11 & 0.95 & 0.02144 & 3.9 & 2.176 & 4.3 & 0.7364 & 1.8 & 0.91 & 137 & 5 & 17.0 & 1.3 \\
\hline A94 & T14-09 & tit10 & 137145 & 143 & 97 & 0.70 & 0.1923 & 9.5 & 21.93 & 9.5 & 0.8277 & 0.72 & 1.00 & 1134 & 99 & 15.9 & 1.1 \\
\hline A95 & T14-09 & tit10 & 5732 & 151 & 5 & 0.73 & 0.01128 & 4.0 & 1.031 & 4.7 & 0.6628 & 2.4 & 0.86 & 72 & 3 & 16.4 & 0.9 \\
\hline A97 & T14-09 & tit10 & 17473 & 149 & 13 & 0.75 & 0.03063 & 4.6 & 3.241 & 5.0 & 0.7676 & 1.9 & 0.93 & 194 & 9 & 17.4 & 1.1 \\
\hline A98 & T14-09 & tit10 & 23432 & 174 & 11 & 0.83 & 0.02016 & 13.1 & 2.073 & 13.3 & 0.7459 & 2 & 0.99 & 129 & 17 & 17.2 & 1.1 \\
\hline A99 & T14-09 & tit11 & 20040 & 74 & 19 & 0.34 & 0.0935 & 3.7 & 10.54 & 3.9 & 0.8176 & 1.3 & 0.95 & 576 & 21 & 13.8 & 1.0 \\
\hline A100 & T14-09 & tit11 & 98642 & 200 & 71 & 0.14 & 0.1003 & 4.6 & 11.36 & 4.7 & 0.8213 & 0.72 & 0.99 & 616 & 27 & 12.9 & 0.9 \\
\hline A101 & T14-09 & tit11 & 51921 & 265 & 43 & 0.57 & 0.05445 & 5.8 & 5.982 & 5.9 & 0.7969 & 1 & 0.98 & 342 & 19 & 16.6 & 1.2 \\
\hline A107 & T14-09 & tit11 & 9826 & 132 & 9 & 0.76 & 0.02428 & 4.9 & 2.48 & 5.4 & 0.741 & 2.3 & 0.90 & 155 & 8 & 17.3 & 1.7 \\
\hline A108 & T14-09 & tit11 & 31880 & 141 & 25 & 0.75 & 0.0557 & 12.8 & 6.13 & 12.8 & 0.7984 & 1.4 & 0.99 & 349 & 44 & 16.5 & 1.0 \\
\hline A109 & T14-09 & tit11 & 26588 & 88 & 22 & 0.98 & 0.08703 & 9.4 & 9.72 & 9.5 & 0.8103 & 1.4 & 0.99 & 538 & 49 & 17.6 & 1.4 \\
\hline A110 & T14-09 & tit11 & 28326 & 147 & 24 & 1.03 & 0.05103 & 5.1 & 5.535 & 5.3 & 0.7869 & 1.4 & 0.96 & 321 & 16 & 17.5 & 1.5 \\
\hline A111 & T14-09 & tit12 & 63023 & 147 & 48 & 0.70 & 0.1023 & 4.7 & 11.48 & 4.8 & 0.814 & 0.99 & 0.98 & 628 & 28 & 15.4 & 1.4 \\
\hline A112 & T14-09 & tit12 & 155272 & 43 & 121 & 0.54 & 0.8794 & 4.6 & 101.8 & 4.6 & 0.8397 & 0.62 & 0.99 & 4067 & 140 & 15.2 & 0.8 \\
\hline A113 & T14-09 & tit12 & 58377 & 127 & 44 & 0.65 & 0.103 & 4.1 & 11.68 & 4.2 & 0.8225 & 0.85 & 0.98 & 632 & 25 & 14.4 & 1.0 \\
\hline A114 & T14-09 & tit12 & 60732 & 160 & 33 & 0.95 & 0.03312 & 27.5 & 3.488 & 27.5 & 0.7640 & 0.98 & 1.00 & 210 & 57 & 17.3 & 1.7 \\
\hline A115 & T14-09 & tit12 & 12272 & 281 & 27 & 51.20 & 0.01867 & 3.9 & 1.87 & 4.2 & 0.7264 & 1.5 & 0.93 & 119 & 5 & 18.3 & 0.6 \\
\hline A126 & T14-09 & tit12 & 14101 & 339 & 12 & 0.69 & 0.01233 & 3.9 & 1.127 & 4.1 & 0.6631 & 1.4 & 0.94 & 79 & 3 & 16.8 & 0.7 \\
\hline A127 & T14-06 & tit12 & 68670 & 277 & 48 & 0.51 & 0.04776 & 4.1 & 5.278 & 4.2 & 0.8017 & 0.81 & 0.98 & 301 & 12 & 17.4 & 0.9 \\
\hline A128 & $\mathrm{T} 14-06$ & tit1 & 15904 & 269 & 13 & 0.51 & 0.01591 & 5.0 & 1.556 & 5.3 & 0.7094 & 1.6 & 0.95 & 102 & 5 & 16.7 & 0.6 \\
\hline A129 & T14-06 & tit1 & 43820 & 263 & 29 & 0.55 & 0.02867 & 16.8 & 3.107 & 16.9 & 0.7861 & 1.1 & 1.00 & 182 & 30 & 14.3 & 0.8 \\
\hline A130 & T14-06 & tit1 & 58504 & 189 & 44 & 0.63 & 0.0683 & 4.7 & 7.705 & 4.8 & 0.8184 & 0.99 & 0.98 & 426 & 19 & 14.1 & 0.8 \\
\hline A131 & T14-06 & tit1 & 19439 & 329 & 18 & 0.85 & 0.02005 & 4.0 & 1.998 & 4.2 & 0.723 & 1.4 & 0.94 & 128 & 5 & 16.3 & 0.5 \\
\hline A132 & T14-06 & tit1 & 21541 & 470 & 16 & 0.61 & 0.01058 & 4.2 & 0.9717 & 4.4 & 0.666 & 1.3 & 0.96 & 68 & 3 & 15.0 & 0.6 \\
\hline
\end{tabular}




\begin{tabular}{|c|c|c|c|c|c|c|c|c|c|c|c|c|c|c|c|c|}
\hline A133 & T14-06 & tit1 & 29981 & 338 & 22 & 0.59 & 0.01943 & 4.5 & 1.992 & 4.6 & 0.7439 & 1.1 & 0.97 & 124 & 6 & 14.9 \\
\hline A134 & T14-06 & tit1 & 12937 & 396 & 9 & 0.66 & 0.0069 & 3.9 & 0.5447 & 4.2 & 0.573 & 1.5 & 0.93 & 44 & 2 & 15.6 \\
\hline A135 & T14-06 & tit1 & 27306 & 340 & 19 & 0.69 & 0.016 & 12.0 & 1.619 & 12.0 & 0.7339 & 1.2 & 0.99 & 102 & 12 & 15.2 \\
\hline A136 & T14-06 & tit1 & 22969 & 250 & 18 & 0.59 & 0.02188 & 5.4 & 2.285 & 5.5 & 0.7576 & 1.1 & 0.98 & 140 & 7 & 14.9 \\
\hline A137 & T14-06 & tit1 & 25465 & 201 & 22 & 0.56 & 0.03899 & 4.2 & 4.133 & 4.4 & 0.7689 & 1.3 & 0.96 & 247 & 10 & 15.4 \\
\hline A138 & T14-06 & tit1 & 16008 & 208 & 13 & 0.69 & 0.02078 & 4.0 & 2.096 & 4.1 & 0.7318 & 1.3 & 0.95 & 133 & 5 & 15.5 \\
\hline A139 & T14-06 & tit1 & 10892 & 237 & 9 & 0.76 & 0.01397 & 4.2 & 1.31 & 4.4 & 0.6802 & 1.5 & 0.94 & 89 & 4 & 16.4 \\
\hline A140 & T14-06 & tit1 & 27485 & 189 & 18 & 0.78 & 0.02412 & 4.9 & 2.527 & 5.1 & 0.76 & 1.4 & 0.96 & 154 & 7 & 15.7 \\
\hline A141 & T14-06 & tit1 & 27828 & 180 & 18 & 0.47 & 0.0247 & 4.0 & 2.605 & 4.1 & 0.765 & 1.1 & 0.97 & 157 & 6 & 15.3 \\
\hline A142 & T14-06 & tit2 & 44244 & 341 & 33 & 0.64 & 0.02867 & 9.9 & 3.088 & 10.0 & 0.7813 & 1.2 & 0.99 & 182 & 18 & 14.9 \\
\hline A143 & T14-06 & tit2 & 16091 & 489 & 12 & 0.68 & 0.00824 & 3.9 & 0.7078 & 4.1 & 0.6231 & 1.4 & 0.94 & 53 & 2 & 15.8 \\
\hline A144 & T14-06 & tit2 & 14801 & 440 & 12 & 0.56 & 0.0102 & 4.7 & 0.9019 & 5.0 & 0.6415 & 1.7 & 0.94 & 65 & 3 & 15.7 \\
\hline A145 & T14-06 & tit2 & 34201 & 227 & 25 & 0.54 & 0.03785 & 4.8 & 4.043 & 4.9 & 0.7749 & 1.2 & 0.97 & 239 & 11 & 15.5 \\
\hline A151 & T14-06 & tit2 & 26289 & 643 & 18 & 0.60 & 0.00795 & 3.8 & 0.6688 & 4.0 & 0.61 & 1.3 & 0.95 & 51 & 2 & 14.9 \\
\hline A152 & T14-06 & tit2 & 20114 & 308 & 14 & 0.60 & 0.01448 & 6.1 & 1.404 & 6.4 & 0.7037 & 2.2 & 0.94 & 93 & 6 & 14.3 \\
\hline A154 & T14-06 & tit2 & 43067 & 580 & 32 & 0.57 & 0.01881 & 4.1 & 1.878 & 4.3 & 0.7245 & 1.3 & 0.96 & 120 & 5 & 15.4 \\
\hline A155 & T14-06 & tit2 & 34610 & 732 & 26 & 0.68 & 0.01076 & 4.8 & 0.9899 & 4.9 & 0.6672 & 0.99 & 0.98 & 69 & 3 & 15.0 \\
\hline A156 & T14-06 & tit2 & 17277 & 695 & 14 & 0.67 & 0.00728 & 3.8 & 0.5839 & 4.0 & 0.5823 & 1.4 & 0.94 & 47 & 2 & 14.8 \\
\hline A157 & T14-06 & tit2 & 20089 & 391 & 16 & 0.58 & 0.01386 & 3.8 & 1.322 & 4.0 & 0.6922 & 1.2 & 0.95 & 89 & 3 & 14.1 \\
\hline A158 & T14-06 & tit2 & 38004 & 830 & 30 & 0.67 & 0.01216 & 3.9 & 1.151 & 4.0 & 0.6866 & 0.99 & 0.97 & 78 & 3 & 15.9 \\
\hline A159 & T14-06 & tit2 & 19227 & 316 & 14 & 0.57 & 0.01346 & 4.2 & 1.309 & 4.6 & 0.7059 & 1.7 & 0.93 & 86 & 4 & 16.1 \\
\hline A160 & T14-06 & tit2 & 27355 & 285 & 20 & 0.45 & 0.0219 & 4.3 & 2.288 & 4.5 & 0.7581 & 1.1 & 0.97 & 140 & 6 & 14.0 \\
\hline A161 & T14-06 & tit2 & 37324 & 413 & 29 & 0.56 & 0.02281 & 4.1 & 2.365 & 4.2 & 0.7522 & 0.9 & 0.98 & 145 & 6 & 14.9 \\
\hline A162 & T14-06 & tit2 & 48886 & 266 & 38 & 0.73 & 0.04344 & 4.2 & 4.747 & 4.3 & 0.7927 & 0.86 & 0.98 & 274 & 11 & 15.9 \\
\hline A163 & T14-06 & tit2 & 60165 & 192 & 44 & 0.73 & 0.06457 & 4.2 & 7.254 & 4.3 & 0.815 & 0.8 & 0.98 & 403 & 17 & 17.4 \\
\hline A164 & T14-06 & tit2 & 58109 & 148 & 33 & 0.96 & 0.04618 & 4.5 & 5.172 & 4.6 & 0.8125 & 0.85 & 0.98 & 291 & 13 & 16.0 \\
\hline A165 & T14-06 & tit2 & 34299 & 152 & 27 & 0.31 & 0.05148 & 3.8 & 5.681 & 4.0 & 0.8005 & 1.2 & 0.96 & 324 & 12 & 14.1 \\
\hline A166 & T14-06 & tit2 & 68667 & 111 & 48 & 0.25 & 0.1151 & 4.2 & 13.08 & 4.2 & 0.8246 & 0.74 & 0.98 & 702 & 28 & 13.7 \\
\hline A167 & T14-06 & tit2 & 45058 & 114 & 33 & 0.33 & 0.07853 & 7.6 & 8.853 & 7.7 & 0.8178 & 0.88 & 0.99 & 487 & 36 & 14.4 \\
\hline A168 & T14-06 & tit2 & 135009 & 37 & 88 & 0.39 & 0.7667 & 4.3 & 88.89 & 4.3 & 0.8411 & 0.65 & 0.99 & 3669 & 121 & 15.0 \\
\hline A169 & T14-06 & tit2 & 32518 & 5 & 13 & 0.67 & 1.012 & 9.1 & 117 & 9.2 & 0.8394 & 0.92 & 1.00 & 4506 & 304 & 15.4 \\
\hline A170 & T14-06 & tit2 & 54658 & 29 & 38 & 0.33 & 0.3512 & 4.0 & 41.07 & 4.2 & 0.8484 & 1 & 0.97 & 1940 & 68 & 14.8 \\
\hline A171 & T14-06 & tit2 & 24454 & 285 & 15 & 0.50 & 0.0185 & 5.4 & 1.869 & 5.8 & 0.7331 & 2.2 & 0.92 & 118 & 6 & 15.2 \\
\hline
\end{tabular}




\begin{tabular}{|c|c|c|c|c|c|c|c|c|c|c|c|c|c|c|c|c|}
\hline A173 & T14-06 & tit2 & 36901 & 125 & 27 & 0.30 & 0.06035 & 4.4 & 6.759 & 4.5 & 0.8126 & 0.95 & 0.98 & 378 & 16 & 16.5 \\
\hline A174 & T14-06 & tit2 & 54923 & 415 & 43 & 0.66 & 0.03386 & 5.0 & 3.586 & 5.1 & 0.7685 & 0.97 & 0.98 & 215 & 11 & 16.3 \\
\hline A175 & T14-06 & tit2 & 60835 & 297 & 41 & 0.69 & 0.03588 & 5.9 & 3.926 & 5.9 & 0.794 & 0.79 & 0.99 & 227 & 13 & 17.8 \\
\hline A179 & T14-06 & tit2 & 5146 & 1367 & 14 & 0.58 & 0.00502 & 6.3 & 0.2984 & 9.5 & 0.431 & 7.1 & 0.66 & 32 & 2 & 15.7 \\
\hline A189 & T14-06 & tit3 & 13397 & 252 & 10 & 0.71 & 0.01248 & 3.8 & 1.214 & 4.1 & 0.7062 & 1.5 & 0.93 & 80 & 3 & 17.8 \\
\hline A190 & T14-06 & tit3 & 17445 & 287 & 13 & 0.57 & 0.01328 & 3.9 & 1.316 & 4.1 & 0.7191 & 1.3 & 0.95 & 85 & 3 & 17.1 \\
\hline A191 & T14-06 & tit3 & 44863 & 296 & 36 & 0.64 & 0.03856 & 4.1 & 4.2 & 4.2 & 0.7902 & 1.1 & 0.97 & 244 & 10 & 17.5 \\
\hline A192 & T14-06 & tit3 & 53585 & 345 & 38 & 0.72 & 0.03068 & 3.9 & 3.345 & 4.0 & 0.7909 & 0.84 & 0.98 & 195 & 8 & 16.1 \\
\hline A193 & T14-06 & tit3 & 20380 & 303 & 15 & 0.61 & 0.01493 & 5.0 & 1.485 & 5.2 & 0.7214 & 1.4 & 0.96 & 96 & 5 & 14.0 \\
\hline A199 & T14-06 & tit3 & 17725 & 386 & 14 & 0.62 & 0.01114 & 4.6 & 1.047 & 4.8 & 0.6824 & 1.5 & 0.95 & 71 & 3 & 17.2 \\
\hline A200 & T14-06 & tit3 & 74898 & 241 & 54 & 0.70 & 0.0644 & 5.0 & 7.185 & 5.1 & 0.8095 & 0.74 & 0.99 & 402 & 20 & 15.2 \\
\hline A201 & T14-06 & tit3 & 17635 & 360 & 13 & 0.75 & 0.01182 & 4.0 & 1.128 & 4.3 & 0.6927 & 1.6 & 0.93 & 76 & 3 & 18.1 \\
\hline A202 & T14-06 & tit3 & 38690 & 252 & 27 & 0.57 & 0.03155 & 5.2 & 3.414 & 5.3 & 0.7851 & 0.99 & 0.98 & 200 & 10 & 16.5 \\
\hline A203 & T14-06 & tit3 & 22073 & 312 & 14 & 0.54 & 0.01398 & 4.4 & 1.374 & 4.5 & 0.7126 & 1.2 & 0.97 & 90 & 4 & 15.5 \\
\hline A204 & T14-06 & tit3 & 46913 & 240 & 36 & 0.49 & 0.04425 & 4.1 & 4.866 & 4.2 & 0.7978 & 0.85 & 0.98 & 279 & 11 & 16.0 \\
\hline A205 & T14-06 & tit3 & 67324 & 135 & 47 & 0.56 & 0.09455 & 3.8 & 10.71 & 3.8 & 0.8216 & 0.77 & 0.98 & 582 & 21 & 14.5 \\
\hline A206 & T14-06 & tit3 & 124537 & 185 & 92 & 0.49 & 0.1408 & 3.8 & 16.1 & 3.9 & 0.8294 & 0.68 & 0.98 & 849 & 30 & 13.7 \\
\hline A207 & T14-06 & tit3 & 49659 & 185 & 38 & 0.50 & 0.06056 & 3.8 & 6.706 & 3.9 & 0.8033 & 0.97 & 0.97 & 379 & 14 & 15.2 \\
\hline A208 & T14-06 & tit3 & 29014 & 28 & 16 & 0.59 & 0.1008 & 6.0 & 11.49 & 6.2 & 0.8271 & 1.4 & 0.97 & 619 & 36 & 16.0 \\
\hline A209 & T14-06 & tit3 & 25171 & 130 & 19 & 0.66 & 0.05006 & 3.9 & 5.502 & 4.1 & 0.7975 & 1.4 & 0.94 & 315 & 12 & 15.9 \\
\hline A210 & T14-06 & tit3 & 27640 & 58 & 21 & 0.57 & 0.1041 & 4.5 & 11.79 & 4.7 & 0.8215 & 1.2 & 0.97 & 639 & 28 & 15.6 \\
\hline A211 & T14-06 & tit3 & 30352 & 35 & 18 & 0.57 & 0.1092 & 4.3 & 12.32 & 4.4 & 0.8189 & 1.1 & 0.97 & 668 & 27 & 16.5 \\
\hline A212 & T14-06 & tit3 & 33938 & 34 & 17 & 0.66 & 0.06259 & 17.6 & 7.008 & 17.7 & 0.8124 & 1.2 & 1.00 & 391 & 67 & 14.0 \\
\hline A213 & T14-06 & tit3 & 28904 & 484 & 22 & 0.64 & 0.01359 & 4.1 & 1.318 & 4.3 & 0.7036 & 1.2 & 0.96 & 87 & 4 & 14.3 \\
\hline $\mathrm{A} 214$ & T14-06 & tit3 & 19271 & 444 & 15 & 0.60 & 0.01032 & 4.5 & 0.9466 & 4.7 & 0.6651 & 1.3 & 0.96 & 66 & 3 & 14.0 \\
\hline A215 & T14-06 & tit3 & 12078 & 254 & 10 & 0.54 & 0.01233 & 3.8 & 1.157 & 4.1 & 0.6812 & 1.6 & 0.92 & 79 & 3 & 13.6 \\
\hline A216 & T14-06 & tit3 & 26922 & 237 & 20 & 0.71 & 0.02504 & 3.7 & 2.643 & 3.8 & 0.7657 & 0.84 & 0.98 & 159 & 6 & 13.8 \\
\hline A217 & T14-06 & tit3 & 43225 & 185 & 34 & 0.64 & 0.05635 & 3.7 & 6.297 & 3.8 & 0.8107 & 0.84 & 0.98 & 353 & 13 & 13.0 \\
\hline A218 & T14-06 & tit4 & 49270 & 577 & 36 & 0.21 & 0.01805 & 4.2 & 1.842 & 4.3 & 0.7403 & 0.93 & 0.98 & 115 & 5 & 16.7 \\
\hline A219 & T14-06 & tit4 & 34284 & 157 & 24 & 0.38 & 0.04043 & 4.2 & 4.49 & 4.4 & 0.8057 & 1.1 & 0.97 & 256 & 11 & 16.0 \\
\hline A220 & T14-06 & tit4 & 19928 & 333 & 16 & 0.32 & 0.01509 & 3.8 & 1.516 & 4.0 & 0.729 & 1.3 & 0.95 & 97 & 4 & 15.4 \\
\hline A221 & T14-06 & tit4 & 23268 & 534 & 18 & 0.38 & 0.01121 & 3.9 & 1.053 & 4.2 & 0.6813 & 1.6 & 0.92 & 72 & 3 & 15.3 \\
\hline A222 & T14-06 & tit4 & 29066 & 11 & 21 & 0.39 & 0.5193 & 4.6 & 60.3 & 4.8 & 0.8425 & 1.3 & 0.96 & 2696 & 103 & 13.7 \\
\hline
\end{tabular}




\begin{tabular}{|c|c|c|c|c|c|c|c|c|c|c|c|c|c|c|c|c|}
\hline A223 & T14-06 & tit5 & 46682 & 96 & 30 & 0.54 & 0.07689 & 4.3 & 8.692 & 4.4 & 0.8202 & 1 & 0.97 & 478 & 20 & 16.7 \\
\hline A224 & T14-06 & tit5 & 70350 & 112 & 79 & 0.43 & 0.2775 & 4.2 & 31.94 & 4.3 & 0.8351 & 0.86 & 0.98 & 1579 & 59 & 16.9 \\
\hline A225 & T14-06 & tit6 & 23212 & 208 & 19 & 0.73 & 0.0306 & 3.8 & 3.22 & 4.1 & 0.7634 & 1.5 & 0.93 & 194 & 7 & 17.4 \\
\hline A226 & $\mathrm{T} 14-06$ & tit6 & 17684 & 163 & 13 & 0.46 & 0.02377 & 4.6 & 2.481 & 4.9 & 0.7571 & 1.8 & 0.93 & 151 & 7 & 16.6 \\
\hline A227 & T14-06 & tit6 & 17167 & 354 & 14 & 0.61 & 0.01263 & 4.4 & 1.194 & 4.7 & 0.6859 & 1.7 & 0.93 & 81 & 4 & 15.9 \\
\hline A228 & T14-06 & tit6 & 34295 & 168 & 25 & 0.55 & 0.04075 & 3.9 & 4.416 & 4.0 & 0.7862 & 1.1 & 0.96 & 257 & 10 & 16.3 \\
\hline A229 & T14-06 & tit6 & 57649 & 271 & 43 & 0.59 & 0.04912 & 5.2 & 5.457 & 5.3 & 0.806 & 1.1 & 0.98 & 309 & 16 & 15.6 \\
\hline A230 & T14-06 & tit6 & 79983 & 378 & 60 & 0.37 & 0.04755 & 6.0 & 5.333 & 6.0 & 0.8138 & 0.77 & 0.99 & 299 & 18 & 16.3 \\
\hline A231 & T14-06 & tit6 & 98362 & 252 & 63 & 0.57 & 0.06813 & 5.4 & 7.611 & 5.6 & 0.8104 & 1.6 & 0.96 & 425 & 22 & 17.0 \\
\hline A232 & T14-06 & tit6 & 33009 & 276 & 27 & 0.60 & 0.03187 & 4.9 & 3.386 & 5.0 & 0.7706 & 1.1 & 0.97 & 202 & 10 & 17.1 \\
\hline A233 & T14-06 & tit6 & 84079 & 257 & 59 & 0.54 & 0.06307 & 6.9 & 7.117 & 6.9 & 0.8187 & 0.81 & 0.99 & 394 & 26 & 16.9 \\
\hline A234 & T14-06 & tit6 & 36541 & 168 & 24 & 0.47 & 0.04697 & 5.9 & 5.215 & 6.0 & 0.8055 & 1.2 & 0.98 & 296 & 17 & 15.8 \\
\hline A235 & T14-06 & tit6 & 45243 & 161 & 34 & 0.61 & 0.06255 & 5.6 & 6.977 & 5.7 & 0.8092 & 1.1 & 0.98 & 391 & 21 & 16.0 \\
\hline A237 & $\mathrm{T} 14-06$ & tit6 & 30408 & 215 & 24 & 0.61 & 0.03421 & 5.2 & 3.699 & 5.3 & 0.7846 & 1.2 & 0.98 & 217 & 11 & 17.0 \\
\hline A243 & T14-06 & tit6 & 14104 & 134 & 11 & 0.59 & 0.025 & 4.9 & 2.636 & 5.2 & 0.765 & 1.7 & 0.95 & 159 & 8 & 15.9 \\
\hline A244 & T14-06 & tit6 & 23443 & 301 & 20 & 0.69 & 0.02154 & 3.8 & 2.194 & 4.0 & 0.7389 & 1.2 & 0.95 & 137 & 5 & 17.3 \\
\hline A245 & T14-06 & tit6 & 24113 & 79 & 19 & 0.57 & 0.07213 & 4.9 & 8.033 & 5.0 & 0.8079 & 0.89 & 0.98 & 449 & 21 & 16.9 \\
\hline A246 & T14-06 & tit6 & 44901 & 297 & 35 & 0.73 & 0.03611 & 3.8 & 3.916 & 3.9 & 0.7867 & 0.99 & 0.97 & 229 & 9 & 15.4 \\
\hline A247 & T14-06 & tit6 & 14081 & 235 & 11 & 0.48 & 0.01433 & 4.3 & 1.421 & 4.6 & 0.7193 & 1.4 & 0.95 & 92 & 4 & 13.6 \\
\hline A248 & T14-06 & tit6 & 19990 & 150 & 15 & 0.50 & 0.03078 & 4.9 & 3.304 & 5.0 & 0.7787 & 1.3 & 0.97 & 195 & 9 & 16.3 \\
\hline A249 & T14-06 & tit7 & 13911 & 339 & 11 & 0.38 & 0.01117 & 3.8 & 1.017 & 4.2 & 0.66 & 1.6 & 0.92 & 72 & 3 & 15.7 \\
\hline A250 & T14-06 & tit7 & 35792 & 163 & 28 & 0.42 & 0.05047 & 4.0 & 5.567 & 4.2 & 0.8002 & 1.3 & 0.95 & 317 & 13 & 15.1 \\
\hline A251 & T14-06 & tit7 & 15100 & 144 & 11 & 0.47 & 0.02376 & 4.5 & 2.506 & 4.7 & 0.7651 & 1.2 & 0.97 & 151 & 7 & 16.3 \\
\hline A252 & $\mathrm{T} 14-06$ & tit7 & 22279 & 216 & 17 & 0.42 & 0.02322 & 3.9 & 2.441 & 4.1 & 0.7627 & 1.5 & 0.93 & 148 & 6 & 15.0 \\
\hline A253 & T14-06 & tit7 & 14813 & 132 & 11 & 0.46 & 0.02641 & 4.0 & 2.774 & 4.4 & 0.7618 & 1.9 & 0.90 & 168 & 7 & 11.2 \\
\hline A254 & T14-06 & tit7 & 33158 & 238 & 26 & 0.49 & 0.03411 & 3.9 & 3.651 & 4.0 & 0.7765 & 1 & 0.97 & 216 & 8 & 14.6 \\
\hline A255 & T14-06 & tit7 & 32605 & 153 & 25 & 0.48 & 0.04834 & 3.9 & 5.299 & 4.0 & 0.7951 & 1.1 & 0.96 & 304 & 11 & 14.9 \\
\hline A256 & T14-06 & tit7 & 34871 & 127 & 27 & 0.41 & 0.0642 & 3.9 & 7.259 & 4.0 & 0.8203 & 0.97 & 0.97 & 401 & 15 & 15.0 \\
\hline A257 & T14-06 & tit7 & 31523 & 127 & 25 & 0.43 & 0.0575 & 4.3 & 6.337 & 4.4 & 0.7995 & 1.2 & 0.96 & 360 & 15 & 13.6 \\
\hline A258 & T14-06 & tit7 & 66714 & 581 & 55 & 0.59 & 0.03018 & 4.1 & 3.235 & 4.2 & 0.7776 & 0.89 & 0.98 & 192 & 8 & 15.9 \\
\hline A259 & T14-06 & tit8 & 32122 & 338 & 26 & 0.61 & 0.02381 & 4.1 & 2.487 & 4.3 & 0.7577 & 1.1 & 0.96 & 152 & 6 & 16.6 \\
\hline A260 & T14-06 & tit8 & 14443 & 322 & 11 & 0.58 & 0.0114 & 3.7 & 1.043 & 4.2 & 0.6636 & 1.9 & 0.89 & 73 & 3 & 13.7 \\
\hline A261 & T14-06 & tit8 & 18858 & 210 & 14 & 1.17 & 0.02091 & 5.1 & 2.137 & 5.4 & 0.7413 & 1.8 & 0.94 & 133 & 7 & 17.2 \\
\hline
\end{tabular}




\begin{tabular}{|c|c|c|c|c|c|c|c|c|c|c|c|c|c|c|c|c|c|}
\hline A262 & T14-06 & tit8 & 9184 & 169 & 8 & 1.13 & 0.0150 & 3.8 & 1.438 & 4.2 & 0.6955 & 1.8 & 0.90 & 96 & 4 & 18.0 & 1.6 \\
\hline A263 & T14-06 & tit8 & 10491 & 189 & 8 & 1.22 & 0.01467 & 3.8 & 1.406 & 4.1 & 0.6952 & 1.5 & 0.93 & 94 & 4 & 16.9 & 1.1 \\
\hline A264 & T14-06 & tit8 & 13269 & 194 & 11 & 1.23 & 0.01891 & 3.8 & 1.914 & 4.1 & 0.7343 & 1.5 & 0.93 & 121 & 5 & 17.1 & 1.5 \\
\hline A265 & T14-06 & tit8 & 26146 & 167 & 20 & 0.73 & 0.03596 & 3.8 & 3.912 & 4.0 & 0.7893 & 1.3 & 0.94 & 228 & 9 & 14.8 & 0.9 \\
\hline A266 & T14-06 & tit8 & 11705 & 212 & 9 & 0.68 & 0.01221 & 4.4 & 1.159 & 4.8 & 0.6886 & 1.9 & 0.91 & 78 & 3 & 15.2 & 1.3 \\
\hline A267 & T14-06 & tit9 & 15776 & 102 & 12 & 0.61 & 0.03717 & 4.5 & 4.075 & 4.9 & 0.7953 & 1.8 & 0.93 & 235 & 10 & 15.9 & 1.0 \\
\hline A268 & T14-06 & tit9 & 31318 & 11 & 23 & 0.79 & 0.5438 & 4.1 & 62.25 & 4.3 & 0.8304 & 1.5 & 0.94 & 2799 & 93 & 17.1 & 1.5 \\
\hline A269 & T14-06 & tit9 & 22063 & 134 & 15 & 0.62 & 0.02904 & 6.2 & 3.115 & 6.4 & 0.7781 & 1.4 & 0.98 & 185 & 11 & 13.6 & 0.9 \\
\hline A270 & T14-06 & tit9 & 14606 & 165 & 11 & 0.59 & 0.01865 & 3.9 & 1.928 & 4.2 & 0.7499 & 1.7 & 0.92 & 119 & 5 & 15.6 & 1.2 \\
\hline A271 & T14-06 & tit9 & 17503 & 28 & 13 & 0.63 & 0.1239 & 4.5 & 13.94 & 4.7 & 0.8166 & 1.5 & 0.95 & 753 & 32 & 15.2 & 3.2 \\
\hline A272 & T14-06 & tit9 & 28085 & 101 & 19 & 0.63 & 0.05275 & 4.6 & 5.923 & 4.8 & 0.8146 & 1.4 & 0.96 & 331 & 15 & 14.3 & 1.4 \\
\hline A273 & T14-06 & tit9 & 20668 & 284 & 15 & 0.52 & 0.01514 & 4.5 & 1.5 & 4.7 & 0.7189 & 1.3 & 0.96 & 97 & 4 & 15.8 & 1.2 \\
\hline A274 & T14-06 & tit9 & 26225 & 295 & 22 & 0.55 & 0.0246 & 3.8 & 2.546 & 4.0 & 0.7509 & 1.1 & 0.96 & 157 & 6 & 16.4 & 1.2 \\
\hline A275 & T14-06 & tit9 & 19099 & 255 & 14 & 0.64 & 0.01564 & 5.2 & 1.573 & 5.4 & 0.7298 & 1.3 & 0.97 & 100 & 5 & 15.9 & 1.2 \\
\hline A276 & T14-06 & tit9 & 46722 & 183 & 37 & 0.49 & 0.06012 & 4.0 & 6.684 & 4.1 & 0.8065 & 0.83 & 0.98 & 376 & 15 & 15.4 & 3.8 \\
\hline A277 & T14-06 & tit9 & 14105 & 107 & 11 & 0.55 & 0.03001 & 4.2 & 3.244 & 4.6 & 0.7842 & 1.8 & 0.92 & 191 & 8 & 16.0 & 1.1 \\
\hline A278 & T14-06 & tit9 & 15091 & 92 & 12 & 0.69 & 0.03987 & 4.1 & 4.436 & 4.4 & 0.8071 & 1.4 & 0.95 & 252 & 10 & 15.9 & 1.6 \\
\hline A279 & T14-06 & tit9 & 36907 & 80 & 27 & 0.56 & 0.09369 & 4.6 & 10.57 & 4.8 & 0.8185 & 1.1 & 0.97 & 577 & 26 & 15.6 & 1.2 \\
\hline A280 & T14-06 & tit9 & 46371 & 4488 & 41 & 0.05 & 0.00413 & 4.3 & 0.2295 & 5.0 & 0.4029 & 2.6 & 0.86 & 27 & 1 & 14.3 & 0.6 \\
\hline A281 & T14-06 & tit9 & 46396 & 2232 & 35 & 0.09 & 0.00589 & 4.0 & 0.4263 & 5.9 & 0.5253 & 4.3 & 0.68 & 38 & 2 & 14.5 & 0.3 \\
\hline A289 & & & 71093 & 4 & 53 & 0.33 & 4.004 & 6.9 & 465.3 & 6.9 & 0.8429 & 0.87 & 0.99 & 10381 & 365 & - & - \\
\hline BB-16 ${ }^{\mathrm{e}}$ & & & 21812 & 453 & 40.8 & 0.30 & 0.09090 & 1.6 & 0.7358 & 1.9 & 0.05870 & 1.0 & 0.72 & & & 561 & 8 \\
\hline Tita $\mathrm{T} 1^{\mathrm{e}}$ & & & 28071 & 142 & 50 & 3.62 & 0.1667 & 2.4 & 1.6691 & 3.3 & 0.07260 & 1.9 & 0.61 & & & 994 & 22 \\
\hline BearL tita $^{e}$ & & & 21667 & 7 & 2 & 2.85 & 0.1781 & 1.8 & 1.8270 & 3.2 & 0.07441 & 3.4 & 0.41 & & & 1056 & 18 \\
\hline
\end{tabular}


${ }^{c}$ corrected for background, within-run $\mathrm{Pb} / \mathrm{U}$ fractionation (in case of ${ }^{206} \mathrm{~Pb} /{ }^{238} \mathrm{U}$ ) and subsequently normalised to GJ-1 (ID-TIMS value/measured value)

${ }^{207} \mathrm{~Pb} /{ }^{235} \mathrm{U}$ calculated using ${ }^{207} \mathrm{~Pb} /{ }^{206} \mathrm{~Pb} /\left({ }^{238} \mathrm{U} /{ }^{206} \mathrm{~Pb}{ }^{*} 1 / 137.88\right)$

${ }^{d}$ rho is the ${ }^{206} \mathrm{~Pb} /{ }^{238} \mathrm{U} /{ }^{207} \mathrm{~Pb} /{ }^{235} \mathrm{U}$ error correlation coefficient.

* corrected for common $\mathrm{Pb}$ using Stacy and Kramers (1975) model Pb composition

${ }^{e}$ Accuracy and reproducibilty was checked by repeated analyses $(n=8)$ of reference zircon BB-16 and Plesovice, Manangotry monazite and Bear lake titanite; data given as mean with

2 standard deviation uncertainties 